Historic, Archive Document

Do not assume content reflects current scientific knowledge, policies, or practices. 



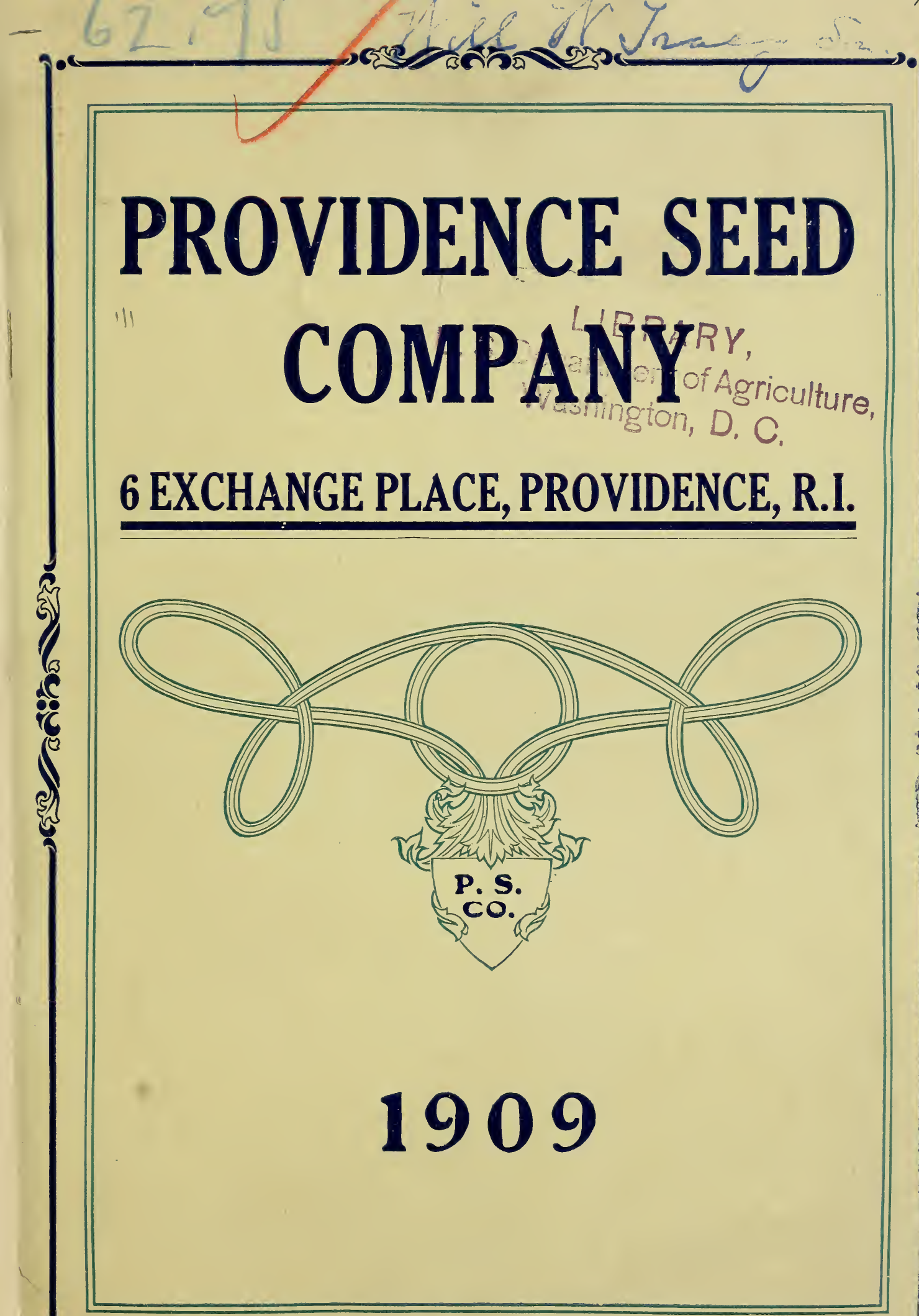

1909 


\section{VALUABLE TABLES.}

\section{SEED REQUISITE TO PRODUCE A GIVEN NUMBER OF PLANTS AND SOW AN ACRE.}

Asparagus, I Oz. to 200 plants

Barley

Beans, Dwarf, I qt. to Ioo feet of drill

Beans, Pole, I qt. to 200 hills

Beet, Garden, I oz. to 50 feet of drill .

Beet, Mangel, I oz. to 50 feet of drill .

Broccoli, I oz. to I, 500 plants

Brussels Sprouts, I oz. to I, 200 plants

Buckwheat

Cabbage, I oz. to 2,500 plants

Carrot, I oz. to Ioo feet of drill.

Cauliflower, I oz. to 2,500 plants

Celery, I oz. to 3,00o plants

Clover, Alsike and White Dutch

Clover, Lucerne, large Red, Crimson \& Trefoil I

Clover, Medium

Corn, Sweet, I qt. to 200 hills

Cress, I oz. to Ioo feet of drill

Cucumber, I oz. to 50 hills

Egg Plant, I oz. to I,ooo plants

Endive, I oz. to I 50 feet of drill

Gourd, I oz. to 25 hills

Grass, Timothy .

Grass, Red Top, chaff

Grass, Red Top, recleaned .

Grass, Orchard

Grass, Kentucky Blue

Grass, Rhode Island Bent .

Grass, Perennial Rye

Kale, I oz. to $\mathbf{I , 2 0 0}$ plants .
Quantity per acre

5 1bs.

$21 / 2 \mathrm{bu}$.

I $1 / 4$ " "

$1 / 2$ "

$61 \mathrm{bs}$.

8 "

8 oz.

8 "

I bu.

$5 \mathrm{oz}$.

4 1bs.

5 oz.

4 “"

I 5 1bs.

5

5

8 qts.

8 1bs.

5 ib.

3 lbs.

$2 \frac{1}{4}$

$1 / 2$, bu.

3 “

$201 \mathrm{bs}$.

$3 \mathrm{bu}$.

3 "

3 "

$601 \mathrm{bs}$.

$6 \mathrm{oz}$.
Kohl Rabi, I oz. to I 50 feet of drill

Leek, I oz. to I oo feet of drill

Lettuce, I oz. to 250 feet of drill

Martynia, I oz. to 50 feet of drill

Melon, Musk, I oz. to 60 hills

Melon, Water, I oz. to 40 hills.

Nasturtium, I oz. to I 5 feet of drill.

Oats.

Okra, I oz. to 40 feet of drill

Onion Seed, I oz. to Ioo feet of drill.

Onion Seed, for Sets .

Onion Sets, r qt. to 20 feet of drill

Parsnip, I oz. to roo feet of drill

Parsley, I oz. to I 50 feet of drill

Peas, Garden, I qt. to roo feet of drill

Peas, Field .

Pepper, I oz. to 2,00o plants

Potatoes

Pumpkin, I qt. to 300 hills

Radish, I oz. to roo feet of drill .

Rye

Salsify, I oz. to 50 feet of drill

Spinach, I oz. to 50 feet of drill

Summer Savory, I oz. to 500 feet of drill

Squash, Summer, I oz. to 40 hills

Squash, Winter, I oz. to 20 hills

Tomato, I oz. to 2,00o plants

Tobacco, I oz. to 4 ,ooo plants

Turnip, I oz. to I 50 feet of drill
Quantity per acre

$21 \mathrm{bs}$

4 "

3 “

I0 "

2 "

$3^{6}$

Io "

$3 \mathrm{bu}$.

Io 1 bs.

4 to 5 "

30 to 50 "

8 bu.

$5 \mathrm{lbs}$.

8 “

$\mathrm{I} / 2 \mathrm{bu}$.

$2 \frac{1}{2}$ "

4 oz.

Io bu.

4 qts.

8 1bs.

$\mathrm{I} / 2 \mathrm{bu}$.

Io $1 \mathrm{bs}$.

IO "

2 “

2 "

4 “

3 oz.

2 "

2 lbs.

\section{WEIGHT OF VARIOUS ARTICLES.}

\section{Barley}

Beans

Buckwheat

Blue Grass, Kentucky

Canary Seed

Castor Beans

Clover Seed

Corn, Shelled

Corn on Far

Corn Meal.

Hemp Seed

Hungarian Grass Seed

Irish Potatoes, heaping measurs Millet

Oats
Per bush., 48 1bs.

\begin{tabular}{|c|c|}
\hline \&6 & 60 " \\
\hline “6 & 48 '، \\
\hline "6 & 14 " \\
\hline 66 & $60 "$ " \\
\hline " & $46 ،$ \\
\hline " & $60 "$ \\
\hline " & $5^{6}$ ، \\
\hline 16 & " \\
\hline " & 50 " \\
\hline " & 40 " \\
\hline " & 48 “ \\
\hline "6 & $60 "$ " \\
\hline “" & $50 "$ " \\
\hline " & 32 " \\
\hline
\end{tabular}

\section{Orchard Grass}

Onions

Peas

Rape

Rye.

Red Top Seed, Chaff Seed

Red Top Fancy, Clean Seed

Timothy Seed.

Turnips

Wheat

Corn on Cob, in bin

Corn, Shelled, in bin

Wheat, in bin.

Oats, in bin

Potatoes, in bin
Per bush., I4 1bs.

$\begin{array}{ll}\text { " } & 52 \\ \text { " } & 60 \\ \text { " } & 50 \\ \text { " } & 56 \\ \text { " } & 40 \\ \text { " } & 45 \\ & 60\end{array}$

Per cubic foot, 22

$\begin{array}{lll}\text { " } & 45 & \\ \text { " } & 48 & \\ \text { " } & 251 / 2 & \text { " } \\ & 60 & \end{array}$




\section{PROVIDENCE \\ SEED COMPANY'S}

CATALOGUE OF

\section{SEEDS AND IMPLEMENTS BULBS, PLANTS AND FERTILIZERS}

POULTRY SUPPLIES

GREENHOUSE SUPPLIES

I 909

PROVIDENCE SEED COMPANY (THE FIRM THAT IS GROWING)

6 EXCHANGE PLACE, PROVIDENCE, RHODE ISLAND (OPPOSITE THE NEW POST OFFICE) 


\section{9}

Thirtieth Year

To Our Customers :

It is with great pleasure that we announce the fact that our business is stea lily increasing, which shows that our efforts to supply only the Best Seeds are appreciated both by the large and small planter. Reliability is ever our watchword.

Our seeds cost a little more than do usual commercial grades, - but they are worth much more. The steady growth of our business is due, in a large degree, to the recommendations of our regular customers, to whom we return our hearty thanks. If you are not already one of our customers, try us and be convinced that we sell only the Best Seeds, as well as other goods of the highest quality.

\section{PROVIDENCE SEED COMPANY}

Seeds by Mail. All seeds ordered at ounce, package and one-quarter poun $!$ rates are sent by mail prepaid. All seeds in bulk from four ounces and up, postage to the amount of eight cents per pound must be added to our Catalogue prices. All heavy seeds, such as Peas, Beans, Corn, Seed Grain, Roots, Etc., we do not send free, as such are quoted at net prices at our store.

Seeds in Packets. All Vegetable Seeds, except Peas, Beans and Corn, are supplied at five cents per packet unless otherwise noted.

Seeds by Weight. We supply one-half pounds and over at pound rates; less than one-half pound lots are charged at one-quarter pound rates; less than onequarter pourd lots at ounce rates. The smallest quantity of flower seed we weigh is ten cents value.

Bags Used in Packing are charged at the following rates: one-quarter and one-half bushel at ten cents each; one bushel at fifteen cents each; two bushel at twenty cents each. If returned within sixty days, sound and in good condition, free of expense, the above prices will be refunded.

Our Annual Illustrated Catalogue of Bulbs for Fall Planting will be issued in September and mailed to our customers. We import these Bulbs from some of the oidest and most reliable growers in France and Holland, and customers entrusting us with their orders will find them equal to those sold by any reputable house.

While we exercise the greatest care to have all seeds pure and reliable, we do not give any warranty, expressed or implied. If the purchaser does not accept the Seeds on these terms and conditions, they must be returned at once, and the money that has been paid for same will be refunded.

Poultry Supplies. After several years of earnest labor, we are now recognized as one of the foremost dealers in Poultry Supplies in New England. We would be pleased to mail a copy of our Poultry Supply Catalogue for the asking.

We have added some articles since our last catalogue was published, and while our line of Poultry Supplies is not the longest line, it is made up of carefully selected articles of "standard quality" — the best on the market to-day. 


\section{Vegetable Seeds.}

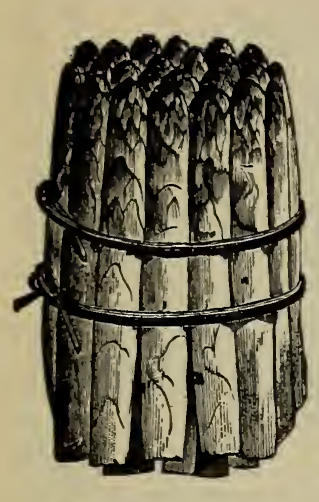

ASPARAGUS.

Sow in spring as early as the ground can be worked, in drills one foot apart, covering the seed one inch deep. Thin the plants to three inches in the rows. Cultivate during summer, and give the plants a light covering of stable-litter during winter. When two years old they may be transplanted into permanent beds, setting the plants four inches beneath the surface, in rows two feet apart, and the plants one foot apart in the rows. The soil should be well trenched and highly manured to insure a good crop.

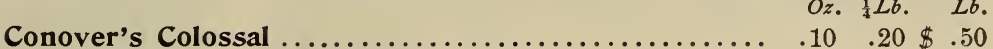

Palmetto...................................

\section{ASPARAGUS ROOTS.}

Conover's Colossal. Two years old $\ldots \ldots \ldots \ldots \ldots \ldots \ldots, \$ 5.00 \quad .60$

Palmetto. Strong, two years old............... $6.00 \quad 75$

\section{BEANS-Dwarf or Bush.}

A succession of sowings can be made from the first week in May until September. Plant in rows eighteen inches apart and two inches deep, according to the richness of the soil. A11 the following varieties of beans are very sensitive to frost and cold. Hoe only when dry, as the scattering of earth on the foliage or pods when moist will cause them to become damaged with rust.

\section{GREEN SNAP VARIETIES.}

Early Red Valentine. An excellent string bean.................... 2 .

Early Mohawk. Early, hardy, productive, and of rich flavor..............25

Early Yellow Six Weeks. Very early, popular string bean $\ldots \ldots \ldots \ldots \ldots \ldots . .25$

Refugee. Extremely early, round pod, very tender $\ldots \ldots \ldots \ldots \ldots \ldots \ldots \ldots . .25$

Burpee's Stringless Green Pod. Extra early, stringless and very prolific;

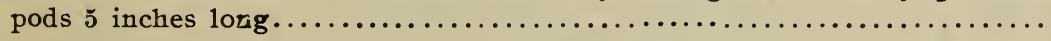

\section{SHELL VARIETIES.}

Dwarf Horticultural. The most popular variety; very early............ .25

Low's Champion. Excellent string or shell bean; early .............. .25

Goddard, or Boston Favorite. An improved variety of Dwarf Horticultural..

Bountiful. Extra early; prolific; flat green pods, tender and stringless........

\section{WAX OR BUTTER VARIETIES.}

Rust=Proof Golden Wax. The standard variety for general use; pods long and

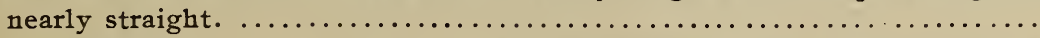

Wardwell's Kidney Wax. Pods flat, very long and nearly straight; one of the

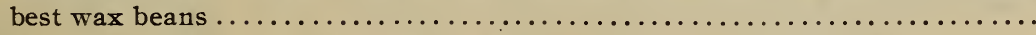

Davis' White Wax. Large, handsome, straight pods, 5 to 6 inches long; im-

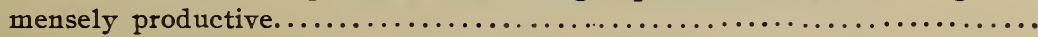

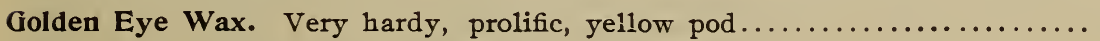

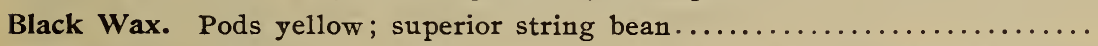




\section{BEANS - Pole or Running.}

These are more tender and require more care in culture than the Bush Beans, and should be sown two weeks later than those. Plant in hills about three feet a part, putting four or five beans in a hill, and leaving a space in the centre for the pole. They succeed best in sandy loam, which should be liberally enriched with short manure in the hills. Lima and Sieva Beans will not grow until the weather and ground are warm.

Pole Horticultural. A popular variety for private garden use............. .30 $\$ .85$

Large Lima. One of the finest of all pole beans . . . . . . . . . . . . . . . . . . .

Sieva, or Small Lima. Earlier and hardier than the large Lima............ $.30 \quad 1.00$

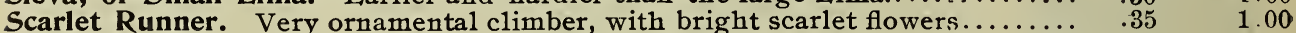

White Runner. Similar to preceding, except flowers are white........... $\quad .35 \quad 1.00$

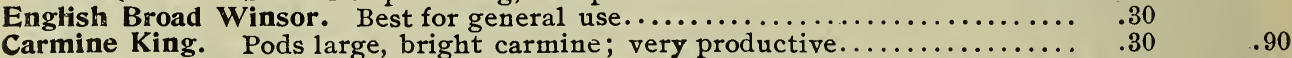

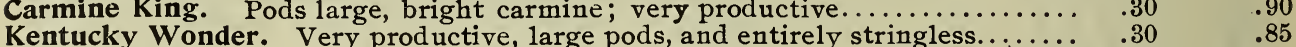

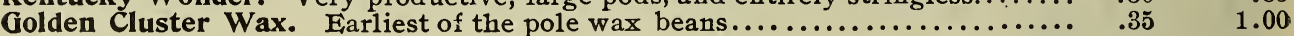

\section{BEETS.}

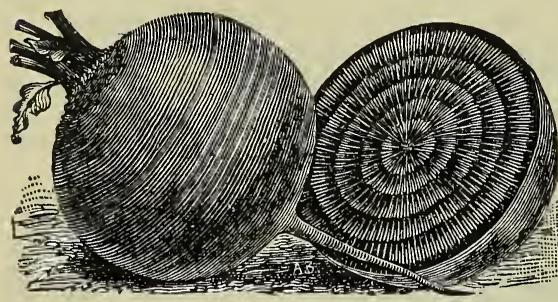

The soil which is best suited for the culture of the Beet is that which is rather light than otherwise, always provided it is thoroughly enriched with manure. For an early supply sow in spring, as soon as the ground becomes fit to work, in drills, about one foot a part and two inches deep. For main crop sow early in May, and for winter use sow in June. Thin out to six inches apart and hoe frequently. In October the roots may be taken up and stored in cellar, or in pits outside, like potatoes, care being taken that they are not bruised or injured in the process.

$O z \cdot \frac{1}{4} L b . \quad L b$.

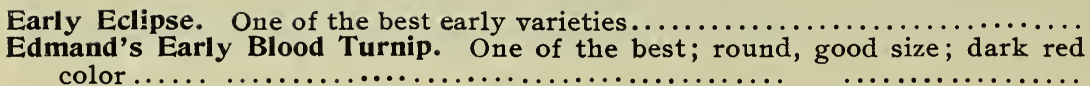

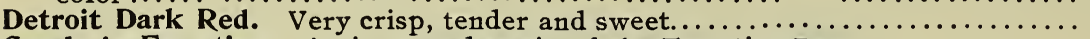

Crosby's Egyptian. An improved strain of the Egyptian Bee ${ }^{\dagger} \ldots \ldots \ldots \ldots \ldots \ldots \ldots$

Long Smooth Blood. An excellent late variety . . . . . . . . . . . . . . . . . .

Crimson Globe. The flesh and skin are very dark ; second early . .............

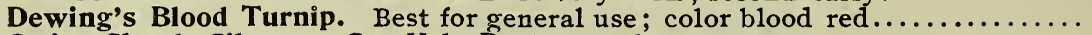

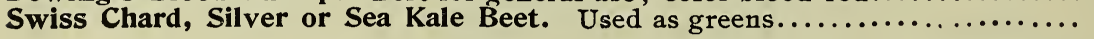

$\begin{array}{lll}.10 & .20 & .60 \\ & & \\ .10 & .20 & .60 \\ .10 & .20 & .60 \\ .10 & .25 & .75 \\ .10 & .20 & .60 \\ .10 & .20 & .60 \\ .10 & .20 & .50 \\ .10 & .25 & .75\end{array}$

\section{SUGAR BEETS AND MANGEL WURZEL.}

Mammoth Long Red. One of the best varieties; heavy cropper.............

Norbiton Giant Long Red. This is a valuable variety for deep soil. . . . . . . .

Golden Tankard. Bright golden yellow; sweet flavor.......................

White French Sugar Beet. A well-known variety for feeding stock...........

$\begin{array}{ll}O z . & L b . \\ .05 & .40 \\ .05 & .40 \\ .05 & .40 \\ .05 & .40\end{array}$

\section{BORECOLE, OR KALE.}

Sow early in spring in prepared beds, covering the seed thinly and evenly, transplant in June, and treat in the same manner as for Cabbage. The following varieties are extremely hardy, and are best when touched by frost.

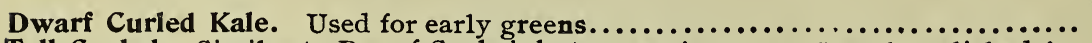
Oz. $\quad L b$. Lb. Tall Curled. Similar to Dwarf Curled, but more vigorous. Greatly relished by

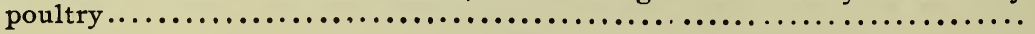

$.15 \quad .35 \$ 1.00$ $.10 \quad .30 \quad 1.00$

\section{BROCCOLI.}

Nearly allied to the Cauliflower, but more hardy. The seed should be sown in May, in a seed-bed, and the plants afterwards set in rows about two and a half feet apart, leaving eighteen inches between the plants. It succeeds best in a moist and rather cool atmosphere.

Purple Cape. Heads greenish purple; hardy and popular variety............. $\begin{array}{ccc}\text { Pkt. } & { }_{.10} \text {. } & .30\end{array}$ White Cape. Heads white.......................................... $.10 \quad .30$

\section{BRUSSELS SPROUTS.}

The plant grows two or three feet high, and produces from the side of the stalk numerous little sprouts one or two inches in diameter, resembling cabbages. Sow in hotbeds in March or A pril, and in the open ground in May. Transplant and cultivate like the cabbage.

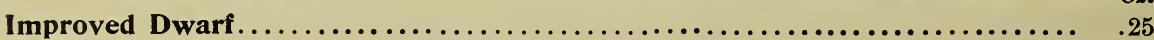




\section{CABBAGE.}

For early crops sow in hotbed in February and March. When the plants are four or five inches high, they should be transplanted in the open air as soon as the soil will admit, in rows two feet apart, and about fifteen inches from plant to plant. Late varieties are usually sown in the middle of May, and the plants are set out in July at distances of three feet between the rows, and about twenty inches from plant to plant.

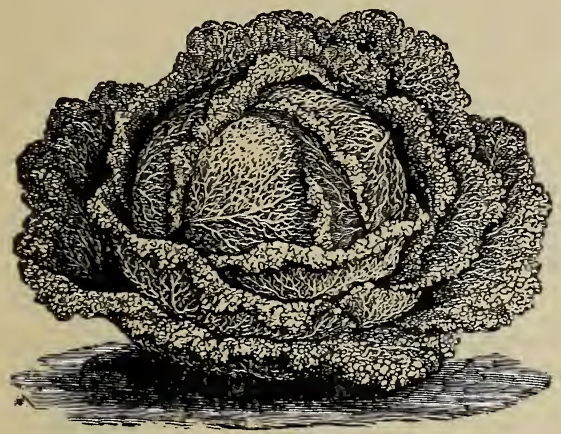

All=Seasons. Early ; heads large and

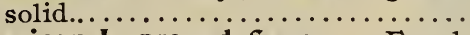
American Improved Savoy. Excellent sort for market gardeners....

Charleston Wakefield. Larger than the Jersey, but not quite as early..

Early Jersey Wakefield. The best and most profitable variety; very

Early York. Very early; tender and

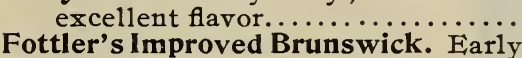
Drumhead, very large, and is equally valuable as a winter cab-

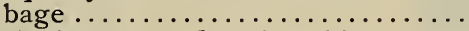

Henderson's Early Summer. Extra stock; the best second early cabbage..... Danish Ballhead. Heads are thick, round, of medium size and very hard...... Marblehead Mammoth. A late variety; the largest of all cabbages ..........

Premium Flat Dutch. Large and excellent for winter. .................

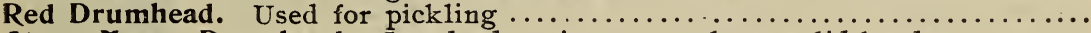

Stone Mason Drumhead. Standard variety; very large solid heads...........

Succession. A second early, with large solid heads . . . . . . . . . . . . . . .

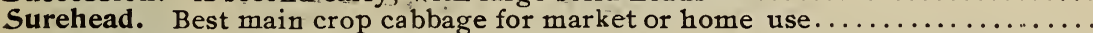

Winningstadt. A fine variety for general use $\ldots \ldots \ldots \ldots \ldots \ldots \ldots \ldots \ldots \ldots \ldots$

$O z$

$.25 \quad .75$

$.25 \quad .75$

$.25 \quad .75$

.25

.20

Our Cabbage Seed is grown for us on Long Island.

\section{CARDOON.}

Grown for the mid-ribs of the leaves, which are blanched in the same manner as celery.

Pkt. Oz. Lb.

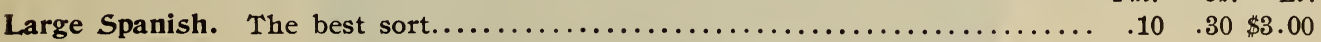

\section{CARROT.}

For early crop, sow as soon as the ground can be worked; they may be sown as late as the middle of June; the drills should be one inch deep and one foot apart, thinning out to three or four inches between the plants. Carrots do best in a deeply tilled, sandy loam.

Early Scarlet Horn. A favorite sort; for early summer use. Oz., .10; $1 / 4$ 1b., .25; 1b., 80 .

Early French Forcing. The earliest variety grown ; small, tender, fine quality. Oz., .10; $1 / 41 \mathrm{~b} ., .25 ; 1 \mathrm{~b} ., .80$.

St. Valery Grows from ten to twelve inches long. Oz., .10; 1/4 1b., .25; 1b., .80.

Guerande, or Oxheart. Stunip-rooted ; fine flavor and color. Oz., . $10 ; 1 / 41$ b.. . $25 ; 1$ b., .80 .

Danvers Half Long. Of excellent quality; yields the greatest bulk with the smallest length of root. Oz., $.10 ; 1 / 4$ 1b., .25; 1b., .80.

Chantenay. A stump-rooted variety, having a large shoulder; very productive. Oz., .10; 1/4 1b., .25; 1b., .80.

Improved Long Orange. Large variety; used for main crop. Oz., $.10 ; 1 / 4$ 1b., .20; 1b., .60.

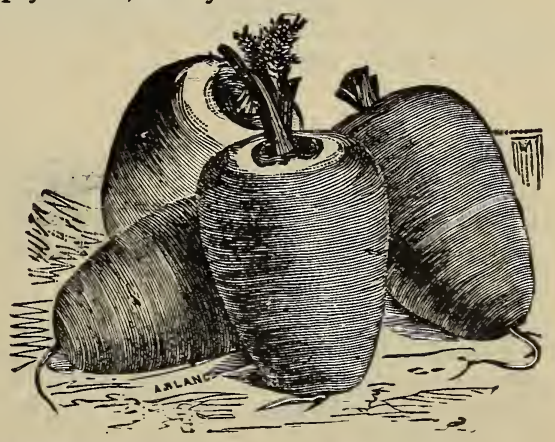

White Belgian. Large white root; extensively grown for stock feeding. Oz., .10; 1/41b.,.20; 1 b.,.60.

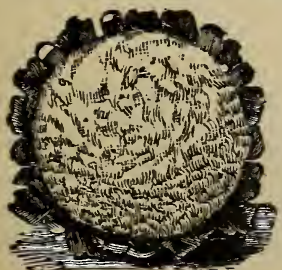

CAULIFLOWER.

Cultivate as directed for cabbage. In dry weather water liberally. Cauliflower likes a cool, moist situation.

Early Dwarf Erfurt. Very earliest variety ...............
Early Snowball. A very popular early variety; for family

Pkt. Oz. use or market gardeners..$\ldots \ldots \ldots \ldots \ldots \ldots \ldots \ldots \ldots$

$\$ 2.50$

$.20 \cdot 2.00$




\section{CELERY.}

Seed may be sown in the open ground in April. Sow about half an inch deep, and firmly press the soil over the seed. After the seed is up, keep carefully clear of weeds until the time of planting in June or July. After the grouud has been well prepared, plant in rows from three to four feet a part, according to the variety, setting the plants about six inches apart and pressing the soil firmly about the roots. The soil best suited for Celery is a rich, moist loam.

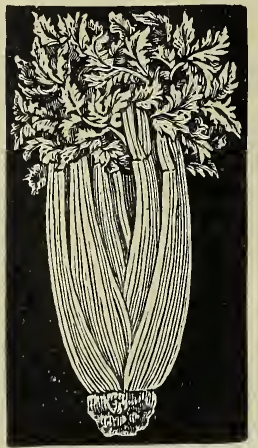

Paris=Golden Self=Blanching. True. The best celery for early market use; very large, crisp and solid. Pkt.. .10 ................................

Giant Pascal. Of excellent flavor; very large and

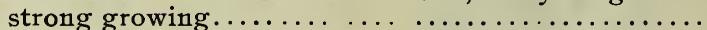

Boston Market. True Stock; the most popular variety

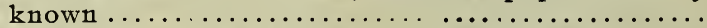

White Plume. The best variety for early use..........

Pink Plume. Best of all the red or pink varieties; very

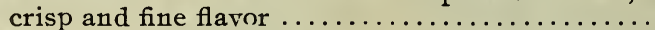

$\frac{1}{4} L b$.

Celeriac, or Turnip Rooted. Grown exclusively for its roots, which are used when cooked in salads, etc....

Soup Celery. Used for flavoring, lb., .40............

.40

$\$ 1.25$

.25

.30

.25

.25

.25

.05
.75

1.00

.75

.75

.85

.15

\section{CHERVIL.}

Cultivated the same as parsley. Used for flavoring soups and stews. The tops only are used.

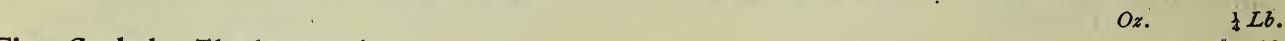
Fine Curled. The best variety................................ .20 $\$ .60$

\section{CHICORY.}

The leaves are used as salads, either in their natural state or blanched, with oil and vinegar.

Large Rooted Magdeburgh Whitloof. $\mathrm{Oz}$. $\frac{1}{4} L b$. Large Rooted Brussels or Whitloof

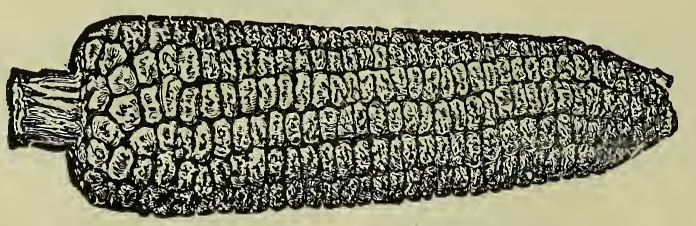

\section{CORN - Sweet.}

Plant for a succession of crops every three weeks, from April to July, in hills three feet apart each way, six seeds in a hill; cover about an inch; thin to three plants. Corn does best in a warm and rich soil.

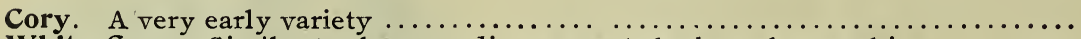

White Cory. Similar to the preceding, except the kernels are white ...........

Golden Bantam. Bright golden yellow ears ; very early and sweet .............

Peep o' Day. Two to four ears on each stalk; delicious flavor and early.........

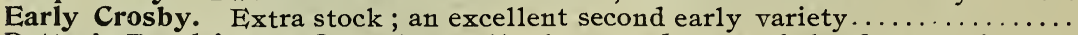

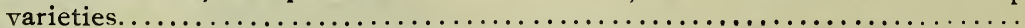

Black Mexican. One of the most desirable for family use; very tender and sweet

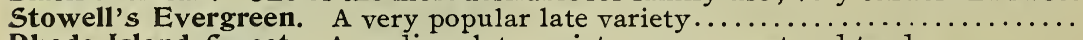

Rhode Island $S$ weet. A medium late variety; very sweet and tender .............

Country Gentleman. Medium late variety. The sweetest and most tender of

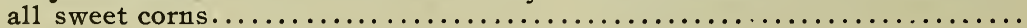

\section{FODDER AND FIELD CORN.}

Sweet Fodder. For cutting green and feeding to stock................... White Ensilage. Excellent for fodder and ensilaging purposes.................. Rhode Island White Cap. A well-known" small, white flint variety............ Angel of Midnight. Early yellow field corn; very productive $\ldots . . . \ldots \ldots \ldots \ldots .$. Improved Canada Yellow. It will mature in ninety days from planting........ Longfellow. One of the best for main crop; very long ears.................. Leaming. Dented flint variety, large ears, nearly as early as the Canada........ 2t.

\section{.25}

.25

.30

.30

.25

.25

$2 t$.

$\frac{1}{2} \mathbf{P k}$.

.25

.25

.30

$P k$.

Market Price Market Price

$.60 \$ 2.00$

$.60 \quad 2.00$

$.60 \quad 2.00$

$.60 \quad 2.00$

$.60 \quad 2.00$ 


\section{CORN SALAD, OR FETTICUS.}

Used as a salad. Is sown in early spring, in rows a foot apart, and is fit for use in six or eight weeks from the time of sowing.

Large Leaved.

$O z . \frac{1}{4} L b . \quad L b$.

\section{CRESS, OR PEPPER GRASS.}

A well-known pungent salad; cover very slightly, sow at frequent intervals to keep up a succession; to be used before the flowers appear.

Extra Curled. Very fine, may be cut two or three times................... $.10 .20 \$ .50$

Water Cress. Hardy, perennial aquatic plant..................... $.40 \quad 1.25 \quad 4.00$

\section{CUCUMBER.}

Cucumbers succeed best in warm, rich, sandy loam ground. Plant when all danger of frost is past, in hills about four feet apart each way; the hills should be previously prepared by mixing thoroughly with the soil of each a shovelful of well rotted manure; sow for pickling from the middle of June to the middle of July.

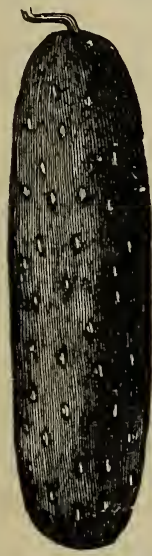

Improved White Spine. One of the best varieties for table use.

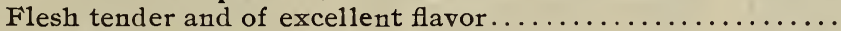

White Spine Forcing. A special strain for cultivation under glass. Fruit grows very even in size; color, dark green......

$O z .+1 L b . \quad L b$.

$.10 \quad .30 \$ 1.00$

Early Russian. The earliest in cultivation; small and pro-

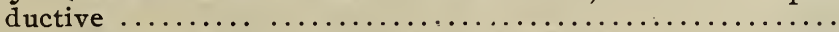

Early Cluster. Length about five inches ; tender and productive

Early Frame. A standard early sort of medium size...........

Boston Pickling. True Stock; the best variety for pickling.....

White Pearl. Very productive, and fine flavor; fruit pearly

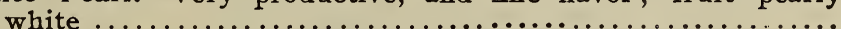

Cool and Crisp. Larger than the White Spine; very early....... Long Green. Ten to twelve inches in length; dark green....... West India Gherkin. Small oval shaped, for pickling ......... Nichol's Medium Green. Unequalled for forcing or pickling.... Everbearing. Small sized, very early, and enormously productive Japanese Climbing. Can be grown either as an ordinary ridge

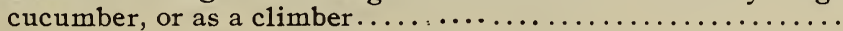

$.301 .00 \quad 4.00$

$\begin{array}{lll}.10 & .30 & 1.00\end{array}$

$\begin{array}{lll}.10 & .30 & 1.00\end{array}$

$\begin{array}{lll}10 & .30 & 1.00\end{array}$

$\begin{array}{lll}.10 & .30 & 1.00\end{array}$

$.15 \quad .30 \quad 1.00$

$.10 \quad .30 \quad 1.00$

$\begin{array}{lll}10 & .30 & 1.00\end{array}$

20

$\begin{array}{lll}10 & .30 & 1.00\end{array}$

$.10 \quad .30 \quad 1.00$

$.10 \quad .30 \quad 1.00$

\section{ENGLISH FRAME OR FORCING CUCUMBERS.}

The following are the best varieties of these well-known Cucumbers, which bear fruit measuring from twenty to thirty inches:

Duke of Edinburgh ; Rollisson's Telegraph ; Triumph. Each, per pkt., .25.

\section{DANDELION.}

Sow in May or June, in drills a foot apart; press the earth firmly over the seed; cultivate during summer; cover lightly with straw during winter, and the following spring the leaves will be fit to cut. The roots when dried and roasted are often employed as a substitute for coffee.

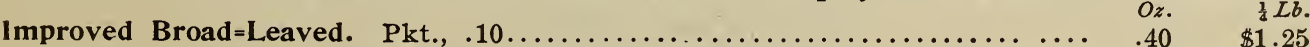

\section{EGG-PLANT.}

The seed should be sown in hotbeds the first week in April. Plant out about June 1st, about two and a half feet apart. The Egg-Plant will thrive well in any good garden soil.

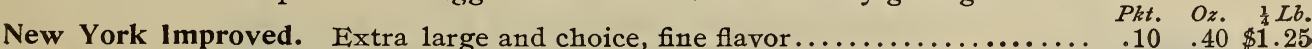
Long Purple. Longer and smaller than above............................ $\quad .10 \quad .30 \quad .85$

\section{ENDIVE.}

Sow in drills one foot apart; thin out to ten inches apart; blanch when the leaves are about nine inches long by drawing them together and tying them carefully.

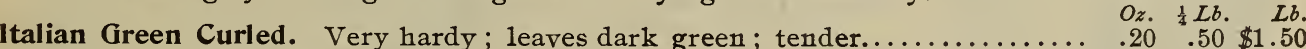
Batavian. Broad-leaved. Leaves long and broad; chiefly used in soups.........20 $.50 \$ 1.50$

\section{KALE-See Borecole. \\ KOHL-RABI.}

The seeds of this plant may be sown at the same period as the Swedish or Rutabaga Turnip, and may be cultivated in the same way, remembering to leave the chief part of the stems uncovered by the earth. The bulbs may be kept sound and nutritious until late in the spring, even later than those of Turnips.

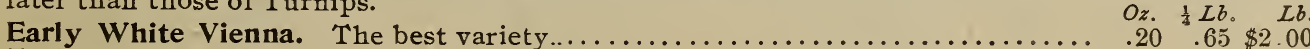

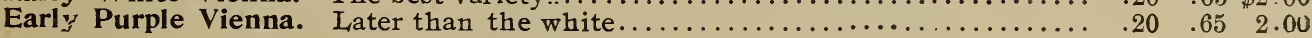




\section{LEEK.}

The Leek is very hardy and easily cultivated. Sow in April in drills one foot apart, and transplant in July into rows fifteen inches apart, and six inches from each other in the rows; the soil should be rich but not fresh manured.

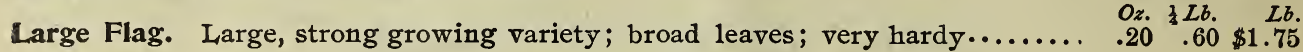

\section{LETTUCE.}

The earliest sowing may be made in February or March, under glass, with slight heat. For later supplies, sow in the open ground as the season will permit; thin out well, and set in rows two feet apart, and a foot between the plants. I,ettuce requires good ground and abundant moisture.

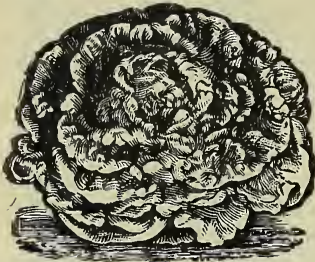

Forcing Tennisball, White Seeded. Selected Stock. $O z$.

$\$ L b$. This lettuce is especially adapted for growing in greenhouses and hotbeds................... Tennisball, White Seeded. Very early and tender.. Black Seeded Tennisball. Excellent for spring crops Boston Curled. A very popular market variety..... All the Year Round. An excellent summer lettuce Henderson's New York. Large and solid head; tender, and of excellent flavor ...................

Hanson. Large variety ; crisp and tender; stand summer heat we11............ Early Curled Silesia. An early variety of very strong growth $\ldots . . . \ldots \ldots . .$. Crumpled Leaf. For greenhouse and hotbeds; heads large and very tender. Pkt. .io Black Seeded Simpson. An improved variety of the ordinary Curled Simpson Grand Rapids. Large, tender, one of the best for early forcing . . . . . . . . . . . .

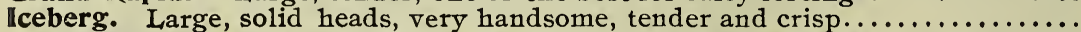

Paris White Cos. An upright variety, with long narrow leaves; requires tying

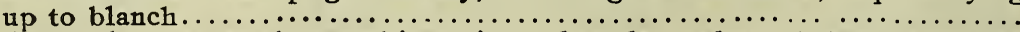

Tomhannock. Leaves almost white, crisp and tender; edges of the outer leaves

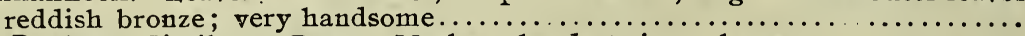

Big Boston. Similar to Boston Market; heads twice as large.................

Denver Market. For forcing or open ground culture; heads large and solid; leaves blistered like a Savoy Cabbage; very crisp and tender...............

Sensation. Good for either forcing under glass, or growing out of doors; solid

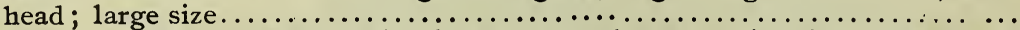

Trianon. Of upright growth, with long, narrow leaves, which form close heads

tLo.

.40

.15

.15

.15

.15

$\$ 1.00$

.50

.50

.50

.50

.15

.50

.50

.50

1.10

.50

.50

.50

.50

.15

.50

.50

.15

.50

.15

.50

.15

.50

\section{MARTYNIA.}

The seed pods are used for pickling, and should be gathered green while tender; sow in the open ground in April or May, and transplant two feet apart.

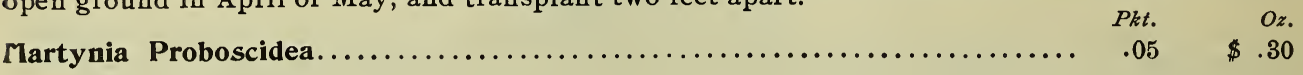

\section{MELON - Musk.}

Prepare hills four to five feet apart each way ; mix well with the soil in each hill a couple of shovelfuls of thoroughly rotted manure. When the weather has become warm, plant from twelve to fifteen seeds in each hill, afterwards thin out, leaving four good plants.

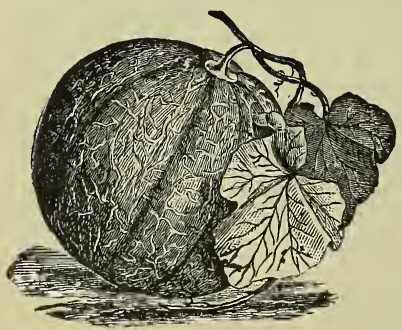

Extra Early Hackensack. Of good size, heavily $O z . \frac{1}{4} L b . \quad L b$. ribbed and netted; thick light green flesh of

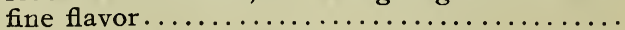

Button. Very early; netted, of small round size; flesh light green; has small button at blossom

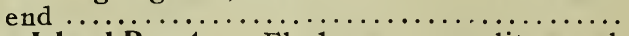

Long Island Beauty. Flesh green; quality excellent; early and deeply netted...............

Emerald Gem. Flesh salmon color; skin deep emerald green; very early................

Rock Ford. The skin is a light golden hue; flesh light green; nearly round or slightly oval...

Paul Rose or Petoskey. Skin light green; the flesh is thick, of rich deep orange

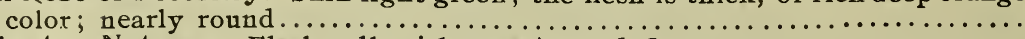

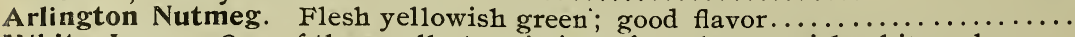
White Japan. One of the smallest varieties, of a pale greenish-white color..... Miller's Cream or Osage. Medium size, oval, dark green skin; salmon color flesh Bay View. Very prolific and of good size; oblong; green flesh............... Banquet. Globe-shaped; densely netted; dark, very rich salmon flesh......... 


\section{MELON - Water.}

Plant in hills as directed for Musk-melons, and treat in all respects the same except that the hills should be about eight feet apart.

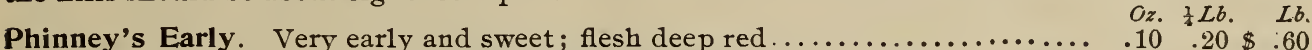

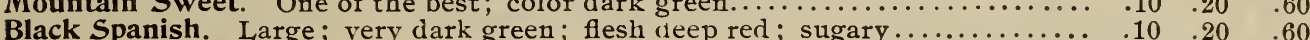

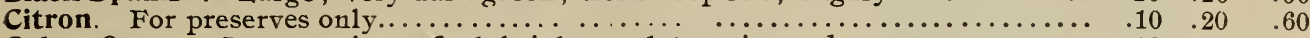

Cuban.Queen. Large variety; flesh bright scarlet; crisp and sweet. . . . . . . . $\quad .10 \quad .20 \quad .60$

Kolb's Gem. Very large size; nearly round; dark green color .............. $\quad .10 \quad .20 \quad .60$

Ice Cream. One of the earliest; nearly round; of pale green color; flesh scar-

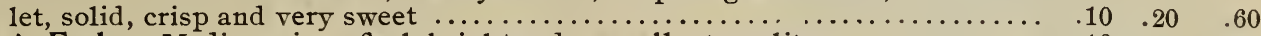

Cole's Early. Medium size ; flesh bright red; excellent quality............ $\quad .10 \quad .20 \quad .60$

\section{MUSHROOM.}

Mushrooms may be grown in a warm cellar or shed in winter, or in the open air in summer. Take partially dry, fresh horse manure and lay it in a heap to ferment; turn and mix it well every few days, and when well and equally fermented, which will be in from ten to fifteen days, it may be made into a bed four feet wide and about two feet deep, mixing it well tngether and beating or treading it firmly. As soon as the temperature of the bed falls from 75 to 50 degrees, the spawn may be inserted in pieces about the size of a walnut, about two inches deep and six inches apart. Cover with loamy soil about two inches deep and beat it down evenly and firmly. Finish off with a covering of cleanstraw or hay about a foot thick. Water when necessary with luke-warm water, and expect mushrooms in from four to six weeks.

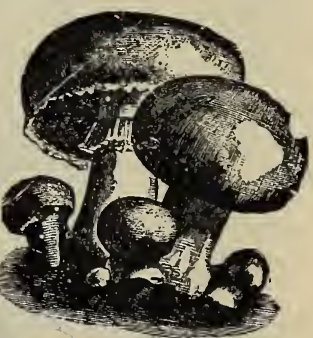

Best English Mill Track ................................Per 1b., .15; 8 lbs. for $\$ 1.00$

MUSTARD.

Sow in shallow drills a foot apart. The young leaves are used for salads, the seeds for flavoring.

White. Best for salads

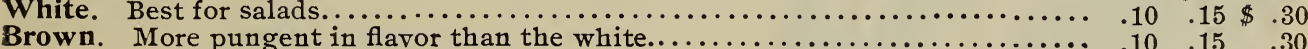

NASTURTIUM.

The seeds while young and succulent are pickled and used as capers. Sow the seeds in drills one inch deep, the tall grown by the side of a fence, or supported by a trellis.

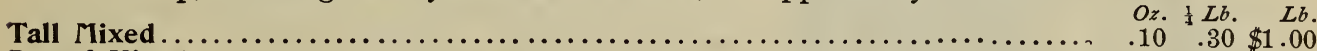

Dwarf Mixed.

\section{OKRA, OR GUMBO.}

Sow early in May, in drills two inches deep, setting the plants from two to three feet apart.

Dwarf Green. The very best variety for general cultivation .............. $O z . \frac{1}{4} L b . \quad L b$.

\section{ONIONS.}

The Onion thrives best in a rather strong, deep, rich, loamy soil, and unlike most vegetables, succeeds well when cultivated on the same ground for successive years. Sow in drills one foot apart, and cover about a quarter of an inch deep, pressed down with the back of a spade. Our stock is all grown from choice selected bulbs, under our own supervision, therefore parties using our seed will be sure of getting new choice seed of the best quality.

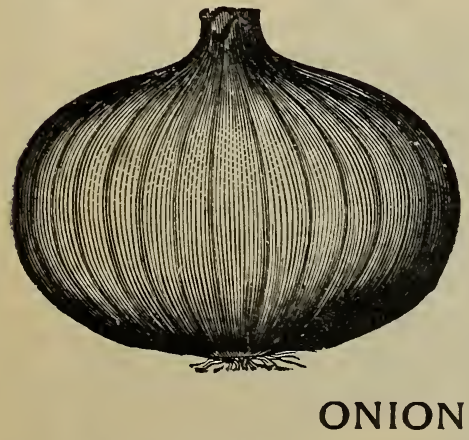

White Oniun Sets. Yellow Onion Sets................. Shallots
Danver's Yellow. Extra selected; best for general use....................

Early Large Red. Very fine early sort; handsome shape..................

Large Red Weathersfield. Grows large and

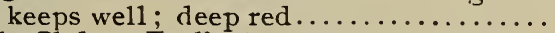

Red Globe, Earliest. Most productive; handsomest of the red sort............

White Globe. An excellent keeper of mild flavor..........................

White Portugal. One of the best for table use ; flavor mild...................

Prizetaker. Large, pale yellow onion; flesh white ; mild flavor.................

$O z . \& L b . \quad L \dot{b}$.

$.20 \quad .60 \$ 2.00$

$.20 \quad .60 \quad 2.00$

$\begin{array}{lll}.20 & .60 & 2.00\end{array}$

$.20 \quad .60 \quad 2.00$

$.20 \quad .75 \quad 2.50$

$\begin{array}{lll}.20 & .75 & 2.50\end{array}$

$.20 \quad .60 \quad 2.00$

\section{SETS. Prices Variable.}

$\begin{array}{rr}2 t . & P k . \\ .25 & \$ 1.25 \\ .25 & 1.25\end{array}$

$.30 \quad 1.25$

Potato Onions

Potato Onions...................

Red Onion Sets.............

2t. $\quad P k$.

$.20 \$ 1.00$

$.25 \quad 1.50$

$.25 \quad 1.25$ 


\section{PARSLEY.}

Sow thickly in drills a foot apart and half an inch deep early in the spring, having soaked the seed in tepid water a few hours.

Champion Moss Curled. Fine and u. $\begin{array}{llll} & \\ \end{array}$ $\begin{array}{lllll}\text { New Fern Leaved. Very ornamental ; valuable for table decoration............ } . .10 \quad .30 & .90\end{array}$

\section{PARSNIP.}

Sow as early as possible, half an inch deep, and press the soil firmly over the seed; succeeds best in a rich, sandy loam.

Hollow Crown or Long Smooth. The standard sort for general use..........

\section{PEAS - Extra Early Varieties.}

For early Peas, the soil should be light, warm and sheltered, but for general crop a moderately heavy soil with liberal dressing of phosphate is better. Avoid fresh manure and wet or mucky soil, they making the vines tall and rank. Plant in drills three or four inches deep, the dwarf varieties two and a half feet, and the tall ones three to four feet apart.

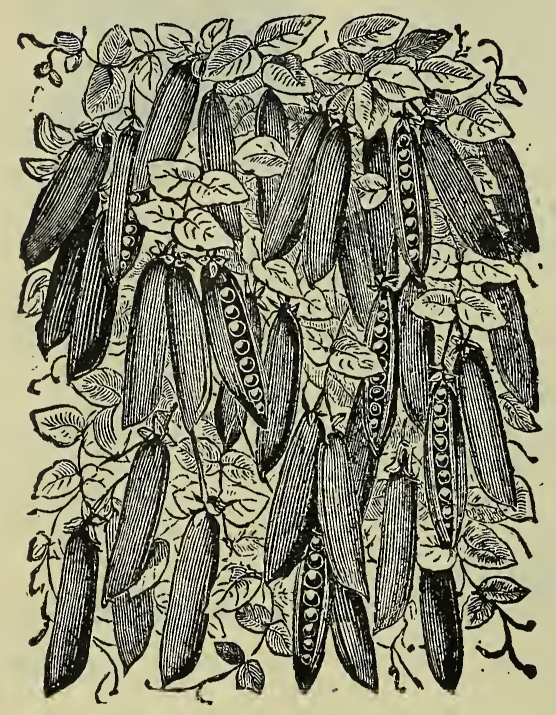

Gradus. The finest extra-early Pea 2. $\quad \frac{1}{2} P k$. yet introduced; the pods are very large and well filled with large wrinkled Peas of the finest variety

Earliest of All or Alaska. A superior blue seeded variety; very early and productire; height two and a half feet..................

$.10 \quad .20 \$ \quad .50$

Bliss's American Wonder. Stands unrivalled; height ten to fifteen

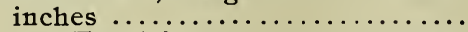

Nott's Excelsior. A grand dwarf wrinkled pea of superb quality; very prolific; height about fifteen inches.$\ldots \ldots \ldots \ldots \ldots \ldots \ldots \ldots \ldots \ldots$

P. S. Co.'s First and Best. One of the first in the market; height two and a half feet..............

Sutton's Excelsior. An early dwarf, wrinkled Pea, with larger pods than any of its class..............

Thomas Laxton. Will mature nearly as early as any of the extra early smooth Peas and being a wrinkled sort is much sweeter. Considered by many superior to the famous

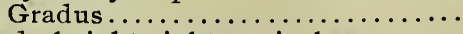

Premium Gem. Early; very prolific; wrinkled; height eighteen inches........

\section{PEAS - Second Early and Later Varieties.}

McLean's Advancer. Dwarf, green wrinkled; height two and a half feet......

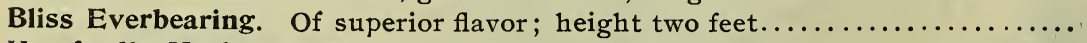
Horsford's Market Garden. Very prolific; superior quality; height two feet..

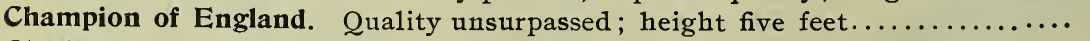

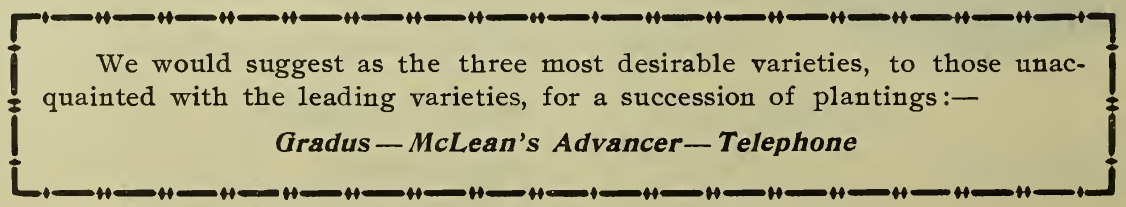




\section{PEPPER.}

Sow the seed in March or April, in a hotbed, and transplant to the open ground as soon as the weather is quite warm, in rows about twenty inches apart, and fifteen inches apart in the rows. A warm, sandy loam is best.

Ruby King. Large and handsome; very mild flavor. Oz., .25; $1 / 4$ 1b., .80 .

Large Bell, or Bull Nose. Early, sweet, and of a pleasant flavor. Oz., .25; $1 / 41$ b., .80.

Squash. Brilliant red ; medium size ; excellent for pickling. Oz., .25; $1 / 4 \mathrm{lb}$., .80.

Sweet Mountain. Larger, sweeter, and milder flavor than the "Bull Nose." Oz., .25; 1/4 1b., .80.

Long Red Cayenne. Pods long, cone-shaped and intensely red. Oz., . $30 ; 1 / 41 \mathrm{~b} ., \$ 1.00$.

Red Cherry. Fruit of a rich, glossy, scarlet color. Oz., .30; $1 / 4$ 1b., $\$ 1.00$.

Chili. Very small, bright red; cone-shaped, best for pepper-sauce. Oz., .30; $1 / 41$ b., $\$ 1.00$.

Golden Dawn. Shaped like the Bell; golden yellow; thick and fine. Oz., .30; $1 / 4$ b., .85.

Chinese Giant. Very long and large; fine scarlet; flesh thick. Oz., .40; $1 / 41 \mathrm{~b} ., \$ 1.50$.

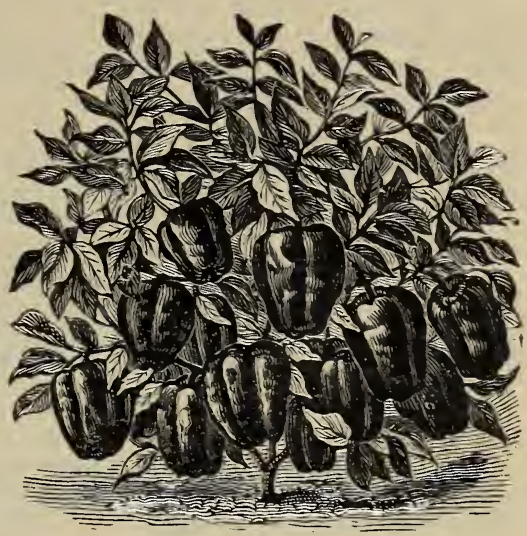

\section{PUMPKIN.}

Pumpkins are now principally cultivated for agricultural purposes. They are usually planted in fields of corn or potatoes, but may profitably be raised in fields by themselres. Sow first of May, in hills eight feet apart.

Yellow Sugar. Very sweet; an excellent table sort........................ $10.20 \$ .50$

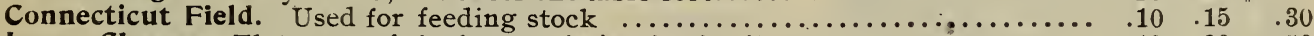

Large Cheese. Flat; one of the best varieties for family use.................$_{10} \quad .20 \quad .50$

Mammoth, Grows to an immense size.................................... $\quad .15 \quad .50 \quad 1.50$

\section{POTATOES.}

\section{Market Prices.}

Plant in hills or rows two feet wide, and one foot apart in the rows. Cover with about two inches of soil, and begin to cultivate when the plants are well up.

Our stock of potatoes is carefully selected direct from the famous Aroostook County, Maine, and comprises the following well-known varieties:

Early Fortune. About ten days earlier than Early Rose.

The Delaware. Medium early; large; skin and flesh white.

Early Harvest. Very early.

Green Mountain. Late; very productive.

New Queen. Early; resembles Beauty of Hebron.
Early Norther. Resembles Early Rose; more productive.

Carman No. 3. Late; greatest yielder ever introduced.

Houlton Early Rose. Description not necessary.

Beauty of Hebron. About one week earlier than Early Rose.

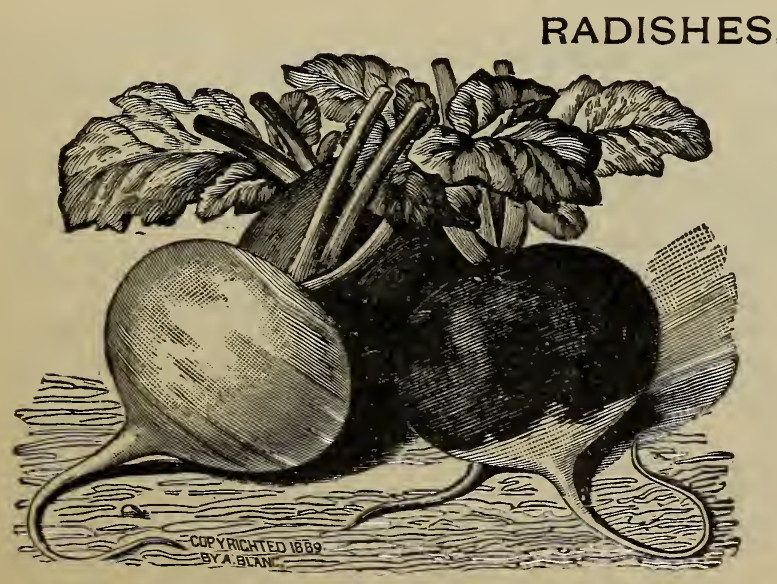

Radishes require a light, rich, sandy soil. For an early supply sow in a hotbed in February, care being taken to give plenty of ventilation. For a successive supply, sow from the middle of March until September, at intervals of two or three weeks.

Long Scarlet Short Top. Standard variety for home and market use. Oz., .10; $1 / 4$ lb., . 20 ; 1b., .60.

Scarlet Turnip. A deep scarlet; early ; fine flavor. Oz., $.10 ; 1 / 4$ b., .20; $1 \mathrm{~b} ., .60$.

Round Scarlet White=Tipped. Very quick growth and excellent flavor. Oz., .10; $1 / 41 \mathrm{~b} ., 20$; 1b. .60.

Crimson Giant. Grows to a large size without becoming pithy. Oz. .10; $1 / 41$ b., $25 ; 1 b ., .75$.

French Breakfast. Scarlet, white tips, oval; quick growing. Oz., .10; 1/4 1b., .20; 1b., .60. 


\section{RADISHES-(Continued.)}

Olive Shaped Scarlet. A good summer variety...

$O z . \quad L b . \quad L b$.

White Strasburg. One of the best of the large summer sorts; roots long and

tapering; skin and flesh pure white; tender, crisp, and fine flavor..........

Black Spanish. Roots oblong; very hardy; for winter use..............

Giant Stuttgart. Very early and grows to a large size; white..............

Early Scarlet Globe. Distinct in shape; brilliant color; fine for forcin; or open ground $\ldots \ldots \ldots \ldots \ldots \ldots \ldots \ldots \ldots \ldots \ldots \ldots \ldots \ldots \ldots \ldots \ldots \ldots \ldots \ldots \ldots \ldots \ldots \ldots \ldots . .10 \quad .25 \quad .75$

White Turnip. Suitable for forcing; pure white; sweet.............. $.10 \quad .20 \quad .60$

\section{SEA KALE.} apart.

Sow one inch deep in drills; thin to six inches; transplant the following spring three feet Sea Kale. The blanched shoots are used like Asparagus; very tender........

$O z$.

.30

\section{SPINACH.}

For summer use, sow early in March, in drills fifteen inches apart, and for succession at intervals of a fortnight. For winter use, sow late in August. The soil should be heavily manured and deeply trenched.

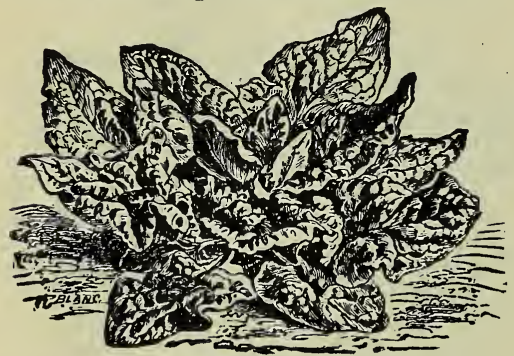

Round Thick Leaved. The best for spring or fall sowing.............

Long Standing. Excellent for spring sowing . ...................

Prickly. The hardiest sort; generally used for fall sowing..............

Bloomsdale. Savoy leaved; for sowing in the fall for early spring use......

New Zealand. Entirely distinct variety; produces a large quantity of leaves; for summer use..................

$O z . \quad \frac{1}{4} L b . \quad L b$.

$.10 \quad .15 \$ \quad .30$

$.10 \quad .15 \quad .30$

$\begin{array}{lll}.10 & .15 & .30\end{array}$

$.10 \quad .15 \quad .30$

$.10 \quad .30 \quad 1.00$

\section{SALSIFY, OR OYSTER PLANT.}

The Salsify has a long, white tapering root resembling a small Parsnip; when properly cooked it has the flavor of an Oyster, and is a good substitute. Sow early, in drills fifteen inches apart; cover the seeds an inch and a half deep.

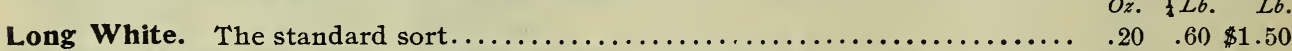

Sandwich Island. Grows to a large size; very mild flavor. $\ldots \ldots \ldots \ldots \ldots \ldots \ldots \ldots \ldots .20 \quad .60 \quad 1.50$

\section{SQUASH.}

The Squash is a very tender vegetable, sensitive of cold, and cannot in our climate be planted before the middle of May. Plant in rich soil, in hills prepared similar to those for Cucumbers. All sorts thinned to not over three plants to a hill.

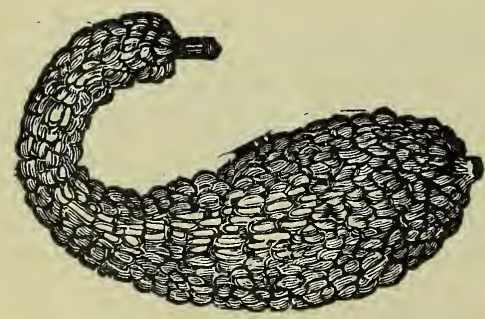

White Bush Scalloped. An early market

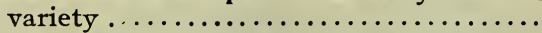

Yellow Bush Scalloped. Much like the white; fruit yellow................

Early Summer Crookneck. The best for

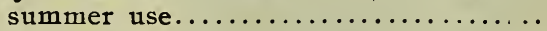

Boston Marrow. A standard winter variety ; a good keeper...............

American Turban. A late variety; flesh

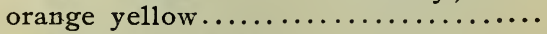

Hubbard. The favorite winter squash; sweet and fine grained..............

Vegetable Marrow. A favorite English sort; flesh white and of rich flavor;

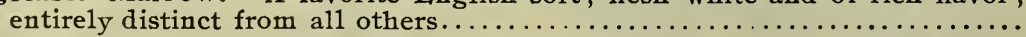

Essex Hybrid. Very rich flavored; fine grained; rapid in growth ; early......

Winter Crookneck. Sweet and fine flavored; a good keeper...............

Golden Hubbard. Earlier than Green Hubbard; shell hard and warty........

Warren. An improved Essex Hybrid $\ldots \ldots \ldots \ldots \ldots \ldots \ldots \ldots \ldots \ldots \ldots \ldots$

$O z . \quad \frac{1}{4} L b . \quad L b$.

$.10 .20 \$ .60$

$.10 \quad .20 \quad .60$

$.10 \quad .20 \quad .60$

$.10 \quad .25 \quad .80$

$\begin{array}{lll}.10 & .25 & .80\end{array}$

$\begin{array}{lll}.10 & .25 & .80\end{array}$

$\begin{array}{lll}.10 & .25 & .80\end{array}$

$\begin{array}{lll}.10 & .25 & .80\end{array}$

$\begin{array}{lll}10 & .20 \quad .60\end{array}$

$.10 \quad .25 \quad .80$

$\begin{array}{lll}10 & .25 \quad .80\end{array}$ 


\section{TOBACCO.}

Sow early as possible when danger of frost is over, in seed bed and cover lightly. When the plants are six inches high transplant into rows six feet apart each way and cultivate thoroughly.

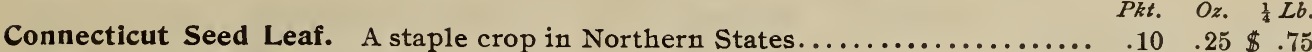
Havana. Choice strain and imported seed ............................... $\quad .10 \quad .30 \quad 1.00$

\section{TOMATO.}

The seed should be sown in a hotbed about the first week in March, in drills five inches apart and half an inch deep. When the plants are about two inches high, set out in boxes three inches deep, four inches a part, in another hotbed, or pot singly. If transplanted a second time will be stocky and branching. When the weather has become mild, transplant into warm, light, rich soil, four feet apart.

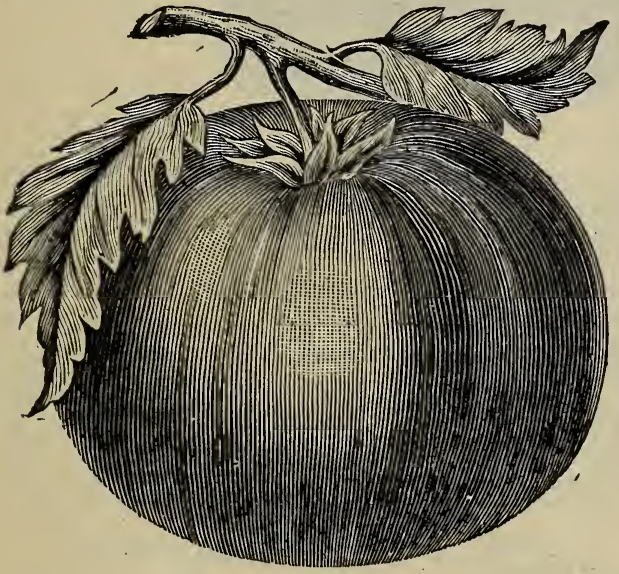

Acme. One of the earliest; perfectly smooth; color, salmon red. Oz., .25; $1 / 4 \mathrm{lb}$., .75.

Aristocrat. Resembles Dwarf Champion in growth; fruit rich, glossy red; very desirable for forcing under glass. Oz., .25; $1 / 4$ 1b., .75.

Crimson Cushion. Brilliant scarlet; very large, solid and smooth. Oz., .40; 1/4 1b., $\$ 1.25$.

Dwarf Stone. The vine resembles Dwarf Champion, the fruits the Stone. Oz., .30; $1 / 4 \mathrm{lb}$., $\$ 1.00$.

Dwarf Champion. A distinct variety; fruit early; medium size; resembling the Acme in size and color. Oz., . $30 ; 1 / 41 \mathrm{~b} ., .85$.

Atlantic Prize. Very early; solid; smooth; excellent quality. Oz., .25; $1 / 1$ 1b., .75.

Earliana. The earliest red tomato ; very smooth. Oz., . 30; $1 / 41 \mathrm{~b} . . \$ 1.00$.

Golden Queen. The finest vellow Tomato in cultivation. Oz., $.30 ; 1 / 41 \mathrm{~b} ., .75$.

Livingston's Beauty. Color, glossy crimson. smooth, firm and solid. Oz., .25; $1 / 41 \mathrm{~b} ., 75$.

Livingston's Favorite. Is one of the largest and most perfect shaped varieties ; ripens evenly; good flavor; flesh solid and smooth; very productive........

Livingston's Perfection. Very large and early; perfectly smooth; blood red

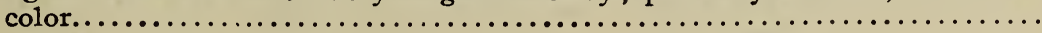

Ponderosa. Very large and smooth ; color, dark rich crimson.................

Red Cherry. Small, round fruit; used for preserves.....................

Stone. One of the best; fruit very large, bright scarlet, very smooth ; ripens

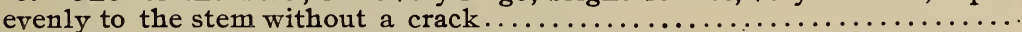

Strawberry. Strawberry-like flavor; excellent for preserves...............

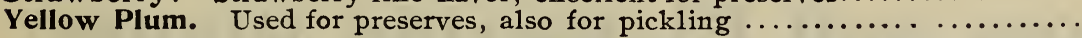

$O z$.

$1<b$.

Our Tomato seed is grown for us by Livingston, the originator of most of the leading varieties.

\section{TURNIP.}

For summer use, sow early in the spring in drills, and thin out to eight inches. For fall and winter, sow from July to September. Rutabagas should be sown in June or early in July, in drills eighteen inches apart; thin out when large enough, six to nine inches apart in the drill, according to size.

Early Flat Dutch. White; of quick growth ; for spring or fall..............

Early Red Top Globe. Remarkable for its heavy yield per acre...............

Early White Milan. Very early; pure white and of fine quality $\ldots \ldots \ldots \ldots \ldots \ldots \ldots . . .6$.

Red Top Strap Leaf. The popular variety for early use..................

White Egg. Smooth and nearly egg-shaped; of rapid growth and fine quality;

excellent fall variety ........................................................
Yellow Aberdeen. Very hardy and productive; globe-shaped, with purple top;

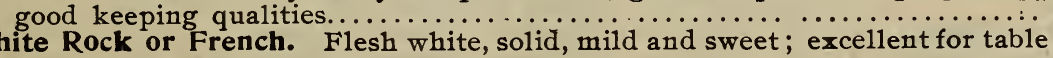

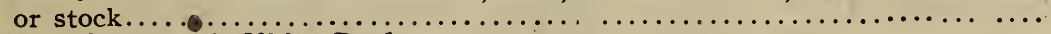

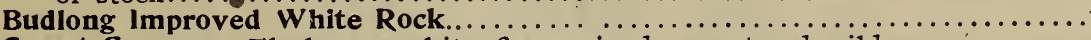

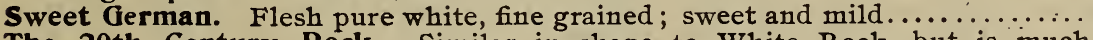

The 20th Century Rock. Similar in shape to White Rock, but is much smoother; matures about three weeks earlier than any other Rock Turnip

Improved American Rutabaga. A yellow-fleshed, purple top variety, grown for

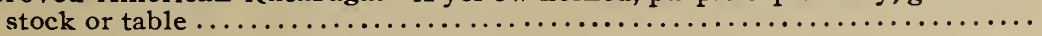

$\begin{array}{ccc}O z . & 1 L b . & L b . \\ .10 & .20 & \$ 50 \\ .10 & .20 & .50 \\ .10 & .30 & .75 \\ .10 & .20 & .50 \\ & & \\ .10 & .20 & .50 \\ & . & \\ .10 & .25 & .50 \\ .10 & .25 & .60 \\ .10 & .20 & .60 \\ .10 & .20 & .50 \\ .10 & .30 & .75 \\ .10 & .20 & .50\end{array}$




\section{SWEET, POT AND MEDICINAL HERBS.}

The cultivation of herbs is very simple, and but little care is needed beyond keeping down the weeds. Sow in April or May, in drills twelve to fifteen inches apart, and thin out the young plants where they stand too thick. Gather when just coming into bloom, tie in small bunches and dry in the shade.

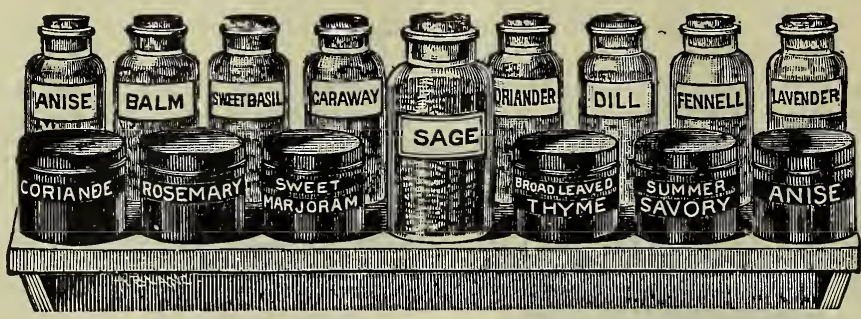

\begin{tabular}{|c|c|c|c|c|}
\hline & Pkt. & $O z$ & & Pkt. \\
\hline Anise & .05 & .10 & Lovage..... & .05 \\
\hline Balm.............................. & .05 & .30 & arjoram, Sweet............... & .05 \\
\hline 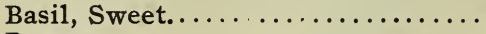 & .05 & .20 & y-Royal........... ..... & .10 \\
\hline e $\ldots \ldots \ldots \ldots \ldots \ldots \ldots \ldots \ldots \ldots \ldots$ & .05 & .1 & lint $\ldots \ldots \ldots \ldots \ldots \ldots \ldots \ldots$ & .25 \\
\hline ( $\ldots \ldots \ldots \ldots \ldots \ldots \ldots \ldots$ & .10 & .40 & emary $\ldots \ldots \ldots \ldots \ldots \ldots \ldots \ldots$ & .05 \\
\hline 1, Curled ................ & .05 & .20 & 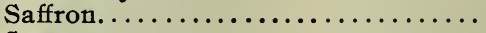 & .05 \\
\hline$\ldots \ldots \ldots \ldots \ldots \ldots \ldots \ldots$ & .05 & .10 & $\ldots \ldots \ldots \ldots \ldots \ldots \ldots$ & .05 \\
\hline$\ldots \ldots \ldots \ldots \ldots \ldots \ldots$ & .05 & .20 & $\ldots \ldots \ldots$ & .05 \\
\hline$\ldots \ldots \ldots$ & .05 & .10 & rel, Large Leaved............. & .05 \\
\hline & .05 & .20 & $\ldots \ldots \ldots \ldots \ldots \ldots \ldots \ldots \ldots$ & .05 \\
\hline & .0 & .20 & $\ldots \ldots \ldots$ & \\
\hline & .05 & .20 & Thyme, Summer................ & .05 \\
\hline
\end{tabular}

Wormwood........................... .05; oz., .30

\section{BIRD SEEDS.}

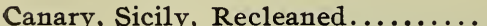

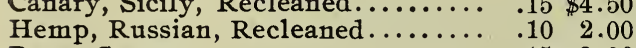

Millet......................... $\quad 2 t$

2t. Bush.

Sunflower.......................... .10 \$2.00

Rape, German .................... .15 300

Unhulled Rice................ .15 3.00

\section{Foliage and Flowering Plants}

\section{FOR SUMMER BEDDING.}

\begin{tabular}{|c|c|c|c|}
\hline & & & \\
\hline geratum. Blue or $w$ & .10 & & \\
\hline le White & .10 & .75 & 5.00 \\
\hline liage & .10 & .75 & 6.00 \\
\hline colors; double & .05 & .25 & 1.50 \\
\hline ers, Double & .05 & .25 & 1.50 \\
\hline nias. & .15 & 1.50 & 10 \\
\hline & .10 & .30 & 2.00 \\
\hline & .15 & 1.50 & 10.00 \\
\hline .. & .10 & 1.00 & 7. \\
\hline • & .1 & .50 & .00 \\
\hline $\mathrm{Fi}$ & .10 & .50 & 3.50 \\
\hline can & .15 & 1.25 & 9.00 \\
\hline & .10 & .50 & 4.00 \\
\hline w. (G & .05 & .50 & 4.00 \\
\hline & .15 & & 10.00 \\
\hline nium, Dot & .15 & & 8.00 \\
\hline ranium, Single. Var & .15 & & 8.0 \\
\hline & & & \\
\hline
\end{tabular}

Heliotropes. Dark and light. Each Doz. Hund.

Lantanas. In variety......... $\quad .10 \quad 1.00 \quad 8.00$ Lobelia. Dark blue,for bedding $\quad .05 \quad .60 \quad 4.00$ $\begin{array}{lllll}\text { Marisold. (Dwarf French).... } & .05 & .50 & 2.00\end{array}$ $\begin{array}{llll}\text { Mignonette. (Large-flowered) } & .05 & .60 & 4.00\end{array}$ Nasturtium, Dwarf. Assorted $\begin{array}{llll}.05 & .50 & 3.00\end{array}$ $\begin{array}{llll}\text { Nicotiana. White, sweet scented } & .10 & .60 & 4.00\end{array}$ Pansy. Special strain, extra choice.................. $.10 \quad .50 \quad 4.00$ Petunia, Double. Ass't'd colors $\quad .15 \quad 1.25 \quad 8.00$ Petunia, Single. Ass't'd colors $\quad .10 \quad .50 \quad 3.00$ Phlox Drummondii. Assorted $.05 \quad .50 \quad 3.00$ Ricinus. Castor oil bean .... Salvia Splendens. Best scarlet $\quad .10 \quad 1.25 \quad 8.00$ Verbenas. Assorted colors... Verbena. Lemon scented.... $\quad .15 \quad 1.50 \quad 10.00$ Vincas. Trailing........... Zinnias. Assorted........... $.05 \quad .40 \quad 2.00$ 


\section{Farm Seeds.}

\section{Prices Subject to Market Changes.}

BARLEY.

Vermont. The most productive variety. It ripens early, with strong, stiff straw. Pk., .50 ; bush., $\$ 1.50$.

\section{SPRING RYE.}

Distinct from the winter rye, grain of finer quality and more productive ; can be successfully grown in any latitude, and is now being largely sown in the Middle States in place of oats, being a much more profitable crop, on account of the production of nearly four times the straw, and also as a "catch" crop where winter grain has failed. The straw is equally as valuable as that of the fall or winter rye, standing stiff, 7 to 8 feet high. Produces 30 to 40 bushels of grain per acre. As it does not stool like winter rye, not less than two bushels to the acre should be sown. Pk., .60; bush., $\$ 1.50$.

\section{BUCKWHEAT.}

New Japanese. The kernels are nearly twice the size of any other, of a rich dark brown color, and manufacture a superior flour. It has rapidly displaced all others, and is now more largely planted than any other, being about two weeks earlier. $\mathrm{Pk}$., .40; bush., $\$ 1.50$.

Silver Hull. Qt., 15c.; peck, 40c.; bush., $\$ 1.50$

\section{TRUE DWARF ESSEX RAPE.}

Dwarf Essex Rape, of the True Biennial Variety, is now largely grown in this country on account of its rapid growth, being ready to feed in eight to ten weeks from sowing, and producing twenty-five to thirty tons of green forage to the acre. It grows to a height of three feet and covers the surface so densely as to smother out all weeds. It can be sown all through the season, being perfectly hardy, withstands drought, and will produce a crop in any soil by sowing broadcast at the rate of five to ten pounds to the acre. While unequaled as a pasture for sheep, as a food for all cattle, calves or pigs, it is without a rival, its fattening properties being twice as great as clover, making a much relished and most succulent food from May to December. Lb., .15.

\section{KAFFIR CORN.}

Will make a fine crop of forage if cut in early bloom and the shoots that then follow will mature a full crop of seed and forage. Both grain and fodder are excellent, the whole stalk tender to the full maturity of seed. There is no failure about it, as it possesses the quality that all the tribe possess, of waiting for rain without any loss of capacity to yield. The grain is extremely valuable for feeding to poultry and will make a flour that is like wheat flour. Cultivated the same as our common Indian corn, requiring four to five pounds of seed per acre. Bush., \$1.50.

\section{CANADA FIELD PEAS.}

Very popular as a hay and forage crop, also a very early nutritious dry or green feed. Sow in April at the rate of $1 \frac{1 / 2}{\text { bushels per acre }}$ broadcast with $1 / 2$ bushel oats as a support; cut for hay before the Peas mature. Excellent pigeon feed when dry. Pk., .60; bush., $\$ 2.00$.

\section{MAMMOTH RUSSIAN SUNFLOWER}

The best variety for the farmer. Growing to double the size of the common, and the yield of seed is twice as great. One hundred and twenty-five bushels to the acre have been grown at a less expense than corn. It is highly recommended for poultry ; the best egg-producing food known; the leaves make splendid fodder; much relished by all kinds of stock. The seed is good feed for horses, and yields a fine quality of oil. The strong thick stalks are used for fuel. O.t., .10; pk., .60.

\section{OATS.}

Silver Maine. Very early, handsome, wonderfully fine and productive. Bush., $\$ 1.00$.

\section{Vegetable Plants and Roots.}

Asparagus Roots.

Conover's Colossal...........\$ $.20 \$ .60$

Palmetto $\ldots \ldots \ldots \ldots \ldots \ldots \ldots \ldots, .20 \quad .75$

Cabbage Plants.

Early Jersey Wakefield.........15

Henderson's Summer............ .15

Stone Mason $. . . \ldots \ldots \ldots \ldots \ldots, \quad .15$

Flat Dutch................. .15

Cauliflower Plants.

Early Snowball.............25

Celery Plants.

Golden Self-Blanching........ .20 1.25

White Plume................ . .20 1.25

Giant Pascal.................. .20 $\quad .25$

$\begin{array}{llll}\text { Boston Market................ } & .20 & 1.25\end{array}$

Chives.

15 cents per bunch.......... 1.50
Egg Plants. Doz. 100 New York Improved........\$\$.75 \$5.00

Horse Radish.

Small sets .................. .15 $\quad .50$

Lettuce Plants............... .15 1.00

Mint $\ldots \ldots \ldots \ldots \ldots \ldots \ldots \ldots \ldots \ldots \ldots$

Pepper Plants.

Bell or Bull Nose........... .20 1.50

Sweet Mountain............. $.20 \quad 1.50$

Rhubarb Roots.

10 cents each............... $1.00 \quad 8.00$

Large roots, 50 cents each..... 5.00

Sage $. . \ldots \ldots \ldots \ldots \ldots \ldots \ldots \ldots \ldots . .20$

Tomato Plants.

Acme $\ldots \ldots \ldots \ldots \ldots \ldots \ldots \ldots, \quad .20 \quad 1.50$

$\begin{array}{llll}\text { Dwarf Champion............... } & .20 & 1.50\end{array}$

Perfection .................. .20 1.50 


\section{Grass Seeds $\begin{gathered}\text { for } \\ \text { the }\end{gathered}$}

Prices Subject to Variation. special Prices for Large Quantities.

Timothy (Phleum pratense). The most important agricultural grass known here for haymaking purposes. It is temporary, lasting but a few years, and is part of the usual crop rotation. Sow $1 / 2$ bushel to the acre when used alone. $45 \mathrm{lbs}$. to the bushel. Market price.

Red-Top (Agrostis vulgaris). Suitable for meadow and pasture mixtures, or for lawnmaking. Adapts itself to any soil, but produces best results on moist, rich soils, where it grows 2 to $2 \frac{1}{2}$ feet high. Often sown with Timothy and Clover, and outlasts both. Sow for pasture 3 bushels per acre. Market price.

Red-Top Grass, Extra Recleaned Seed. Market price.

Orchard Grass (Dactylis Glomerata). One of the most valuable of the pasture grasses. Thrives in the open sunlight and in shady places under trees. In rich soil two or three crops may be had in a season. Does not suffer from close feeding; makes a good hay. Sow 3 bushels to the acre. Lb., .20.

Kentucky Blue Grass, Fancy Cleaned (Poa pratensis). Also known as June grass, green grass, etc. This is rated as the finest permanent pasture grass. Especially suited to meadows and rich lands. A perfect lawn grass. Sow 3 to 5 bushels per acre for lawns; 3 bushels to the acre for pasture. Lb., . 20 .

Rhode Island Bent (Agrostis Canina). One of the best grasses for pastures or lawns. Per 1b., .25.

Awnless Brome Grass (Bromus inermis). A valuable grass for light, dry soils. Will stand long droughts and produce heavy crops where other grasses would fail. The U. S. Agricultural Department has been making repeated tests of this variety with the best results. 35 to $40 \mathrm{lbs}$. to the acre. Lb., . 20.

Meadow Foxtail (Alopecurus pratensis). One of the best pasture grasses. $30 \mathrm{lbs}$. to the acre. Lb., .35.
Rough-Stalked Meadow-Grass (Poa trivialis). 30 lbs. to the acre. Lb., .50.

English Rye Grass, or Perennial Rye (Lolium perenne). Considered invaluable for permanent pastures, in all situations not too dry. Sow 60 lbs. to the acre. Lb., .10.

Italian Rye Grass (Lolium Italicum). Valuable for pasture mixtures. $50 \mathrm{lbs}$. to the acre. Lb., .12.

Meadow Fescue (Festuca pratensis). An excellent grass for permanent pasture or hay, the foliage being highly nutritious. Sow 50 1bs. to the acre. Lb., .25.

Tall Meadow Fescue (Festuca elatior). Very early and nutritive; should form a part of all pasture mixtures on wet or clay lands. Per 1b., .45.

Sheep's Fescue (Festuca ovina). Produces a large quantity of short herbage, and should form a part of all mixtures for sheep pastures. $40 \mathrm{lbs}$. to the acre. Lb., .20.

Wood Meadow Grass (Poa nemoralis). Adapted for wooded or shaded meadows or lawns, especially for moist ground. Should be included in mixtures for permanent pastures. Sow 30 1bs. to the acre. Per lb., .60 .

Creeping Bent Grass (Agrostis stolonifera). Excellent for lawns; succeeds well in all positions; makes a low velvety growth. Per 1b., .30.

Tall Meadow Oat Grass (Avena elatior). A valuable grass for soiling or permanint pasture; of early and luxuriant growth. 50 1bs. to the acre. Lb., .28.

Hard Fescue (Festuca duriuscula). Thrives well in dry situations where many other grasses would fail. 30 lbs. to the acre. Lb., .20.

Sweet Vernal Grass (Anthoxanthum odoratum ). True perennial. Use 2 to $5 \mathrm{lbs}$. to acre. Lb., $\$ 1.00$.

Crested Dogstail (Cynosurus cristatus). For pastures and lawns. 25 1bs. to the acre. Lb., .50.

\section{CLOVERS.}

Alfalfa or Lucerne (Medicago Sativa). A
deep rich soil is best adapted to the cultivation of this plant. In such, several crops are produced in a season. Market price.

Red Clover Medium (Trifolium pratense). The common red clover in general cultivation. Market price.

White Clover (Trifolium Repens). Valuable for permanent pastures and is also used with lawn grass. Market price.

Alsike or Swedish (Trifolium Hybridum). Valuable for hay or pasturage. Thrives well in cold, wet and stiff soils. Market price.

Crimson or Italian Clover (Trifolium Incarna= tum). An annual variety, with long blossoms of a deep red color Excellent for soiling. Market price.

MILLET,

Golden Millet. Of great value as an annual hay and fodder crop. Market price.

Hungarian Grass (Panicum Germanicum). An annual forage plant of great value. One of the best plants for green fodder, ensilaging or hay. It will grow in any ordinary soil. Withstands drought well. : Market price

Japanese Millet. Succeeds best in a moderately moist soil, and may be sown from the middle of May until the first of July. Is quite distinct from other varieties; enorwous cropper, grows six to eight feet high, excellent either green or cured as hay. Per $1 \mathrm{b.,} .10$. 


\section{SPECIAL GRASS SEED MIXTURES. \\ Mixture for Shady Places.}

This is a mixture of extra fine grasśes adapted for growing in the shade. We recommend the use of this mixture wherever other grasses have failed to make a close sward. Qt., .30; 4 qts., $\$ 1.00 ;$ pk., \$1.50.

\section{PARK LAWN GRASS.}

\section{Mixture for Lawns, Tennis Courts, Croquet Grounds.}

There is nothing more beautiful and pleasing to the eye than a well-kept lawn, with its close, velvety turf. To insure this the principal object is to use good seed. For this purpose we recommend our "Park" Lawn Grass Mixture, which is composed of dwarf and close growing grasses, and best adapted to produce a fine, velvety lawn. The seed may be sown either in spring or fall. Four bushels of seed are required per acre. Per qt., .20; 4 qts., .60; pk., $\$ 1.00 ;$ bush., $\$ 3.50$.

\section{TERRACE MIXTURE.}

This is a mixture of Foreign and Domestic Grasses, which are especially adapted to make a permanent sod, thereby avoiding all danger of having the Terrace broken by heavy rains. We strongly recommend this mixture to all those desirous of having perfect Terraces all the year. Qt., .30; 4 qts., $\$ 1.00 ;$ pk., $\$ 1.50$.

\section{GRASSES FOR PERMANENT PASTURES AND MEADOWS.}

Containing only the most suitable Grasses, the proportionate quantity of each being regulated by soil, situation, and purpose for which desired. The object to be attained is a constant, successful growth of rich pasturage from spring to fall. It is a well-established fact that soils sown with a variety of different grasses which are adapted to the soil, and which attain perfection at alternate months from April to September, produce very much larger and more satisfactory crops, both for hay and pasturage, than when only one or two kinds of grasses or clovers are sown. The results given by our mixtures have been most satisfactory. We unhesitatingly recommend them for use on the largest scale. Fall seeding is preferable, but spring sowing will be successful if done early, when the land is cool and moist.

Mixtures for Permanent Pastures for One Acre.

FOR GOOD SOILS, COOL AND MOIST.

8 1bs. Timothy.

5 “ Red Top.

4 " Orchard Grass.

5 “ Perennial Rye Grass.

3 " Sheep's Fescue.

$11 / \%$ " Hard Fescue.

2 " Meadow Fescue.

2 "Tall Oat Grass.

2 "Meadow Foxtail.

7 “ Kentucky Blue Grass.

$1 / 8$ “ Perennial Sweet Vernal. 40 lbs. per acre, $\$ 6.00$.

FOR DRY SOILS.

10 1bs. Timothy.

5 " Creeping Bent.

5 " Orchard.

$3 \frac{1}{2}$ "Tall Oat Grass.

2 " Hard Fescue.

4 " Sheep's Fescue.

1 "Sheep's Fescue, fine leaved.

1 " Meadow Foxtail.

$1 / 8$ " Perennial Sweet Vernal.

8 " Perennial Rye Grass. 40 lbs. per acre, $\$ 650$.

FOR IVET SOILS.

1bs. Timothy.

" Red Top.

" Kentucky Blue Grass.

"Orchard Grass.

" Perennial Rye Grass.

“ Meadow Fescue.

"Tall Fescue.

" Meadow Foxtail.

" Rough Stalked Meadow Grass.

“ Various Leaved Fescue. 40 lbs. per acre, $\$ 6.50$.

\section{.}

\section{Mixtures for Permanent Meadows for} One Acre.

FOR GOOD SOILS, COOL AND MOIST.

17 1bs. Timothy.

5 " Red Top.

3 " Orchard Grass.

5 " " Perennial Rye Grass.

1 “ Meadow Foxtail.

2 "Tall Oat Grass.

2 "Hard Fescue.

2 " Sheep's Fescue.

$11 / 2$ " Italian Rye Grass.

1 " Various Leaved Fescue.

$1 / 2$ "Perennial Sweet Vernal. 40 lbs. per acre, $\$ 5.75$.

FOR HIGH, DRY SOILS.

15

5

7

4

3

3

1

1

1 


\section{Flower Seeds.}

All Flower Seeds are Sent Free by Mail on Receipt of Price. The Smallest Quantity of Flower Seeds Sold by Weight is Ten Cents Value.

A common mistake in sowing flower as well as other seeds is covering too deep. As a general rule, cover only to the depth of the thickness of the seeds, or with medium-sized seeds, like Bal. sams, Zinnias, etc., half an inch or so is none too much. Such fine seeds as Portulacas need only to be pressed into the soil with a piece of board or the palm of the hand. Always press the earth down firmly after sowing all flower seeds, else there is danger of their drying up before the roots can get firm hold of the soil. Seeds of the hardier Annuals may be sown where they are to grow; but as a rule it is preferable to transplant, as the plants are generally stronger and stand the drought better. During very dry weather, and when the seedlings are first set out, they should be watered frequently. Provide some support for all such Annuals as require it, else the plants become weak and straggling, and do not make the show they otherwise would.

Abronia. Beautiful trailing annuals, with clusters of Verbena-like flowers, $1 \mathrm{ft}$.

Umbellata. Rose with white eye........05

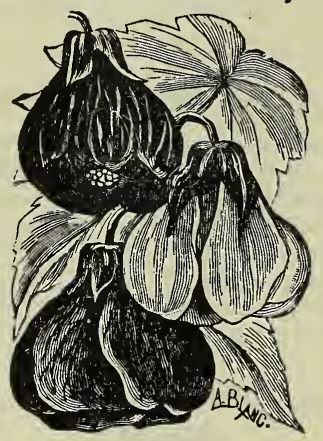

Abutilon

Abutilon. Decorative shrubs, with beautiful bell-shaped flowers; choice mixed .10

Acacia. Half-hardy shrubs, with graceful foliage and beautiful racemes of flowers, mostly shades of yellow; attaining a height of 8 to $12 \mathrm{ft} . . . \ldots \ldots \ldots \ldots \ldots$

Acroclinium. A beautiful everlasting flower valuable for winter bouquets ; annual.

Album. Single, pure white, $1 \mathrm{ft} . \ldots \ldots \ldots .05$

Roseum. Bright rose, $1 \mathrm{ft} \ldots \ldots \ldots \ldots \ldots .05$

Aconitum, Monk's Hood. Hardy perennial plants, with showy spikes of hoodshaped blossoms, $4 \mathrm{ft}$.

Napellus. Blue and white........... 05

Adonis. Handsome and showy flowers, remaining a long time in flower; annual.

Aestivalis (Flos Adonis). Scarlet, $1 \mathrm{ft} . . \quad 05$

Adlumia, Cirrhosa (Mountain Fringe). A charming, hardy, biennial climber; blooming the first season, $15 \mathrm{ft} . . . \ldots$.

Ageratum. Fine plants for massing outside, also for winter blooming in the house.

Imperial. Dwarf, blue, $3 / 4 \mathrm{ft} \ldots \ldots \ldots \ldots . .05$

Imperial. Dwarf, white, $3 / 4 \mathrm{ft} \ldots \ldots \ldots \ldots .05$

Mexicanum. Blue, $1 \frac{1}{2} \mathrm{ft} \ldots \ldots \ldots \ldots \ldots .05$

Mexicanum. Album, white, $11 / 2 \mathrm{ft} \ldots \ldots .05$

Agrostemma. Free flowering and attractive border plants.

Coeli Rosea (Rose of Heaven). Annual,

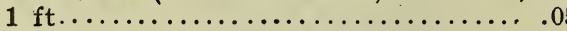

Alonsoa. Charming annual, easily grown, and very desirable, $1 \frac{1}{2} \mathrm{ft}$.

Grandiflora. Scarlet; very fine....... .05

Aloysia Citriodora (Lemon scented Verbena). Tender perennial............10
Alyssum. Free flowering plants, serviceable for beds, borders, or rock work.

Maritimum (Sweet Alyssum). Fragrant white ; annual, $1 \mathrm{ft}$., oz., .25..........

Benthami Compactum. Dwarf ; compact growth; annual, $1 / 2 \mathrm{ft} . \ldots \ldots \ldots . .05$

Saxatile Compactum. Bright yellow flowers; perennial, $3 / 4 \mathrm{ft} . . . \ldots \ldots \ldots .$.

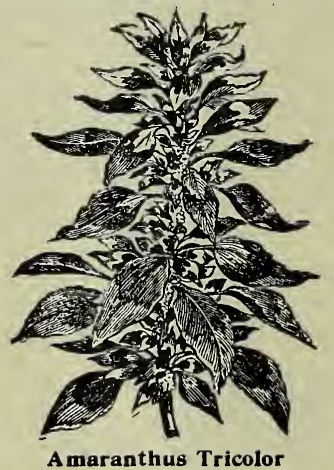

Amaranthus. Highly ornamental foliage plants of easiest culture; annual.

Bicolor Ruber. Carmine scarlet, $2 \mathrm{ft}$... .05

Caudatus (Love lies bleeding). Long drooping, scarlet flowers, $3 \mathrm{ft}$.... . . .05

Cruentus. Tall spikes of red flowers, $3 \mathrm{ft}$. .05

Salicifolius (Fountain Plant). Long undulated foliage, beautiful, variegated, $3 \mathrm{ft}$. .05

Tricolor Splendens (Joseph's Coat). Glowing, scarlet crimson, effectively marked with yellow and bronze green,

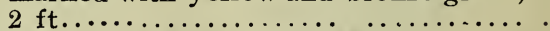

Ammobium, Alatum Grandiflorum. Pure white, everlasting flowers, valuable for winter bouquets ; annual, $2 \mathrm{ft} . . . . . .$. Ampelopsis, Veitchi (Japanese or Boston Ivy ). A beautiful clinging vine, easily raised from seed, perfectly hardy;

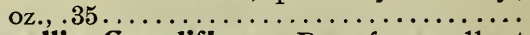

Anagallis, Grandiflora. Dwarf ; excellent for borders, baskets, and rock work; mixed sorts; annual. ................

Anemone, Coronaria. Very beautiful
spring flowers, and easily grown; mixed colors ; perennial, $1 / 2 \mathrm{ft} . . . . .$. .

Antirrhinum (Snapdragon). Beautifu1 summer and autumn flowering plants; succeeds well in any dry, loamy soil; annual.

Grandiflora Mixed. Choice large flowering sorts........................ . . . colors, $1 / 2 \mathrm{ft} . \ldots \ldots \ldots \ldots \ldots \ldots \ldots \ldots \ldots$ 


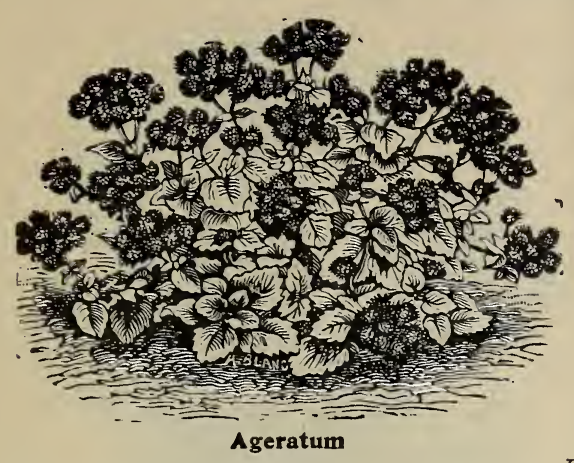

Anchusa, Capensis. Azure blue flowers, splendid for bouquets; annual........ .05

Aquilegia (Columbine). An extremely showy and ornamental plant, perennial.

Double mixed, finest sorts, $2 \mathrm{ft} \ldots \ldots \ldots$.

Aristolochia, Elegans. Handsome greenhouse climber, with curiously.shaped flowers; reddish-purple veined with white, the eye being golden yellow....

Asparagus Sprengeri. Excellent for pots or hanging baskets $\ldots \ldots \ldots \ldots \ldots \ldots \ldots, .25$

Plumosus Nanus. A greenhouse perennial climber......................25

Asperula, Azurea Setosa. Blue, beautiful and fragrant, grows well in shady places, annual, $1 \mathrm{ft} . \ldots \ldots \ldots \ldots \ldots \ldots$.

Odorata (Woodruff). Flowers white; sweet-scented. Excellent for rock work, perennial, $1 \mathrm{ft} . \ldots \ldots \ldots \ldots \ldots \ldots \ldots . . . .$.

Asters. The seeds should be sown early in the spring in a hotbed, and transplanted outdoors when the weather is warm, about one foot apart. For best results Asters should have a good rich soil and plenty of moisture, although they will do well in ordinary garden soil; annuals.

Ostrich Feather. More feathery appearance than the Coniet Aster, resembling some of the large Japanese Chrysanthemums with long, curved, fringe-like petals.

White, rose, crimson, light blue, dark blue, mixed; each....................10

Giant Comet. The petals are twisted and curled, resembling the Japanese Chrysanthemum; mixed colors........ .10

Giant Comet. White.............. .10

Triumph. One of the most beautiful dwarf asters ever introduced. Flowers deep scarlet and very large ............. 10

Trauffut's Pæony Flowered Perfection. This is the most perfect type of pæony flowered aster in cultivation; the flowers are perfect in quality, form, size and color; finest mixed colors..........10

Trauffut's Pæony Flowered Perfection. White, pink, purple, scarlet; each..... .10

Victoria. One of the most beautiful asters in cultivation; flowers large, beautifully imbricated, and pyramidal in form; finest mixed ..............

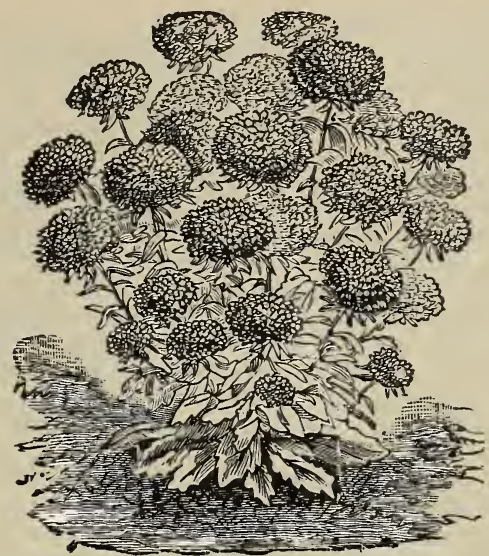

Victoria Aster.

Victoria. White, pink, purple, scarlet; each ......................... .10

Washington. The largest aster grown, bearing flowers 4 to 5 inches in diameter and very double; mixed colors......... 10

Queen of the Market. The earliest flowering aster; finest mixed............ .10

Semple's Late Flowering Branching. The flowers are large, resembling the chrysanthemum, and borne on long stems; desirable for cutting; strong growing plants, 2 to $3 \mathrm{ft}$. high.

White, Lavender, Shell Pink, Crimson, Dark Blue, Mixed; each .............. .10

Daybreak. Sea shell pink ............... .10

Perennial. Finest Mixed................ 10

Bachelor's Button (See Centaurea Cyanus).

Balloon Vine. A rapid and graceful climber; annual................... .05

Balsam. One of the finest and most popular summer blooming annuals. They succeed best in a rich soil, and should receive frequent watering of liquid manure.

Camelia-Flowered. Finest Mixed; large double flowers.....................

Camelia-Flowered, Pure White........ .05

Bartonia, Aurea. Very showy annual, with golden yellow flowers............

Begonia, Tuberous. Beautiful summer and autumn flowering plants; easily raised from seed.

International Prize. An unsurpassed strain, saved from selected flowers; finest mixed $. . . \ldots \ldots \ldots \ldots \ldots \ldots \ldots . .30$

Double. Splendid mixed............. .50

Vernon. A grand variety; flowers waxy blood scarlet; foliage very beautiful... .20

Rex. Large, handsome leaves dark green, variegated with red bronze, red and silver white; greenhouse perennial; $1 \mathrm{ft} . .25$

Bellis Perennis. Double daisy. A favorite plant for edging or pot culture. Perennial.

Maxima. The flowers are densely double and as large as a silver dollar; of red and rose tints..................... 
Bellis Perennis - (Continued).

Longfellow. Double, dark rose flowers.

Snowball. Pure white, double daisy.... .10

Double Finest Mixed. Oz., $\$ 4.00 \ldots \ldots \ldots .10$

Browallia. One of the finest flowers for pots, basket or edging.

Elata. Fine mixed; annual...........

Brachycome, Iberidifolia (Swan River Daisy ). Elegant, half hardy annual, with handsome blue flowers, 9 in......

Alba. White flowers...............

Calendula. Very showy, free-flowering annuals; excellent for beds, borders, etc.

Meteor. Double, light orange striped;

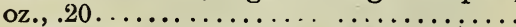

Le Proust. Double, nankeen color; oz., . $20 \ldots \ldots \ldots \ldots \ldots \ldots \ldots \ldots \ldots$.

Prince of Orange. Darker orange than

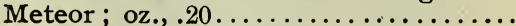

Fine Mixed. Oz., $20 \ldots \ldots \ldots$........ 05

Cacalia (Tassel Flower). Pretty free, hardy annuals; producing trusses of showy, tassel-like flowers, $1 \mathrm{ft}$.

Coccinea. Orange scarlet

Calceolaria. Remarkable for their la.................. beautifully spotted blossoms.

James' Giant Strain. Choicest mixed.. .50

Large-Flowered, Spotted. Finest mixed .50

Calliopsis. This genus is amongst the most showy, free flowering, hardy annuals.

Drummondi. Yellow.................. 05

Mixed. Finest varieties ; oz., .30.

Grandiflora. Large, golden yellow, $3 \mathrm{ft}$;

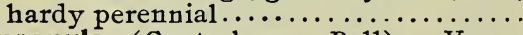

Campanula (Canterbury Bel1). V e ry showy; excellent for borders, etc.

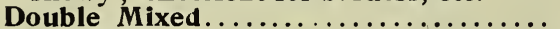

Calcyanthema. Mixed................05

Candytuft. One of the most popular and useful border plants; very effective in beds, groups, etc.; excellent for cut flowers ; annual.

Crimson Dunnett's. Oz., .25.........05

Rocket. White, free flowering; oz., .25 .05

Purple. Excellent for bedding; oz., .25 .05

Empress. New; pure white; long spikes ; oz., .40................

Mixed. Annual varieties ; oz., $20 \ldots \ldots \ldots .05$

Carter's Carmine. Oz., .40........... .05

Canna, Dark Leaved Varieties. Mixed;

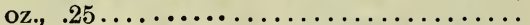

Crozy's Large Flowering Dwarf French. Mixed colors; oz., .50..............

Queen Charlotte. Scarlet and yellow... . 10

Madame Crozy. Large spikes of deep vermilion; golden bordered flowers...

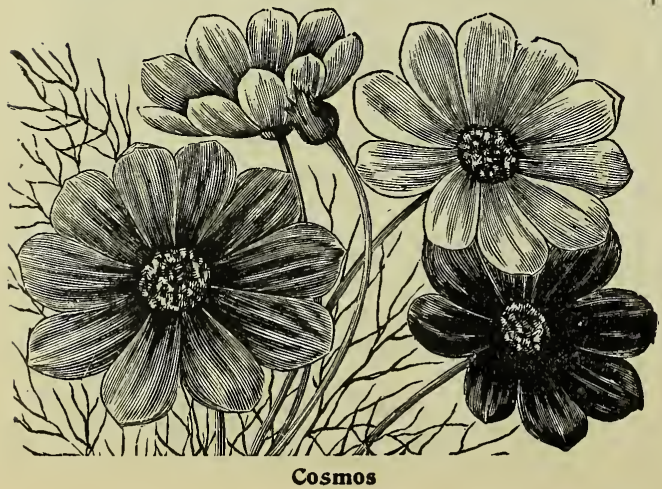

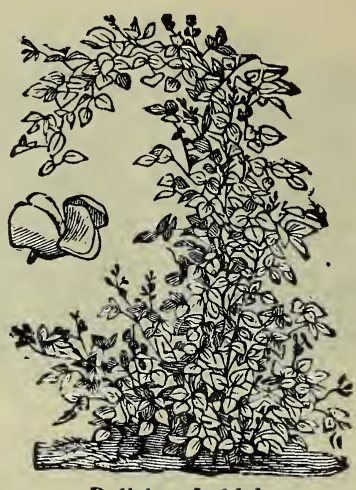

Dolichos Lablab

Carnation, Double Finest Mixed.........10

Marguerite. A beautiful strain of carnations, blooming in four months from the time of sowing the seed; mixed... .10

Marguerite, White. Pure white, double .10

Marguerite, Yellow..................10

Marguerite, Giant.................15

Castor Oil Beans. (See Ricinus.)

Celosia (Cockscomb). Very showy, freeflowering plants; producing spikes of feathery flowers. Sow early, and transplant out in June ; annual.

Cristata Nana. Choicest mixture of the newest dwarf varieties.............. 05

Ostrich Feather. Crimson, large plumes .10

Glasgow Prize. Dwarf variety, with dark foliage and crimson combs .......... 10

Thompsoni. Two feet tall, with beautiful feathery plumes of brilliant crim. son ..........................10

Centaurea, Candidissima. Silvery-white, deeply cut foliage; $1 / 8$ oz., .30........ .10

Gymnocarpa. Silver-gray foliage, drooping habit; oz., $.75 \ldots \ldots \ldots \ldots \ldots \ldots \ldots . .10$

Cyanus Mixed (Bachelor's Button ). Favorite annuals ; fine for cutting; oz., .25

Cyanus Blue. Oz., .25............. 05

Cyanus=FIore Pleno. New, double Bachelor's Button; oz., .40.............. 05

Marguerite. Pure white, very large flowers; fragrant................. .10

Victoria. Dwarf, azure blue, $1 \mathrm{ft} . . . . . . .10$

Suaveolens. Yellow flowers; sweet scented; oz., .75..................05

Moschata (Sweet Sultan). Finest mixed, sweet scented; fine for cutting; oz., .30

Centrosema, Grandiflora (Butterfly Pea). A hardy, perennial vine of exquisite beauty, which blooms early in June from seed sown in April; height $8 \mathrm{ft}$........

Chrysanthemum, Single Annual Va-

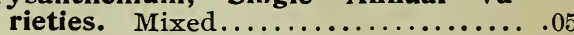

Double Annual Varieties. Mixed..... .05

Segetum Grandiflorum. Sulphur yellow, flowers $2 \frac{1}{8}$ ins. across................

Frutescens (Marguerite). White with

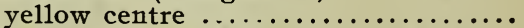

Japanese Finest $M$ Mixed. Prize strain..

Cineraria. Magnificent flowering plants for greenhouses, etc., in winter and spring.

Double Large Flowering. Mixed...... .50

Maritima (Dusty Miller). Silvery leaved, ornamental plants, used for bedding purposes; oz., .50. .............. 


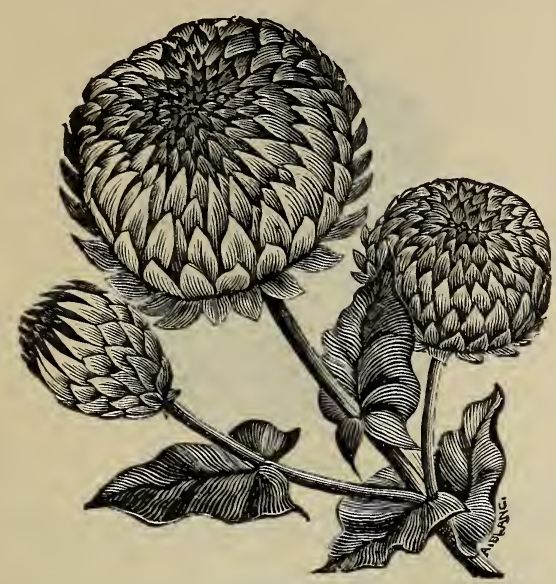

Elichrysum

Clarkia. Mixed; free flowering; hardy

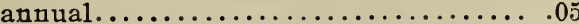

Clematis, Hybrids. Splendid, large and free flowering hardy climbers. $20 \mathrm{ft} .$. .

Cobaea Scandens. A beautiful, half-hardy climbing plant of rapid growth, with

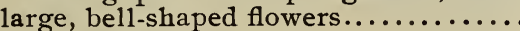

Alba, White...

Coleus, New Hybrids. Mixed. A wellknown ornamental foliage plant....

Colinsia. Finest Mixed. Charming hardy annuals. Flowers white, lilac and

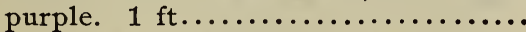

Convolvulus, Imperial Japanese Morning Glory. Finest mixed; oz., .25......

Convolvulus, Major (Morning Glory). Finest mixed; annual; $15 \mathrm{ft}$.; oz., .10..

Cosmos, Hybridus. The flowers are from 3 to 4 in. in diameter, resembling single dahlias; excellent for cutting; easily raised from seed and bloom the first season.

Giant Early Flowering Mixed..........10

White...........................10

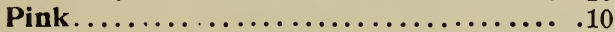

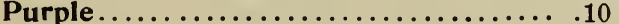

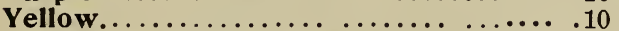

Cyclamen, Percicum Giganteum. Choice strain; mixed..................

Cypress=Vine (See Ipomœa).

Cyperus Alternifolius (The Umbrella Plant). Handsome foliage plant; excellent for table decoration; easily grown from seed ..................

Dahlia, Cactus Large Flowering. Seed saved from choice varieties; mixed... .10

Single Mixed. Saved from a superb collertion..........................10

Double Finest Mixed. Very beautiful.. .10

Daisy, Shasta. Flowers of the snowiest white, with yellow centres; large and graceful, and produced in countless numbers on long, strong stems; perennial, and blooms the first season from seed ................................

Delphinium (Larkspur). Very showy, bearing large spikes of flowers.
Double Dwarf Rocket. Fine mixed; annual; oz., .25................. 05 Double Tall Rocket. Mixed; oz., .25.. .05

Dwarf Candelabrum. Finest mixed... .05

Datura Cornucopia. Mixed; bushy plants ; trumpet-shaped flowers; fragrant, $3 \mathrm{ft}$. .05

Dianthus. A beautiful class of plants.

Chinensis, Fl. Pl. (China or Indian Pink). Mixed; oz., 30

Heddewigi, HI. MI. (Japan Pink). Large flowering; double choice mixed ; oz., .60

Barbatus (Sweet William). Single mixed; biennial; oz., .25 .................

Imperialis Flore Pleno (Double Imperial Pink). Variegated flowers of many colors ...........................................

Barbatus. Double mixed; large flowering; oz., $.50 \ldots \ldots$. . . . ......

Digitalis. Very showy plant for shrubberies and half shady places; perennial.

Purpurea. Fine mixed...............

Ivery's Spotted. Large flowers; white

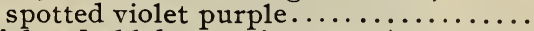

Dolichos Lablab (Hyacinth Bean). Mixed ; a beautiful, quick growing climber, with blue and white flowers in clusters;

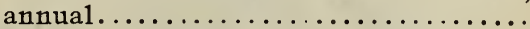

Dracæna. Decorative foliage plants.

Indivisa. Narrow dark green foliage... .10

Latifolia. Broad Leaved ..............10

Echinocystis, Lobata (Wild Cucumber). Rapid growing, hardy, annual climber,

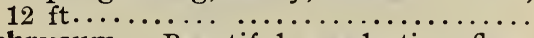

Elichrysum. Beautiful everlasting flowers; for winter bouquets; annuals.

Double Mixed Varieties............. . 05

Dwarf Double. Finest mixed............. .05

Eschcsholtzia (California Poppy). Free flowering, handsome annuals, with bright, showy flowers, blooming all through the season till frost.

Mandarin. Rich orange inside; outside brilliant scarlet................... . 05

Finest Mixed. A11 colors............05

Euphorbia.

Heterophylla (Mexican Fire Plant). Showy annual, with large glossy leaves, which in midsummer become tipped with orange-scarlet; $4 \mathrm{ft} . . . \ldots . . . \ldots$.

Variegata. White and green bracts; useful for bouquets $; 1 \frac{1}{2} \mathrm{ft} . \ldots . \ldots . . .05$

Ferns, Finest Mixed. Best greenhouse and stove varieties ..................25

Hardy Varieties Mixed. Best sorts for outdoor growing ..................25

Feverfew (See Matricaria).

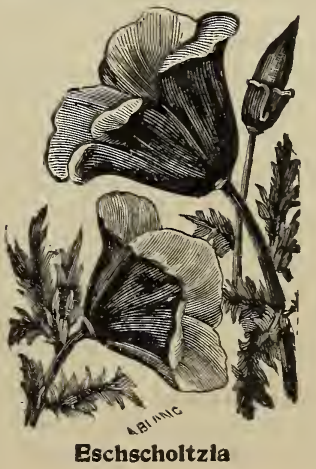

\section{5}

\section{5}


Forget-Me-Not. ( See Myosotis).

Gaillardia. Splendid bedding plants; remarkable for the profusion of brilliant flowers during the summer and autumn.

Lorenziana. Large flowering, double

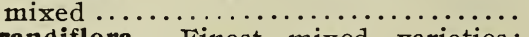

Grandiflora. Finest mixed varieties; perennial ..................... 05

Geranium. Large flowering; choicest varieties ......................15

Godetia. Showy, free-flowering annuals; suitable for beds and borders.

Fine Mixed. From the best varieties... .05

Golden Feather. (See Pyrethrum).

Gomphrena. $\mathrm{H}$ a n d so w e, everlasting flower; mixed, all colors.............

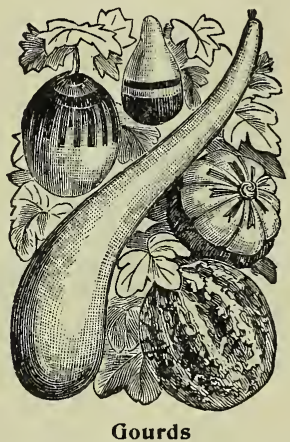

Gourds (Ornamenta1). Quick-growing vines; producing useful and ornamental fruit; annual.

Mixed Sorts. In great variety....... .05

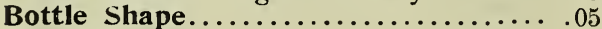

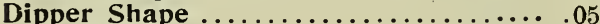

Dish Cloth ......................... . .

Hercules Club.................... 05

Grevillea Robusta. Graceful evergreen, foliage plant; tender perennial...... .05

Gypsophila. A pretty free-flowering plant, adapted for rock work, edging, etc.

Muralis. Dwarf rose; Hardy annual; $3 / 4 \mathrm{ft} . \ldots \ldots \ldots \ldots \ldots \ldots \ldots$

Paniculata. White; fine for cutting; perennial; $2 \mathrm{ft} \quad . . \ldots \ldots \ldots \ldots \ldots \ldots$.

Helianthus (Sunflower). A well-known genus of hardy annuals, with large and showy flowers.

Californicus, Fl. Pl. Orange ; extra large and double ; $5 \mathrm{ft} . ;$ oz., .30............

Cucumerifolius. Orange yellow flowers; $3 \mathrm{ft}$., single; oz., .25 ............

Cucumerifolius Stella (Large Flowering Miniature Sunflower). Flowers are from $2 \frac{1}{2}$ to 3 in. across, borne on long stems, golden yellow flowers; $4 \mathrm{ft}$. ; Globosus Fistulosus, Fi. Pi. Globeshaped; yellow ; $6 \mathrm{ft}$; oz., .25....... .05

Nanus. Dwarf, double flowers; $4 \mathrm{ft} . .$. . .05

Nanus Variegatis. Dwarf, handsome variegated foliage ; $4 \mathrm{ft} \ldots \ldots \ldots \ldots \ldots$.

Heliotrope. Finest mixed favorite halfhardy plants for bedding and pot cul-

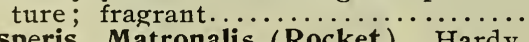

Hesperis, Matronalis (Rocket). Hardy, perennials, with lilac-purple or white flowers ; height, $3 \mathrm{ft}$; mixed colors....

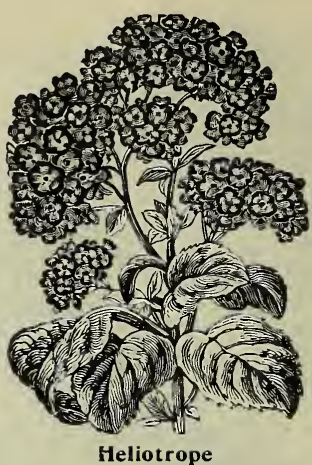

Humulus Japonicus (Japanese Hop). An annual climber, growing with great rapidity $; 20 \mathrm{ft} . \ldots \ldots \ldots \ldots \ldots \ldots \ldots . .05$

Variegatus. New variety, with handsome variegated foliage.............

Hollyhock. This is one of the finest ornamental plants, with spikes of flowers of almost every color; they do best in deep, dry soil, enriched with plenty of manure.

Chater's Prize. Choice double mixed.. .15

Crimson ..................... 10

Yellow ........................

Pure White................... 10

Magenta .......................10

Pink......................... .10

Double Finest Mixed. Oz., $\$ 1.00 \ldots \ldots . .10$

Ice Plant. Dwarf growing plants; useful for rock work, baskets, etc. ; excellent for garnishing; annual ..............

Impatiens Sultani. Free blooming plants, with very showy flowers; bright rose; tender perennial ; $2 \mathrm{ft} . . . \ldots \ldots \ldots \ldots .$.

Ipomoea, Quamoclit (Cypress Vine). A well-known climbing vine, with delicate ferm-like foliage and star-shaped flowers; annual; $15 \mathrm{ft} . . . \ldots \ldots . . .$.

Grandiflora (Hybrid Moon Flower). Large, pure white, fragrant flower; opening in the evening...............

Larkspur. See Delphinium.

Lantana Hybrida. Handsome, free-flowering plants, with beautiful trusses of various hues; finest mixed........... .0

Lathyrus Latifolius (Perennial Pea). Freeflowering; hardy; perennial climber; mixed colors..................... 


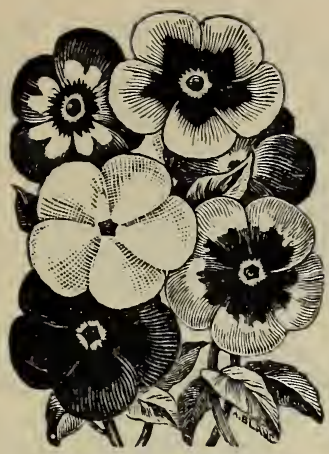

Phlox Drummondii

Linum (Flowering Flax). Handsome freeflowering plants, $1 \mathrm{ft}$.

Grandiflorum Rubrum. Dark scarlet annual...........................

Perennial. Finest mixed .............05

Lobelia. Dwarf growing plants of easy culture, and admirably adapted for beds, edging, etc.

Gracilis. B1ue, best for hanging baskets :10

Crystal Palace Compacta. Dark blue; compact growth...... .......... .10

Emperor William. Light blue flowers; compact variety.................. .05

Speciosa. Dark blue, trailing........... .05

Lunaria (Honesty). Early blooming, freeflowering plants of various colors, grown mostly for the large silvery seed pods. Hardy biennial, $2 \mathrm{ft}$.

Finest Mixed...................... .05

Lychnis. Useful plants of easy culture; the bright and attractive flowers are very effective. Hardy perennial, $2 \mathrm{ft}$.

Finest Mixed Hybrids. Choice colors . . .05

Chalcedonica. Scarlet................05

Marigold. (See Tagetes).

Matricaria (Feverfew). Handsome freeflowering plants, fine for bedding or pot culture; annual.

Capensis. Dwarf; double white; very fine............................ .05

Mimulus, Moschatus (Musk Plant). Sweetscented yellow flower; fine for hanging baskets..........................

Tigrinus Grandiflorus. Very large flowering; tigered and spotted varieties..... .10

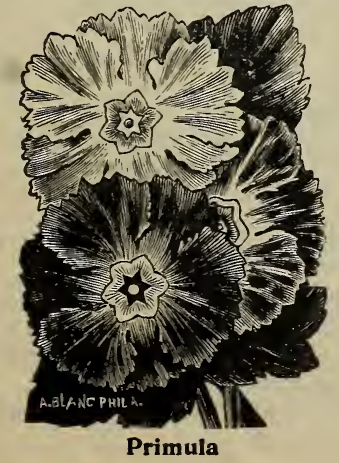

Marvel of Peru (Four O'clock.) Summer blooming plant. Oz., .10. Mixed colors. .05 Variegated foliage, $2 \mathrm{ft}$. Oz. $15 \ldots \ldots \ldots .05$

Morning Glory. (See Convolvulus).

Musa Ensete (Abyssinian Banana). Magnificent foliage plant for sub-tropical massing ........................

Mimosa Pudica (Sensitive Plant). The leares instantly close when touched or shaken. Tender annual..............

Maurandia. Excellent climbing plant for house or garden; splendid for hanging baskets, window boxes, etc.; mixed

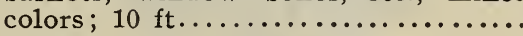

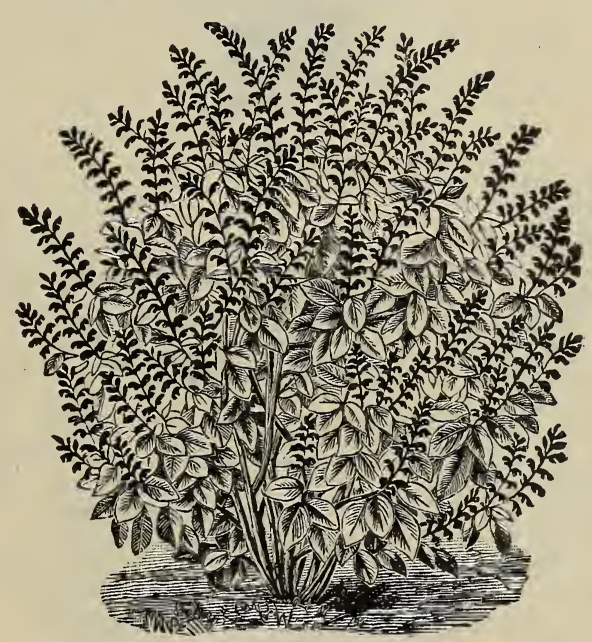

Salvia Splendens

Mignonette, Reseda.

Grandiflora. Large, flowering, fragrant; oz., .15..........................

Golden Queen. Golden yellow flowers, dwarf and compact; oz., .30 ......... .05

Bismarck. New; an improvement on the Machet..........................10

Giant Pyramidal. Large red flowers;

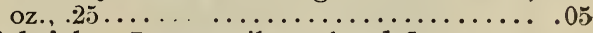

Gabriele. Large spikes of red flowers... . 10 Miles Spiral. Splendid long spikes; oz., .25............................. .05

Parsons'. White. White and buff; very fragrant; oz., .40 ................. .05

Machet. The best for pot culture; long spikes; oz.. .75...................... .10

Allen's Defiance. Very large spikes; 12 to 15 inches long; fragrant; the best variety for forcing under glass; oz., .75 .10

Momordica Balsamina (Balsam Apple). Beautifu1 climbing plant, with handsome apple-shaped fruits; $10 \mathrm{ft} \ldots \ldots \ldots .05$

Charantia (Balsam Pear); $10 \mathrm{ft} . . . \ldots \ldots . .05$

Nasturtium. (See Tropæolum).

Nicotiana, Affinis. Sweet scented; pure white star-shaped flowers, 3 in. across; annual ........................

Colossea. Reddish foliage; very handsome, $10 \mathrm{ft} . \ldots \ldots \ldots \ldots \ldots \ldots \ldots \ldots \ldots . .10$

Nigella, Damascena. Double mixed. Pretty annuals, known as "Love in a Mist".. .10 


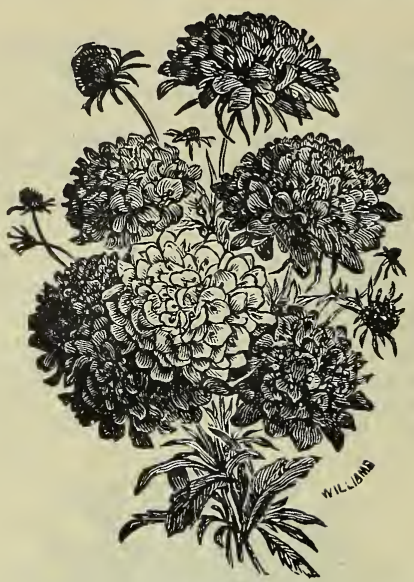

Scabiosa

Myosotis. (Forget-Me-Not).

Pkt.

Blue........................... 10

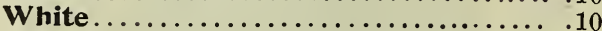

Rose............................. .

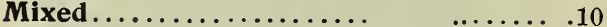

Victoria. Dwarf variety, with large flowers; finest for pot culture.. ......... . 10

Palustris. (True Forget-Me-Not). Dark

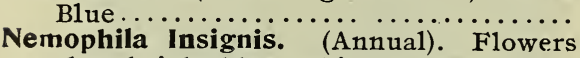
clear bright blue, white centre........05

Finest Mixed ....................... 05

Oenothera, Biennis. (Evening Primrose). Half hardy annual; free-flowering plants for shrubbery, etc................

oxalis. Very attractive plants, with richly colored flowers, splendid for baskets, vases, etc. Half hardy perennial.

Alba. White-flowered.

Rosea. Fine rose color $\cdots \cdots \ldots \ldots \ldots \ldots .10$

Tropaeoloides. Dwarf purplish-brown foliage and yellow flowers...........

Pansies, Fine Mixture ................. . 05

Finest German Mixed. From a splendid strain of large flowering and finely

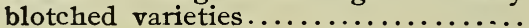

Large Flowering Prize Special mixture prepared by ourselves, which embraces the most striking and beautiful colors, oz., \$5.00 ........................

Bugnot's Superb Blotched. Very beautiful; extra large flowering variety.... .20

Odier. A distinctly blotched variety..... 20

Trimardeau, or Giant Pansies. Beautiful class of vigorous growth, and flowers of enormous size; oz., \$2.50.......

Cassier's. A splendid strain, beautifully marked, large flowers ...............

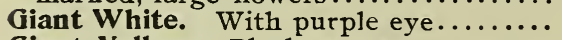

Giant Yellow. Black centre...........

Non Plus Ultra. Flowers of perfect form

Masterpiece. This superb Pansy is distinct from all others, the border of every petal being conspicuously undulated and curled. The flowers are extremely large and have combinations of colors unknown to other Pansies......

Paonia, Double Mixed. These are among the noblest and most beautiful hardy flowers, and indispensable for the garden ................................ .10
Penstemon. If sown in heat in February or March they will flower freely, the first year producing large spikes of handsome flowers. Perennial, $3 \mathrm{ft}$.

Finest Mixed.....................10

Petunia. A profuse-flowering favorite annual.

Hybrida. Single, finest mixed ; oz.,.75..

Alba Pure

Striped and Blotched. Very attractive; oz., $\$ 1.00 \ldots \ldots \ldots \ldots \ldots \ldots \ldots \ldots \ldots$.

Fimbriata Flore Pleno Very large fringed; finest double mixed... ......

Grandiflora, Single. Large flowering; choice mixed......................

Fimbriata. Finest mixed; beautifuli fringed flowers, in great variety of col-

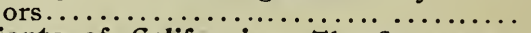

Giants of California. The flowers are very large and of great substance......

Howard's New Star.

Plants have frequently been seen to expand 100 blooms at one time, most of which measured over 2 inch. in diameter

Phlox Drummondii. Hardy annual.

Finest Mixed. A much improved strain with very large flowers, in great variety of colors; oz., $.75 \ldots \ldots \ldots \ldots \ldots \ldots \ldots \ldots . .05$

Alba. Very large, pure white........ 05

Atropurpurea. Purple............... 05

Coccinea. Brilliant scarlet............ 05

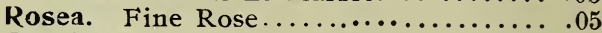

Cuspidata, Finest Mixed. Beautiful star-shaped flowers in showy colors.... .05

Decussata. (Perennial); large bushes, about 3 feet high. Mixed............ .05

Nana Compacta, Extra Fine Mixed. A dwarf-growing, and really handsome

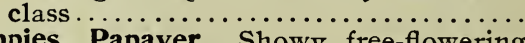

Poppies, Papaver. Showy free-flowering plants for beds or borders; aunual.

Glaucum, (Tulip Poppy). Vivid scarlet flowers ; single.... $\quad \ldots \ldots \ldots \ldots \ldots$

Danebrog. (Danish Flag). Brilliant scarlet, with white blotch on each petal.... .05

Umbrosum. Crimson, with black blotch on each petal.................... . 05

Double Carnation. Mized; handsome double fringed flower; oz., .20......

Double Paony. Mixed; large pæonyshaped flowers; oz., .20............. .05

Oriental. (Oriental Poppy). Deep scarlet with black blotches at the base of each petal. Perennial.............. 0 ô

Shirley. Single, mixed colors; oz., .40.. .05

Double Shirley. Semi-double flowers, beautiful ; oz., $40 \ldots \ldots \ldots \ldots \ldots \ldots \ldots$. . 0

Nudicaule. (Iceland Poppy). Single, finest mixed.................... . 05

Polemonium. (Jacob's Ladder). Fine, hardy perennials.

Finest Mixed. $2 \mathrm{ft} . \ldots \ldots \ldots \ldots \ldots \ldots .0 . .0$

Potentilla. Hardy perennial, $1 \frac{1}{2} \mathrm{ft}$.

Finest Single Hybrids, Mixed.......... . Ds

Portulaca. Unrivaled for hrilliancy of color and one of the best annuals for bed. ding, etc., grows best in light sandy soil.

Double Extra Mixed. Choicest colors . .10

Single Mixed. Choicest colors; oz., .50 .05

Primula Sinensis, Chinese Primrose.

Giant Flowering. Fine Mixed. Vigorous growth, producing very large individual flowers 


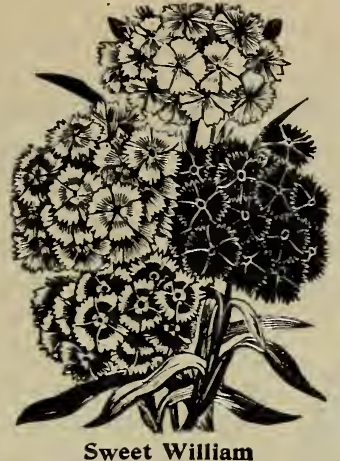

Primula-(Continued).

Double Fringed, Finest Mixed.......... .50 Auricula, Finest Mixed. Extra choice.. .10 Japonica, Finest Mixed................ .10 Veris. (Polyanthus). Large flowered.. .10 Vulgaris. True Yellow Primrcse....... .15 Obconica. Large flowering varieties; mixed colors .......................25

Passion Flower. (Passiflora). Rapid growing perennial twiners for greenhouse or sunny positions outside..............

Pyrethrum, Aureum. (Golden Feather). Golden foliage ; invaluable for bedding purposes; oz., $\$ 1.00 \ldots \ldots \ldots \ldots \ldots . .05$

Selaginoides. Fern-leaving foliage...... 10 Ricinus. (Castor Oil Plant).

Gibsonii. Dark red foliage; $6 \mathrm{ft}$; Oz.. $15 \ldots \ldots \ldots \ldots \ldots \ldots \ldots \ldots \ldots \ldots \ldots \ldots$ The handsomest and most graceful Ricinus, with foliage and stem nearly black ; 5 ft.; oz., . $20 \ldots \ldots \ldots$.

Borboniensis. Large dark green foliage ; 15 feet ; oz., .I $5 \ldots \ldots \ldots \ldots \ldots \ldots$.

Sanguineus. Blood red foliage and fruit; 7 ft.; oz., .1 $5 \ldots \ldots \ldots \ldots \ldots \ldots \ldots \ldots \ldots . .05$

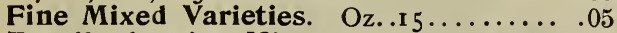

Zanzibariensis, Mixed. Gigantic leaves; the most ornamental of all; oz., .15...

Rudbeckia. (Cone Flower). A showy class of strong, easily cultivated plants.

Bicolor Superba. Similar in color and markings to the dwarf French Marigold, "Legion of Honor." $2 \mathrm{ft} \ldots . . . . .10$

Salvia. (Flowering Sage). Handsome bedding plants, with spikes of brilliant flowers. Tender perennial, blooming the first year from seed.

Splendens. Bright scarlet............ .10

Patens. Rich blue.................... 10

Bonfire. Very compact. Only $21 / 2 \mathrm{ft}$. high, produces very large scarlet flower spikes........................... .10

White........................ . 10

Silver Spot. Brilliant scarlet flowers, each leaf bearing a silver-like spot.... .15
Salpiglossis, Grandiflora. Finest Mixed. One of the most beautiful flowering plants, with very large, richly colored Petunia-like flowers, elegantly veined and pencilled.......................

Schizanthus, Finest Mixed. Beautiful and showy, hardy garden annuals; very free flowering ....................

Scabiosa. (Mourning Bride). Handsome summer flowering plants, with beautifully variegated flowers.

Tall Mixed Colors. $2 \mathrm{ft}$; oz., .30 ....... .05

Dwarf Mixed Colors. $1 \mathrm{ft}$; ; oz., . $30 \ldots \ldots .05$

Silene. (Catchfly). Free-blooming hardy plants.

Armeria. Mixed. Hardy annual; $1 \mathrm{ft} . . .05$

Smilax. A beautiful climber. Nothing can excel this plant in beauty of foliage and orange fragrance of flower; tender perennial........................

Statice. (Sea Lavender). Handsome plants with large flower heads which are everlasting; 1 to $2 \mathrm{ft}$.

Annual Varieties. Mixed.............

Perennial Varieties. Mixed............. .05

Stevia. Elegant greenhouse perennials

Lindleyana. Blush white; fragrant....

Stocks. Much admired for their magnifi-

Large Flowering Ten Weeks, Finest

Large Flowering Ten Weeks. Pure

Large Flowering Ten Weeks. Rose.... .10

Cut=and - Come $=$ Again. (Princess Alice). Pure white...................... .10

Sweet William. (See Dianthus). producng very graceful sprays of tiny. flowers, exceedingly valuable for cutting. Height, $2 \mathrm{ft}$. cent spikes of sweet scented flowers, remaining a long time in bloom, excellent for bedding or pot culture ; annual. Mixed......................... white $\ldots \ldots \ldots \ldots \ldots \ldots \ldots \ldots \ldots \ldots . .10$

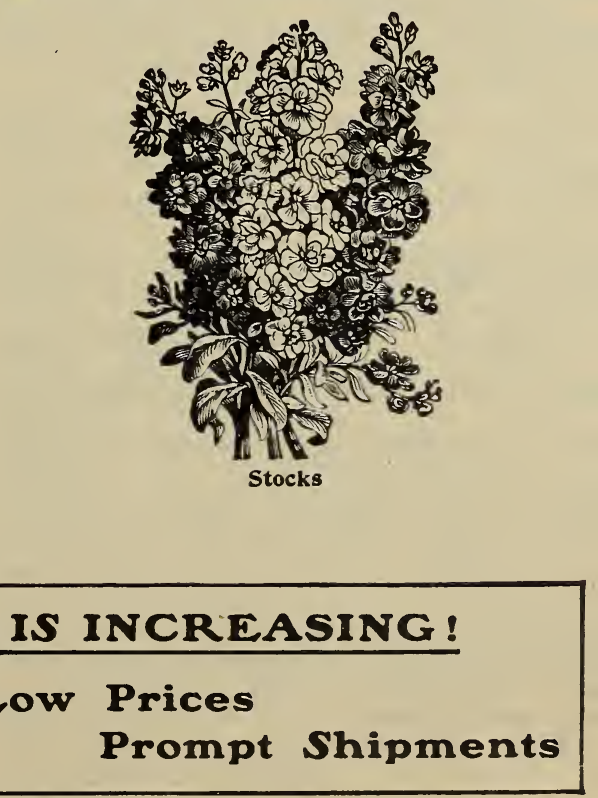

.05

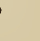

\section{Low Prices Prompt Shipments}

\section{WHY OUR BUSINESS IS INCREASING!}

\section{Fresh Seeds}

New Goods 


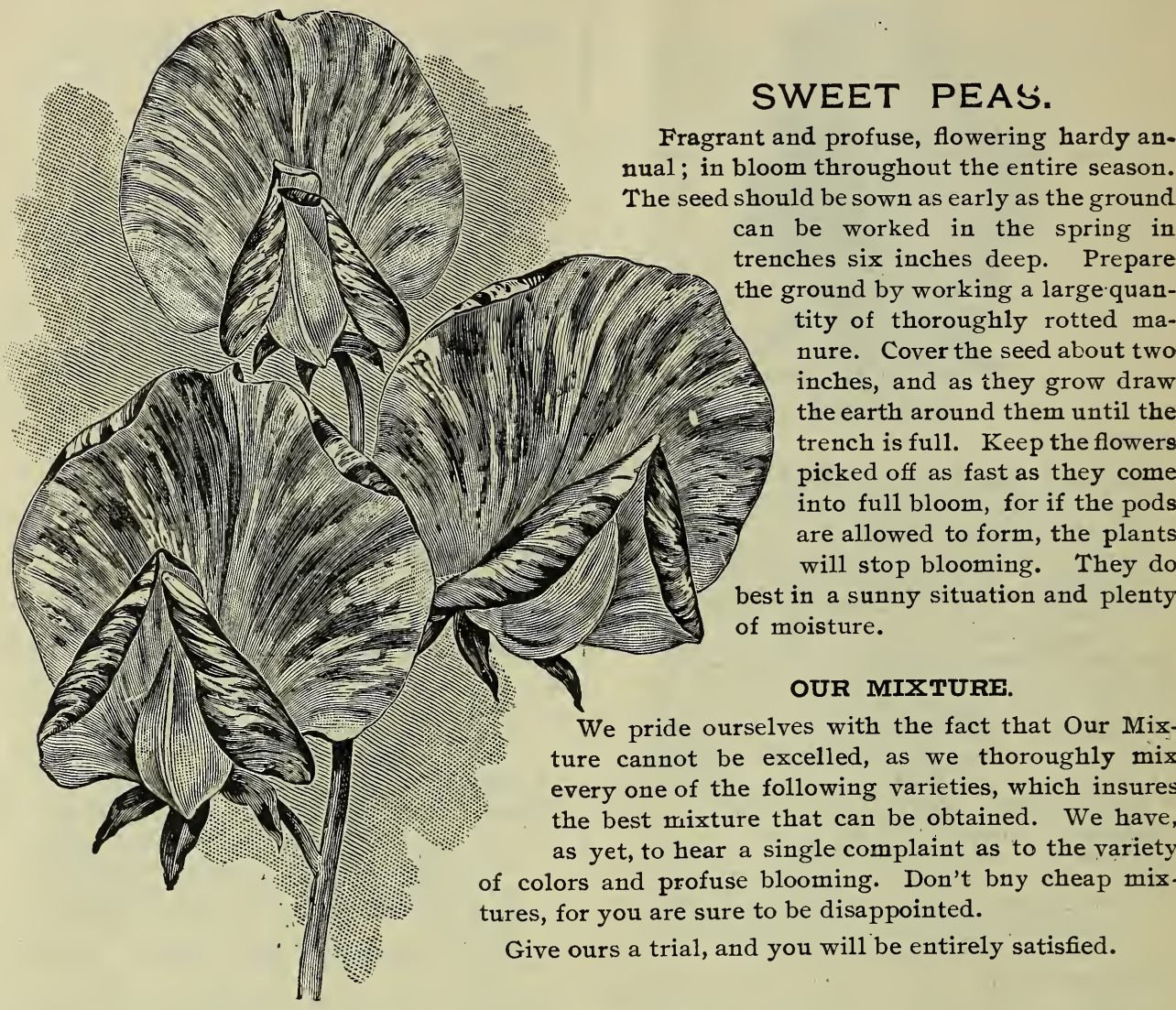

America. Crimson scarlet, irregularly striped.

Apple Blossom. Shaded pink and rose.

Black Knight. Deep maroon, clear and shining, free flowering.

Blanche Ferry. Extra early standards, a carmine pink, wings almost pure white.

Capt. of the Blues. Pale blue.

Coquette. Deep primrose, yellow shaded fawn color.

Countess of Cadogan. Bright blue.

Dorothy Eckford. The largest and best pure white.

Dorothy Tennant. Rosy mauve.

Duke of Sutherland. Deep claret standards, wings of bright indigo blue.

Eliza Eckford. Rose standards, wings striped with rose.

Emily Lynch. Deep rose pink, shaded with buff.

Emily Henderson. Pure white, good substance, long stiff stem.

Firefly. Bright scarlet.

Golden Gleam. Deep primrose yellow, the best yellow.

Gray Friar. Purple shadings on a white ground.

Janet Scott. Deep pink.

Katherine Tracy. Brilliant pink, free bloomer.

Lady Grisel Hamilton. Pale lavender.

Lady Nina Balfour. Delicate lavender, shaded with a beautiful shade of gray.
Lottie Eckford. White, shaded blue and mauve. Lovely. Soft shell pink.

Mars. Bright fiery crimson, a gorgeous flower.

Maid of Honor. Shaded light blue on a white ground, violet edge.

Mrs. Jos. Chamberlain. White striped and flecked with bright rose color.

Mrs. Eckford. Large handsome primrose colored flower.

Mrs. Dugdale. A beautiful deep rose.

Navy Blue. An entirely distinct new color (not tint), elegantly veined, nearly like deep violets.

New Countess. Both standards and wings are pure light lavender.

Othello. A beautiful dark chocolate red.

Prima Donna. Lovely shade of soft pink of large size and fine form.

Queen Victoria. Color a soft yellow, veined with faint purple, imparting a silky lustre.

Salopian. Deep crimson, suffused with rich orange scarlet.

Scarlet Gem. Brilliant scarlet.

Senator. A large gold flower, creamy ground, striped with chocolate.

Shazada. Deep maroon.

Stella Morse. Deep cream, with blush pink edge. 
Sunflower. (See Helianthus).

Swainsonia, Grandiflora Alba. Fine for house or conservatory. Graceful foliage and pure white, sweet pea-like flowers. Can be grown as a climber or trimmed into bush form. Tender perennial....

Tagetes, (Marigold). Well-known free flowering garden annuals, of rich and beautiful colors.

African. Finest dwarf, double varieties ;

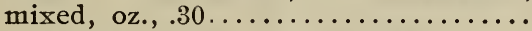

African Tall. Finest double mixed, oz., .30

El Dorado. Large double flowers in finest mixed colors; height, $2 \mathrm{ft}$., oz., .30 ...

Pride of the Garden. Large, deep golden flowers, 3 inches across, dwarf, compact habit, $1 \frac{1}{2} \mathrm{ft} . \ldots \ldots \ldots \ldots \ldots \ldots \ldots \ldots$

French. Finest dwarf double varieties; mixed ; oz., . $30 \ldots \ldots \ldots \ldots \ldots \ldots \ldots$.

French Striped. Very fine; oz., .40...

French Tall Mixed. Oz., .30.......... 05

Legion of Honor. Large single golden yellow, purple blotched, $1 \mathrm{ft} . . . . \ldots \ldots$.

Thunbergia. Rapid growing climbers; splendid for trailing over trellises, fences, etc.; height $5 \mathrm{ft}$; half hardy annuals ..........................

Torenia, Bailloni. Very pretty, free flowering trailing plants, for hanging baskets, vases, etc. Golden yellow, with brownish red throat................

Fournieri. Sky blue with bright yellow

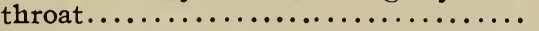

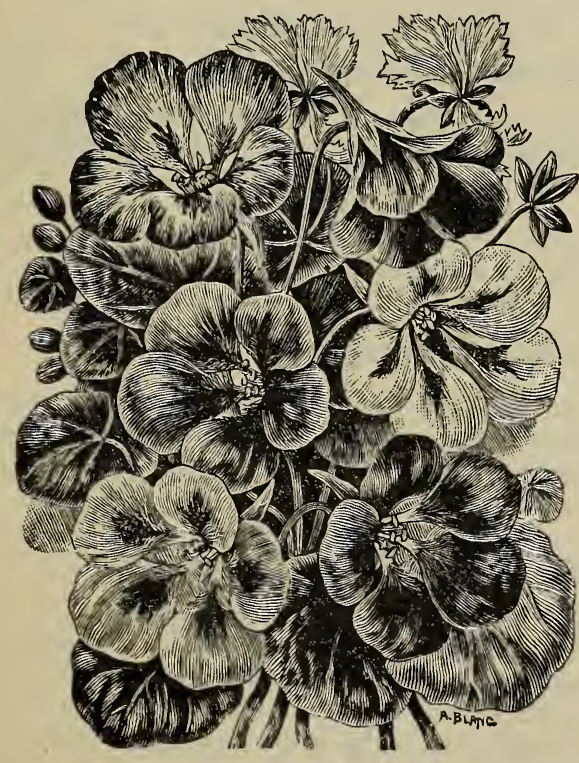

Tropæolum (Nasturtium)

Tropæolum, Canariense. (Canary Bird Vine). Bright yellow; $10 \mathrm{ft} . \ldots \ldots \ldots$.

Lobbianum. Finest mixed; splendid climbing variety, with dark foliage and handsome flowers; oz., .15...........

Madam Gunter Hybrids. A new tall variety; flowers large, rich and various coloring, darlz colored foliage ; oz., .15 ..
Pkt.

Majus, Tall Nasturtium. Beautiful freeflowering annual climbers. Flowers profusely until killed by frost. Finest Mixed, including named varieties, $1 / 4$

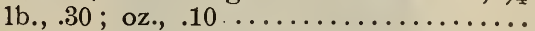

Pearl. Creamy white; oz., .15........ .05

Hemisphericum. Yellow; pink blotches; oz., .15...................... . 0

Shillingi. Bright yellow; oz., .15..... .0

Regelianum. Purple violet; oz., .15... . .0:

Coccineum. Scarlet; oz., .15.......... 05

King Theodore. Deep maroon; oz.,.15.. .05

Heinemanni. Chocolate color; oz.,.15.. .05

Von Moltke. Ruby Rose; oz., .15..... .05

Prince Henry. Pale yellow, spotted scarlet; oz., .15..................... .05

Tom Thumb, Dwarf Nasturtium. Finest mixed; $1 / 41 \mathrm{~b} ., .30 ;$ oz., .10........... .05

Beauty. Yellow, scarlet striped; oz., .15 .05

Scarlet. Oz., .15.................... .05

Spotted. Splendid; oz., .15......... .05

Empress of India. Crimson, dark-leaved variety; oz., .15...................

Aurora. New chrome yellow, spotted and veined with purplish carmine; oz., .15..........................

Cloth of Gold. Golden yellow foliage, flowers brilliant scarlet; oz., $.15 \ldots . .$.
Crystal Palace Gem. Sulphur, spotted maroon; oz., .15.................. .05

Golden King. Golden yellow; oz., .15... .05

King. Fiery scarlet, with dark foliage ; oz., $15 \ldots \ldots \ldots \ldots \ldots \ldots \ldots \ldots \ldots \ldots$...

King Theodore. Black red; oz., .15 ... .05

Lady Bird. Orange and purple spotted;

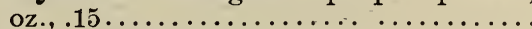

Peari. Creamy white; oz., $.15 \ldots \ldots \ldots \ldots$

Prince Henry. Pale yellow, spotted scarlet; oz., .15 ....................

Ruby King. Rose, shaded with carmine; oz., .15..........................

Verbena Hybrida. Well-known popular plants, invaluable for summer decoration, blooming the first season from seed.

Finest Mixed Mammoth. Very large and brilliant colored flowers; oz.,

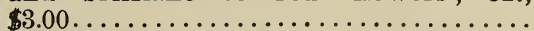

Fine Mixed. An excellent strain; oz.

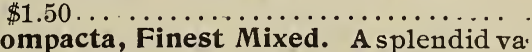
riety of dwarf, compact growth, and large, brilliant flowers...............

Giant Auricula-Flowered. Saved from the finest sorts, with large white eyes. . . .10

Candidissima. Best pure white............ 10

Corulea. Best blue shades, mixed..... .10

Coccinea. Different bright red shades... .10

Defiance. Clear, brilliant scarlet....... .10

Montana. A hardy perennial sort, with bright rose colored flowers............ 05

Veronica, Mixed. Handsome, showy flowers, hardy annual................. .

Vinca. Beautiful perennial bedding plants flowering freely the first season from seed if sown in February or March in heat, one $\mathrm{ft}$.

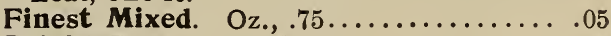

Bright Rose. Oz., $\$ 1.00 \ldots \ldots \ldots \ldots \ldots \ldots \ldots . .05$

Pure White. Oz., $\$ 1.00 \ldots \ldots \ldots \ldots \ldots \ldots .05$ 


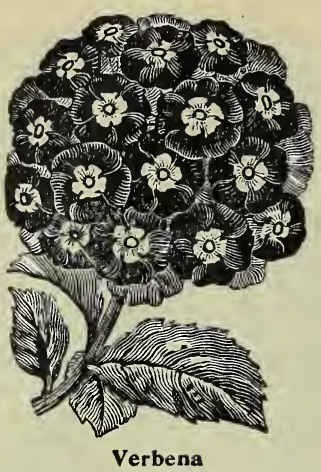

Viola Odorata (Sweet Scented Violet). A well-known fragrant plant for bedding, etc., hardy perennial; $1 / 2 \mathrm{ft} . . . \ldots \ldots . .10$

The Czar. Large flower, rich blue...... .10

Virginian Stock. Dwarf, free-flowering hardy annual; suitable for bordering and edging; mixed................05

Viscaria. - rinest mixed; showy and freeblooming hardy annuals, allied to the Lychnis; suitable for small beds and borders; $1 \mathrm{ft} . \ldots \ldots \ldots \ldots \ldots \ldots \ldots \ldots . .05$

Wallflower. A well-known plant, esteemed for its fragrance.

Finest Double Mixed Varieties.........10

Zinnia. One of the finest free-flowering plants. The flowers are large, beautifully formed, and exceedingly handsome ; annual.
Tall Double Mixed. Oz., .50 ........ .05

Tall Colors. Oz., .50 ............ 05

Dwarf Double Mixed. Oz., .50 ........05

White. Oz., $.50 \ldots \ldots \ldots \ldots \ldots \ldots \ldots \ldots .05$

Yellow. Oz., .50................ 05

Scarlet. Oz., .50 ............... .05

Purple. Oz., .50................ 05

Curled and Crested ............... 05

Xeranthemum. Finest double mixed; hardy annuals, with everlasting flowers ; colors pure white and deep purple ; 18 in........................ .

Zea Japonica Variegata (Striped Japanese Maize). Beautifully striped green and white foliage; annual; $5 \mathrm{ft} . \ldots . \ldots . .05$

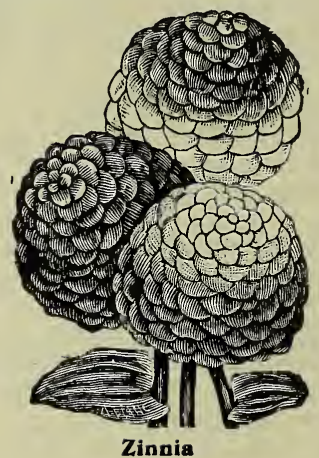

\section{FLOWER SEEDS FOR WILD GARDENS.}

Splendid Mixtures of Many Beautiful Varieties.

These Mixtures contain many beautiful and interesting Annuals, furnishing a profusion of bloom from early summer until frost. They are intended to produce a display without the care necessary to regularly kept flower beds.

Dwarf Wild Garden Flower Seeds. Half-ounce packet, .10, six for .50, postpaid.

Tall Wild Garden Flower Seeds. Half-ounce packet, .10, six for .50, postpaid.

\section{SPRING FLOWERING BULBS.}

Our illustrated catalogue of bulbs for fall planting is issued in September of each year, and malled to our customers, and to all others on application. We handle strictly first quality $\mathbf{H y a}=$ cinths, Tulips, Crocuses, Daffodils, Lilies, etc. Our prices will be as low as quality will permit.

\section{FARM AND GARDEN BOOKS.}

\section{Agriculture, A. B. C. OF. Weld . $. \$ .50 \mid$ How to Make The Garden Pay.}

CAKBAges, ON. Gregory . . . .30

CELERY FOR PRofiT. T. Greiner . . .20

Crops, Spraying. C. M. Weed . . . .25

FRUIT, THE. P. Barry . . . . 1.50

GaRdentNG FOR PleAsure. Henderson 1.50

Gardening, Success in MarkeT.

Rawson . . . . . 1.00

Greenhouse Management. Prof. L. B.

Taft : . $. \quad . \quad . \quad .50$

HOUSE PLANTS AND How TO SUCCEED

WITH THEM. Lizzie Page Hillhouse 1.00

\section{Greiner}

$\$ 2.00$

Mushrooms, How To Grow. Wm. Falconer . . . . . 1.00

MaNuRES, How To MAKE AND How To USE THEM. F. W. Sempers . . .40

PlanTS, Your. James Sheehan • $\quad .40$

PRUNING Book, THE. L. H. Bailey • 1.25

Vegetable, GaRdening. Prof. S. B. Green $\quad . \quad$. $. \quad . \quad 1.25$

WEEDS, How TO ERADICATE THEM. Professor Shaw . $\quad . \quad . \quad .75$

Young Marke'T Gardener, THE 。 0 


\section{Summer and Autumn Flowering Bulbs.}

\section{BEGONIA, Tuberous-Rooted.}

For bedding and as pot-plants, these beautiful flowers are very desirable and popular. They bloom continuously all summer, flowers very large, and outrivaling those of the most brilliant Geraniums. The flowers are circular, large, and of great substance; the colors are most beautiful, rich and varied.

\section{SINGLE FLOWERING VARIETIES.}

Rose, Scarlet, White, Yellow and Orange .............. .05

Finest Mixed. From above sorts.................... .05
Doz. Per 100

$.60 \$ 4.00$

$.50 \quad 3.50$

\section{DOUBLE FLOWERING VARIETIES.}

Red, Rose, White and Yellow Each Doz.

Finest Mixed. From above sorts..................

\section{$.10 \$ 1.00$}

$.10 \quad 1.00$

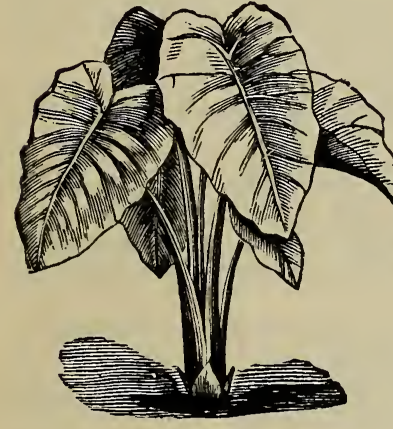

Caladium

\section{CALADIUM ESCULENTUM,} Elephant's Ear.

Very ornamental, with immense smooth, light green leaves, beautifully veined with dark green. One of the most effective plants in cultivation for the flower-border or lawn; will grow in any good garden soil, and is of easiest culture. To obtain the best results, should be planted where it will obtain plenty of water, and in an abundance of rich compost.

\begin{tabular}{|c|c|}
\hline Monster Bulbs.... & $\begin{array}{r}\text { Each } \\
.25\end{array}$ \\
\hline Extra Large Bulbs & .15 \\
\hline
\end{tabular}

\section{CANNA ROOTS.}

Alsace. White $; \frac{1}{2} \mathrm{ft}$.

Chas. Henderson. Crimson; $4 \mathrm{ft}$.

Flamingo. Scarlet; $4 \mathrm{ft}$.

Florence Vaughan. Yellow, spotted crimson; $6 \mathrm{ft}$.

Madam Crozy. Scarlet, yellow border; $3 \frac{1}{2} \mathrm{ft}$.

Shenandoah. Rose; dark foliage; $3 \mathrm{ft}$.

Robusta. Scarlet; dark foliage ; $8 \mathrm{ft}$.

A11 varieties, each, $.10 ;$ doz., .75.

\section{DAHLIAS.}

The principal requirement of the dahlia is a sunny location, with ordinary soil. The ground should be thoroughly cultivated with a spade or plough from eight to ten inches deep. The dahlia, when planted, should be laid flat down, with the crown where the sprout is, about six inches deep, with a liberal supply of any kind of dressing or fertilizer; it is well to cover the bulb an inch or more with soil before using your dressing or fertilizer; this will keep the sprout from getting injured. Dahlias, when grown, should be either staked or the single branching method used; when the plant gets two sets of leaves and an undeveloped growth on the top it is pinched back as far as the upper leaves; four branches will then start, one at each leaf, and this saves staking. When the plant is grown it will have a short, strong, single stem, which comes only an inch or two above the ground, and four branches which are strong enough to hold themselves up without staking, giving the plant a neat branching appearance. Dahlias should be planted from three to five feetapart, allowing but one or two stalks to grow, and ground thoroughly cultivated and kept free from weeds. They are one of the easiest plants to grow, producing more flowers than any other plant in the garden. If planted before May 30th will flower by the last of July or the middle of August, and continue until killed by the frost.

We carry in stock a large number of the leading varieties and can also supply any variety not in stock. 


\section{GLADIOLUS.}

A search, be it ever so painstaking and complete, of the floral kingdom, will discover no flower of such easy culture embracing the great range of color with endless combinations and variety,

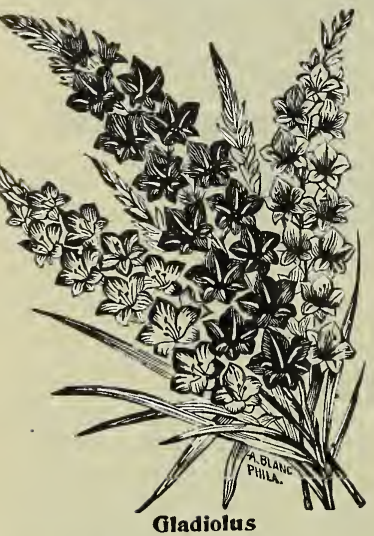
to equal the Gladiolus. Although called the people's flower, it to-day is practically unknown to both the amateur and average grower, and we claim for the newer hybrids greater beauty and more exquisite coloring than in any other garden ornament. Even the orchids failed to equal it, excepting in durability as a cut flower, and here the Gladiolus excels all others.

For the best results, cut the spike when the first flower opens and bloom in the house. This treatment is also beneficial to the bulb.

Varieties of the Gladiolus are now numbered by thousands, but comparatively few possess sufficient vitality to reproduce characteristic flowers; the same may be said of self-fertilized seedlings. This makes our selected collections of special value and advantage to the buyer. The process of selection also assures the best possible results in the hybridized seedlings listed herein.

The soil should be rich, thoroughly forked, cultivated and well drained. The bulbs should be planted four inches deep and about six inches apart.

Our mixtures are made up from fine varieties, and are all selected first size bulbs, and are sure to give the best results.

Groff's Silver Trophy Strain. This magnificent strain has a world-wide reputation and represents the cream of Groff's creations. It has been divided in to three color sections, which we offer separate or mixed, viz. :

Section No. 1. This contains all the scarlet, blood-red, garnet, amaranth, and similar rich shades of color in great diversity. 6 cts. each ; 60 cts. per doz.; $\$ 4.00$ per 100 .

Section No. 2. This is composed of the white, yellow and delicate shades of pink, rose, etc., and is especially valuable for cutting. $7 \mathrm{cts}$. each ; 65 cts. per doz.; $\$ 5.00$ per 100 .

Section No. 3. In this section are included the new blue, purple, heliotrope, lilac, mauve and similar tints. A lady customer on seeing a bunch of these called them " pansy colors." They are for the most part entirely new and distinct. $8 \mathrm{cts}$. each; $80 \mathrm{cts}$. per doz.; $\$ 6.00$ per 100 .

Gold Medal and Silver Trophy Mixture. This contains some each of the above three sections, and so great is the diversity in color that customers run practically 1 o risk of getting any two alike; by far the finest mixture of Gladioli ever offered. 7 cts. each; 65 cts. per doz.; $\$ 5.00$ per 100 .

Groff's Hybrids. This is the earlier hybrids of Mr. Groff, and while not as fine as the preceding, the size and coloring of many of the sorts are truly marvelous. 4 cts. each; $30 \mathrm{cts}$. per doz.; $\$ 2.00$ per 100 .

Lemoine's Butterfly. Hybrids, Mixed. The remarkable richness of the colorings of this class rival the finest orchids. 30 cts. per doz.; $\$ 2.00$ per 100 .

American Hybrids. This is our leading general mixture, and is composed of fine sorts in all colors, in first-size bulbs only. 30 cts. per doz.; $\$ 2.00$ per $100 ; \$ 15.00$ per 1000 .

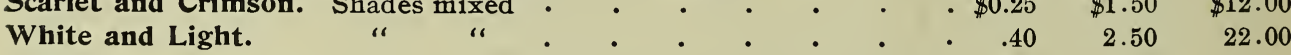

Yellow.

Striped and Variegated.

Pink.

66 Arthur Cowee, the famous specialist, who is, without doubt, the largest and most careful grower in the United States. 


\section{GLOXINIAS.}

Magnificent for house culture, producing in great profusion beautiful flowers of the richest and most beautiful colors. They succeed best in sandy loam and peat, and require a moist heat. After blooming dry off gradually, let the bulb remain in the pot without water, and keep in a warm place until they show signs of starting again.

Large Flowering Varieties, Separate colors. .10 each; $\$ 1.00 \mathrm{doz}$.

Large Flowering Varieties, Finest Mixed. In many beautiful colors; 10 each; .75 doz.

\section{HYACINTHUS CANDICANS.}

A snow-white summer flowering Hyacinth, growing 3 to 5 feet in height, gracefully surmounted with from 20 to 30 pure white bell-shaped flowers; .05 each; .50 doz.

\section{LILIES.}

No class of plants can lay so much claim to our attention as the Lilies. They are stately, elegant and beautiful, and possess the most agreeable perfume, and for general effect, whether growing in garden or house, they have no rivals. The soil should be rich, deep and mellow, with good drainage, as nothing will injure the bulbs more than water collecting and standing around them. Do not put manure about the bulbs when setting, as it collects moisture and insects, and often causes the bulbs to decay. Top dressing is the better way to enrich the soil after the bulbs are set. The beds should be well covered with leaves and strawy manure to exclude the frost. Set bulbs 4 to 6 inches deep according to their size.

Auratum, (Golden Banded Lily of Japan). Immense white flowers, each petal Each. Doz.

marked with wide gold band and spotted with maroon................ $\quad .15 \quad \$ 1.50$

Speciosum (Lancifolium) Album. Pure white, fragrant; very hardy......... . . . $\quad 1.50$

Speciosum Roseum. White, spotted rose, splendid bulbs . . . . . . . . . . . . . . . .15 1.50

Speciosum Rubrum. White, spotted crimson, splendid ............... .15 1.50

Tigrinum Splendens (Tiger Lily). Rich scarlet with black spots . . . . . . . ... $\quad .10 \quad 1.00$

Tigrinum Flore Pleno. Double, very fine..............................

\section{MADEIRA VINE.}

A rapid-growing vine, covering a large space in a short time. Fleshy heart-shaped leaves of a light green, and numerous racemes, of feathery flowers of delicious fragrance. A beautiful and popular line: 05 each; .40 per doz.

\section{MONTBRETIAS.}

The Montbretias are one of the brightest and best of summer-flowering bulbs. The bulbs should be planted from April to June in clumps or groups of three to a dozeu or more. They are perfectly hardy, and once planted can be left to care for themselves. In growth they resemble the Gladiola, and produce spikes of the most brilliant flowers in the various shades of orange, yellow, red, etc.

We offer the following varieties:-

Aurea. Deep yellow, trumpet shaped.

Crocosmiaeflora: Deep golden-orange; fine.

Etoile de Feu (Fiery Star). Deep brilliant scarlet throughout.

Elegans. Outside yellow and crimson, inside pure yellow.

Tigridie. Deep tawny yellow, a crimson blotch at the base of each segment.

Transcendent. Broad orange petals, golden centre.

Price of any of the above .05 each; .30 per doz.

\section{$P$ PONIES.}

We can furnish these well-known old favorites in all the newest varieties : Hardy Herbaceous Varieties Named. .50 each.

Hardy Herbaceous Large Roots. Various colors, mixed, .25 and .50 each.

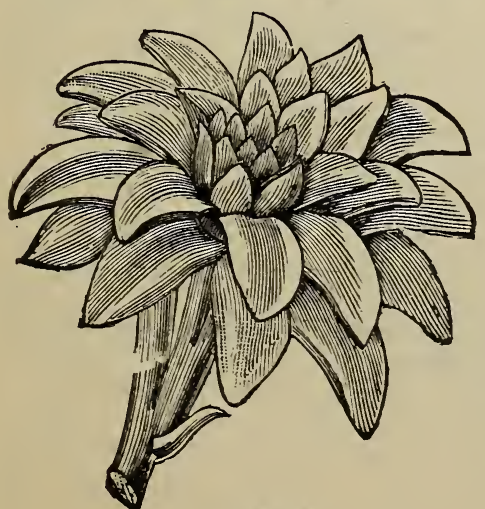

Tuberose

\section{TUBEROSES.}

One of the most delightfully fragrant flowers. Invaluable for bouquets, botton-holes and wherever cut flowers are in demand. Before potting the bulbs remove the small offsets.

Excelsior Double Pearl. A superior strain with very large white flowers, produced in great abundance. Per doz., .25 ; per $100 \$ 1.50$.

The fact that we have supplied the leading Market Gardeners with their Vegetable Seeds and the leading Florists with their Flower Seeds for many years, ought to be a sufficient guarantee as to the quality of our seeds to the most critical. Try us one year and be convinced. 


\section{Fertilizers.}

Prices Subject to Change.

Pulverized Sheep Manure. The richest natural manure, and the most nutritious food for plants. Its effect is immediate, much more lasting and healthy than guano or any other manure. It is the best manure for mixing with the soil for greenhouse plants. It makes the richest, safest and quickest liquid manure, rivaling guano without any deleterious effects.

Directions. For mixing with soil, use 1 part manure to 6 parts soil. For making a liquid, use 1 pound manure to 5 gallons of water.

Price per bag, $\$ 2.00$; 10 1bs., .50; 5 1bs., . 30 ; 2 lbs., .15.

Canada Unleached Mardwood Ashes. As a fertilizer for lawns and gardens hardwood ashes are unequalled; they supply natural plant food, permanently enriching the soil. One of the best for lawns, giving the grass a rich, dark shade of green, and destroying many of the insects which are so injurious to grass, roots and leaves. Price per 100 1bs., $\$ 1.00$; ton, $\$ 18.00$.

Bowker's Hill and Drill Phosphate. A concentrated general fertilizer used either alone or with manure. This phosphate is made, as its name implies, for the hill or drill or for broadcast sowing. It is composed principally of bone, thoroughly dissolved so as to make it active in all stages of plant growth. Per bag 100 1bs., $\$ 2.00 ; 501 \mathrm{~b}$. bag, $\$ 1.00$.

Stockbridge Special Manures. They were the first special manures introduced in the country, and are founded on the principle of supplying the crop, in suitable proportion, with that plant food which it requires. The following are the leading brands: Potato, Corn and Grain, Grass Top Dressing, Small Fruits, Vegetables, Root Crops and Celery. Price, $100 \mathrm{lb}$. bag, $\$ 2.25$; ton, $\$ 40.00$.
Bowker's Lawn and Garden Dressing, Pre= pared for Lawns, Gardens and Flower Beds. This dressing is prepared from chemicals, free from weed seeds, nearly odorless, clean to handle and easily applied. It acts gradually through the season, and produces a luxuriant growth of grass of a rich green color. It is also a superior dressing for the flower garden.

$10 \mathrm{lb}$. bag for 1,000 square feet........\$ .50

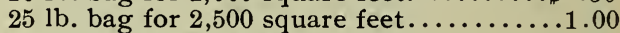

$50 \mathrm{lb}$. bag for 5,000 square feet .......... 50

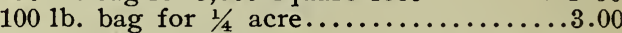

Bowker's Ammoniated Food for Flowers. Soluble in water. A fertilizer made from chemicals and prepared especially for plants grown in the house, garden or conservatory; clean, odorless, and producing early and abundant blossoms of rich and brilliant color, and healthy, luxuriant plants.

Directions for use with each package.

Small package, .15; large package, .25.

Bradley's Superphosphate. A well-known brand of fertilizer for general use on all farm and garden crops. Price, 100 lbs., $\$ 2.00$.

Pure Ground Bone. This is a very pure, finely pulverized form of ground bone, especially prepared for rose culture, top dressing for lawns and for potted plants. Price, $5 \mathrm{lb}$. package, .25; per 100 lbs., $\$ 1.75$.

" Sterlingworth" Plant Food, Tablet Form. A new, scientific, odorless food for potted plants. Makes plants grow and bloom luxuriantly, and drives troublesome insects from the soil. Small box, contains sufficient food for 10 ordinary house plants for three months, .10; large box, contains enough for 40 plants for three months, .25.

\section{CHEMICALS.}

Dissolved Bone. 2 to 3 per cent. ammonia, 12 to 14 per cent. phosphoric acid............\$1.75

Dissolved Bone, Black. 15 to 18 per cent. phosphoric acid......................... 1.50

Plain Superphosphate. 12 to 14 per cent. phosphoric acid........................ 1.00

Nitrate of Soda. 95 to 98 per cent. purity; 18 to 19 per cent. ammonia. $51 \mathrm{bs} ., .30 ; 101 \mathrm{bs}$,

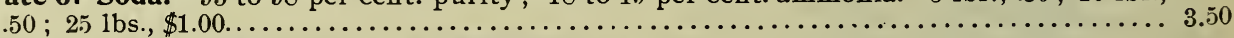

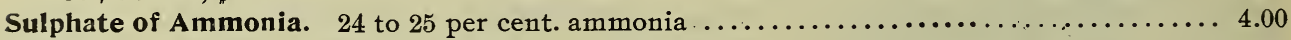

Dried Blood. 10 to 12 per cent. ammonia........................................ 2.50

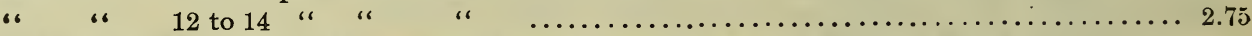

Muriate of Pota $=$ h. 80 to 85 per cent.; 50 to 52 per cent. actual potash. 101 bs., .50...... 2.50

Double Sulphate of Potash and Magnesia. 48 to 52 per cent. sulphate of potash; 35 to 40

per cent. sulphate of magnesia ; 26 to 28 per cent. actual potash.................. 2.00

High Grade Sulphate of Potash. 90 to 95 per cent. sulphate of potash; 48 to 52 per cent.

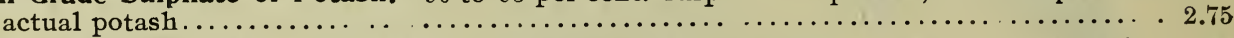

Kainit. 23 to 25 per cent. sulphate and muriate of potash; 12 to 13 per cent. actual potash.. 1.00

Sulphate of Magnesia. 50 to 55 per cent. sulphate magnesia..................... 1.50

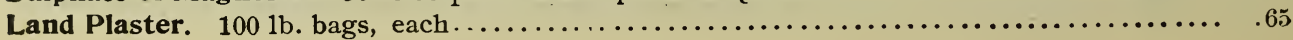




\title{
Insecticides.
}

\author{
Prices Subject to Change.
}

Ant Exterminator. For the destruction of ants in lawn and pleasure grounds. Directions for use on each package. Put up in three sizes, .30, .60, $\$ 1.00$.

Bordeaux Mixture. A valuable and indispensable fungicide for grape growers. It prevents potato blight, mildew, black rot, etc. To every one gallon of mixture add 49 gallons of water. Price, 1 gallon can, $\$ 1.00$; 1 quart can, .40 ; pint cans, .20 .

I. X. L. Lice Powder. A cheap and effective remedy for all kinds of poultry vermin, lice on cattle, horses or plants. Directions on each package. Each, .25, .50, $\$ 1.00$.

Fir Tree Oil, Soluble. For destroying all insects and parasites that infest plants, without injuring the plants. It is also an excellent wash for dogs and other animals, and is harmless to the hands and skin. Directions with each package. $1 / 2$ pint, .40 ; pint, .65; quart $\$ 1.15$; gallon, $\$ 4.00$.

Flour of Sulphur. A preventative and cure for mildew on grape vines, rose bushes, etc. Apply with powder gun or bellows. Per 1b.,.06; 5 1b. package, .25; 10 1b. package, .50.

Kerosene Emulsion. Ready for use by simply adding water (20 to 50 parts water to one of emulsion). For cabbage worm, scales on trees, melon louse, and all sucking insects. Price, quart can, .40; pint cans, .20 .

California Wash, Concentrated, Lion Brand (lime, sulphur and salt). For the destruction of San Jose scale, etc. Quart .40; gallon, $\$ 1.00$.

Nikoteen. A liquid insecticide for spraying or vaporizing. Specially prepared for use in greenhouses. $1 / 2$ pint bottle, .75 .

Grape Dust, Hammond's. For the prevention of mildew on roses, grapes, etc. It is not only a preventative, but it cures plants already affected. Apply with bellows. Price, 5 1b. package, .35.

"Sterlingworth" Weed Killer. A powerful and effective compound which destroys in 12 to 72 hours weeds, grass (including milk weed and witch grass), burdock, poison ivy, dandelions, daisies and all other obnoxious vegetable growths. Prices: 1 lb. package, makes 15 gals., .50; $31 \mathrm{~b}$. package, makes 45 gals., $\$ 1.25 ; 51 \mathrm{~b}$. package, makes $7 j$ gals., $\$ 2.00$.

Hellebore. (Strictly pure.) One of the best insecticides for the destruction of rose slugs, currant worms, etc. Dust on with powder gun or bellows. Price, $1 / 4 \mathrm{lb}$. package, $.10 ; 1 / 21 \mathrm{~b}$. package, .15; per pound, .25 .

Cypher's Anti=Fly Pest. A preparation guaranteed to keep flies away from cattle and horses. May be applied with a brush or hand sprayer. Price, .75 per gallon; .50 per $1 / 2$ gallon.
London Purple. Per pound box, .20.

Nikoteen A phis Punk. A preparation of Nicotine in most convenient form for killing insect life on plants and flowers, without injuring the most sensitive bloom or foliage. Price, per box 12 rulls, .60.

Paris Green. This poison is more universally used for the destruction of potato bugs than any other. Per pound, .35.

Scalecide. The best spray for San Jose scale and all other soft-bodied insects. Mixes instantly in cold water and stays mixed. For fall, winter and early spring spraying, use 1 part Scalecide to 15 parts of water. Qt., .40 ; gal. can, $\$ 1.00$; 5 gal. can, $\$ 3.25$. powder and a very popular insecticide, destroys insects injurious to house and garden plants. 5 1b. package, .25; $101 \mathrm{~b}$. package, .50.

Sulpho=Tobacco Soap. For destroying rose slugs, green $\mathrm{fy}$, lice, and eggs of insects. Price, in tin box, with directions, sufficient for five gallons of water, .10 and .20.

Tobacco Dust. Kills black and green fly, etc. Spread upon the ground it keeps off all earth insects, and also acts as a fertilizer. Apply with powder duster or bellows. Per 1b.,.10; 5 lb. package, .25; per 100 lbs., $\$ 3.00$.

Tobacco Stems. For fumigating greenhouse, for the destruction of green fly and other insects. Dampen before lighting. Per bale, 100 lbs., $\$ 1.50$.

Whale Oil Snap. Effective in destroying insects and lice on plants, trees, etc.; $1 \mathrm{lb}$. box, .15; 2 lb. box, .25.

Bug Death. It is sure death to potato, squash, and cucumber bugs, currant and tomato worms, etc.; also prevents blight on potato vines. Safe to handle. It is applied dry, and will not blow or wash off. Lb.,.15; 3 lbs., .35; 5 lbs., .50 ; 121/2 1bs., $\$ 1.00$.

Shakers for Bug Death. .25 each.

Bowker's Boxal. Remedy for all insects and diseases which attack the potato. $5 \mathrm{lb}$. cans, $\$ 1.00$.

Bowker's Disparene. Kills elm-leaf beetle, tussock moth, cut worm, gypsy moth, etc.; does not burn the leaves and adheres throughout the season. 2 1b. cans, .40; 5 lb. cans, . 90 .

Bowker's Pyrox. A practical remedy for mil. dew, scab, rot, rust, etc.; destroys the codling moth, canker worm, tent caterpillar and allied pests. $5 \mathrm{lb}$. cans, $\$ 1.00 ; 10 \mathrm{lb}$. cans, $\$ 1.75$.
Slug Shot (Hammond's). A non-poisonous 


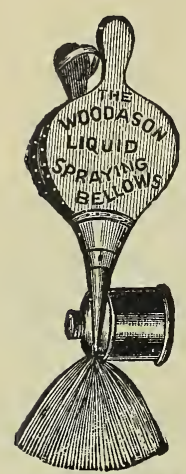

Liquid Bellows

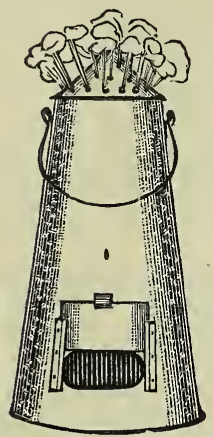

Eureka Fumigator

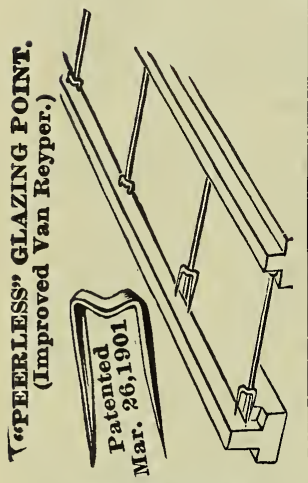

Glazing .Points

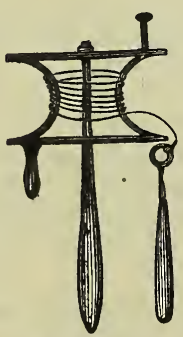

Garden Reel
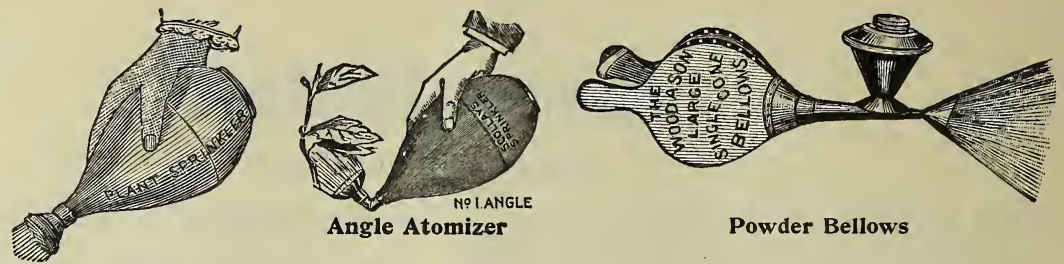

Powder Bellows

Atomizer

Axes, Handled. .75 to $\$ 1.25$.

Atomizers. Scollay's, No. $1, .80$; No. 2 , .75; No. $3, .60$; No. $4, .50$; Angle, .80 ; Acme (tin), .50.

Baskets. Verbena, sma11, $\$ 2.00$ per 100 ; large, $\$ 3.00$ per 100 .

We also have all other kinds of Baskets.

Bellows. Woodason's Large Single Cone, $\$ 2.00$; Small Single Cone, $\$ 1.00$; Large Spray, $\$ 2.00$; Small Spray, $\$ 1.25$.

Bill Hooks. English, $\$ 1.25$.

Bush Hooks. $\$ 1.25$.

Butter Color. Wells, Richardson \& Co.'s, .25 and .50.

Buckets, Well. Galvanized Hoop, .75; Bates', $\$ 2.00$; Valve, $\$ 1.00$.

Brooms, Stable. Upright Rattan, .60; Rattan and Corn mixed, .50.

Churns, Cylinder. No. $1, \$ 2.25$; No. $2, \$ 2.75$; No. $3, \$ 3.25$.

Dibbers. Iron Point, .35.

Diggers. Clan, .55; l'otato, 5 tines, .55; 6 tines, .65; Post Hole (Gibbs), \$1.25.

Edging Knives. (E1y), .50.

Feed Bags. Genuine Whitaker, .85; Whitaker Pattern, .70.

Flails. (Torrey's), .60.

Forks. Transplanting, .20 and .30 ; Spading, plain, .75; strapped, .80 ; Manure, 4 tines, .65 ; 5 tines, $.80 ; 6$ tines, .90 ; Hay .25 to .50 ; Wood Stable, .50; Grapple Horse Hay, 4 tines, $\$ 5.00 ; 6$ tines, $\$ 6.00$; Double Harpoon Horse Hay, \$1.75; Single Harpoon Horse Hay, $\$ 3.50$.

Fruit Pickers. .25.

Food, Spratt's Dog. Used by the leading kennel owners and breeders in the world. Fed exclusively at the principal dog shows.

Dog cakes: $31 \mathrm{~b}$. cartons, 25c; $251 \mathrm{bs} ., \$ 1.75$;

50 lbs., $\$ 3.25 ; 100$ lbs., $\$ 6.50$.

Puppy cakes: 21/2 1b. cartons, .25; 25 1bs., $\$ 1.90$; 50 1bs., $\$ 3.50 ; 100$ 1bs., $\$ 7.00$.

Garden Lines, Braided. $100 \mathrm{ft}$. lengths, .50 ; $50 \mathrm{ft}$., .30.

Garden Reels. Large iron, .50.

Grease, Axle. Snowflake, 1 qt., .20; 2 qts., .35; 1 gal., .65; Frazer's, box, .12; 15 1b. pail, $\$ 1.00 ; 251$ b. pail, $\$ 1.50$.

Garden Sets. 3 pieces, $.75 ; 4$ pieces, $\$ 1.00$.

Glazing Points. Peerless (Improved Van Reyper). No. 2 for medium double thick glass; No. $2 \frac{1}{2}$ for large double thick and skylight glass. Price, either size, per $1,000, .60$; pincers for driving, .50.

Grass Catchers. For any style mower (state size of machine), $\$ 1.00$.

Grass Hooks. English, No. 2 , .35; No. $3, .40$; No. 4,.45; American .25 to .35 . 


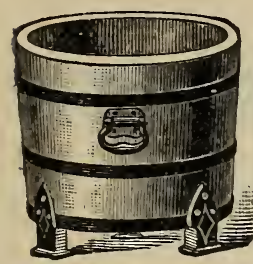

Plant Tub

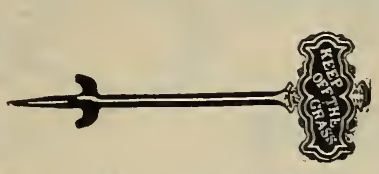

Keep Off The Grass

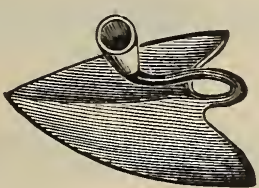

Warren Hoe

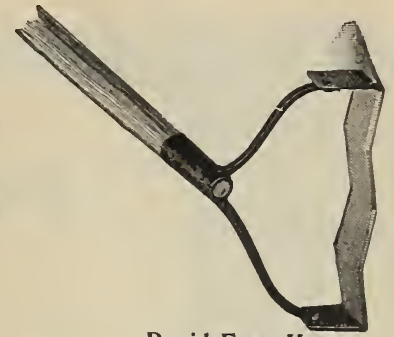

Rapid Easy Hoe
Grafting Chisels. .50.

Grafting Wax. 1/4 1b., .10; $1 / 2$ 1b., .15; 1 1b., .25.

Grindstones. Nova Scotia, mounted on strong frames, 20 ins., $\$ 5.00$; 25 ins., $\$ 7.00 ; 30$ ins., $\$ 8.00$.

Hose, Rubber. Service warranted for one year. $1 / 2$ in., .11 per ft.; $3 / 4$ in., .13 per ft.

Hose Nozzles. Deming Vermore1, .75; Bordeaux, .75; Boston Spray .50 ; Fairy, .50.

Hose Couplings. Brass, $\frac{1}{2}$ in. and $3 / 4$ in., per pair, .20.

Hose Menders. Hudson's, 6 tubes, 20 wires and pliers, .60 per box; bands, .15 per doz. ; tubes, .36 per doz.; Cooper's, $1 / 8$ in. or $3 / 4$ in., .10 each; $\$ 1.00$ per doz.; Simplex, $1 / 2$ in. or $3 / 4$ in., .05 each; .50 per doz.

Hose Reels. See page 40.

Hotbed Mats. Palmer's Burlap, $76 \times 76$ in., $\$ 1.15$; Burlap and Duck, $\$ 1.46$.

Hoes. Field and Garden, .25 to .45; Warren, Humphrey and P1ympton, .65; Dutch Scuffle, 6 in., .50; 7 in., .55; 8 in., .65 ; 9 in., .75; American Scuffle, 6 in., .20; 7 in., .25; 8 in., .30; 9 in., .35; Arlington Scuffle, $\$ 1.40$; Rapid Easy Scuffle, .50; Billings' Bog, $\$ 1.00$; Adze Eye Bog, .65.

Holders, Bouquet. Iron, for cemetery use, .25 and .30.

Jacks, Wagon. Leader, No. $1, \$ 2.50$; No. $2, \$ 1.50$.

Keep off the Grass Signs. Iron, 26 in. long, .50 .

Kegs. Oak, 5 gal., $\$ 1.00 ; 10$ gal., $\$ 1.30 ; 15$ gal., $\$ 1.85 ; 20$ gal., $\$ 2.15$.

Knives. English Budding. $\$ 1.25$ and $\$ 1.50$; English Pruning, $\$ 1.25$ and $\$ 1.50$; Lightning Hay, $\$ 1.00$; Corn, .20 and .30; Asparagus, .25.

Mastica. For glazing Greenhouses, Sashes, etc., 1/2 gal., .65; 1 gal., $\$ 1.25$.

Mastica Machine. For applying Mastica, $\$ 1.25$.

Mattocks. With Cutter, .75; with Pick, .75.

Measures. Varnished, 1 qt., $.12 ; 2$ qts., $.18 ; 4$ qts., $.30 ; 1$ pk., .35; $1 / 2$ bush., .75 . Set of $5, \$ 1.40$.

Milk Tubes. Composition, .25; Genuine Silver, .50.

Mowers, Lawn. See pages 41,42.

Oil. Machine, for all kinds of implements, $1 / 2$ gal., .50; 1 gal., .75; Climax, qt. cans, .30 .

Oilers. .10 to .25 .

Paper. Tissue, .05 per quire; Wax, $12 \times 18$ in., .05 per quire; Butter, .18 per $1 \mathrm{~b}$.

Palls. Stable, Pine, .25; Heavy Oak, .60; Galvanized Iron, .25 to .50; Fibre, 12 qts., .25.

Pencils, Indelible. .10.

Picks. Chisel Pointed, 7 lbs., .75; Contractor's, 8 to 9 lbs., .80 .

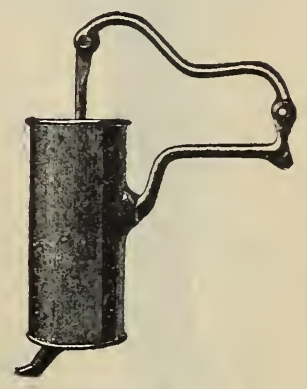

Mastica Machine

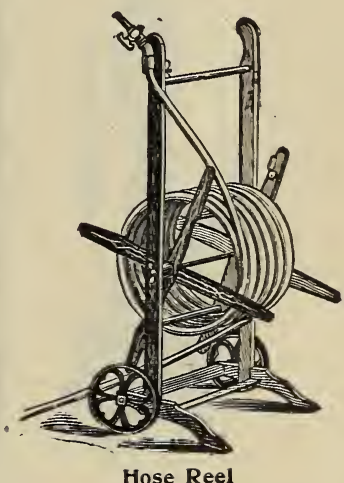

Hose Reel

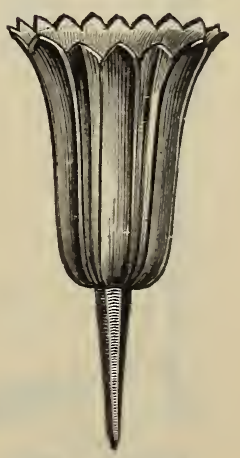

Bouquet Holder 


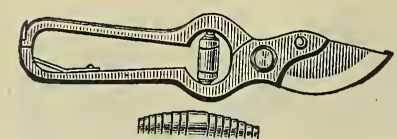

Pruning Shears

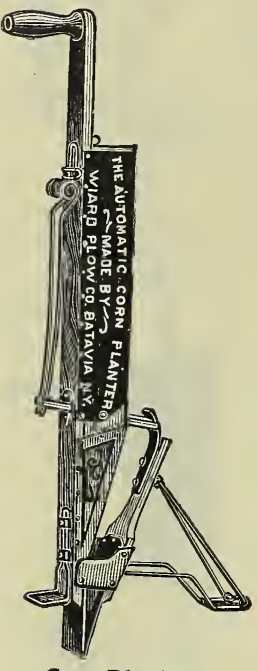

Corn Planter
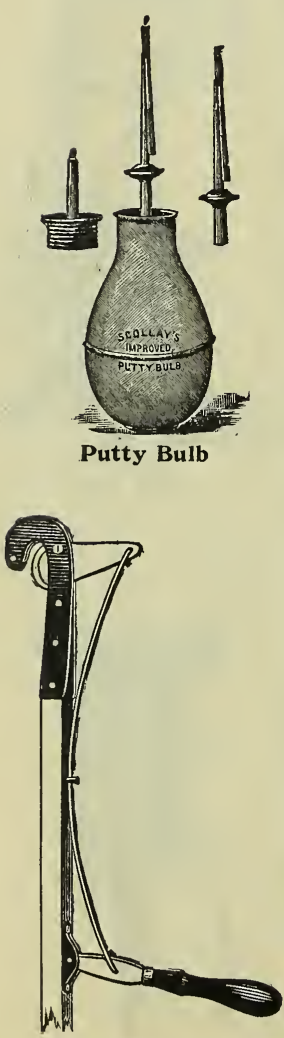

Waters' Pruner
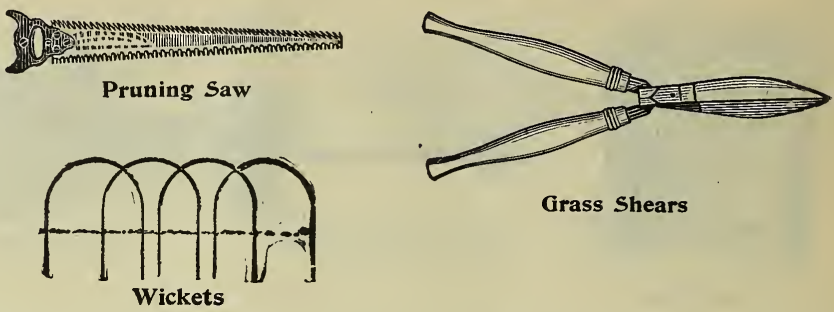

Grass Shears

Planters, Hand Corn. Wiard, $\$ 1.75$; Segment, $\$ 1.25$.

Plant Protecting Cloth. A cheap substitute for glass. Heavy, .121/2. per yard.

Putty Bulbs. Scollay's, $\$ 1.00$.

Plant Tubs. Cypress. Painted green, drop handles. Bound with extra heavy hoops. No. 1, 11 in. diameter, 13 in. high, $\$ 1.25$; No. 2, 13 in. diameter, $14 \frac{1}{2}$ in. high, $\$ 1.50$; No. 3,15 in. diameter, 16 in. high, $\$ 1.75$; No. 4,18 in. diameter, 20 in. high, $\$ 2.25$.

Rakes. Stee1 Garden and Lawn, 12 teeth, .45; 14 teeth, .50; 16 teeth, .55 ; Wood Lawn, .50; Hay, .20 to .40; Drag or Bull, .75.

Raffia. Per 1b., .20.

Saws, Buck. Disston's, No. 50, $\$ 1.00$; Double Edge Pruning Saws, 16 in., $.65 ; 18$ in., .75.

Scissors. Grape Vine, 6 in., .85; 7 in., .95; Bow, 6 in., $\$ 1.25$; Flower Gatherers', \$1.10.

Seed Sowers. Cahoon's Broadcast, $\$ 3.50$.

Scrapers, Tree. Steel blade, .35; Heavy, .50.

Scythes. Little Giant, double back, .85; India Stee1, .75; Clipper, .75 ; English Lawn, $\$ 1.50 ;$ Bush and Bramble, .75.

Scythe Snaths. Grass, .70; Bush, .75.

Scythe Stones. Round English, .20; American, .05 and .10 .

Shears. English Grass, 8 in., $\$ 1.10 ; 9$ in., $\$ 1.25 ; 10$ in., $\$ 1.50$; Eng. lish Hedge, 8 in., $\$ 1.20 ; 9$ in., $\$ 1.40 ; 10$ in., $\$ 1.65$; Long Handle Border, 9 in., $\$ 1.80$; 10 in., $\$ 2.50$; with wheels, 9 in., $\$ 2.75$; 10 in., $\$ 3.25 ; 6$ in. Ladies', $\$ 1.00$; Sheep, for cutting grass, .50 and .75 ; Pruning, French, 8 in., $\$ 1.00 ; 9$ in., $\$ 1.20 ; 10$ in., $\$ 1.40$; No. 61, German Volute Spring, .85; Taylor Pattern, Volute Spring, .50.

Shellers, Corn. Red Chief, $\$ 2.00$; Penn., with separator, $\$ 8.50$; Lion, with separator, $\$ 11.00$.

Shovels. Round and square point, .75 and .85 .

Spades. .75 and .85 .

Stanchions. Prescott's, $\$ 1.40$; Parson's, $\$ 1.50$; Chain Hanging, $\$ 1.40$.

Sprinklers, Lawn. Fountain, $\$ 1.25$; Century, .75; 4 Arms, $\$ 3.00 ; 8$ Arms, $\$ 3.50$; Water Witch, .50.

Sprayers, Acme. These little sprayers have met with a large sale since their introduction. They are needed by every poultryman and farmer, and should be in every household. Great advantage is derived by the use of these sprayers in exterminating potatobugs, tobacco, corn, tomato and currant worms and all plant insects; also in killing lice in poultry houses. They are used extensively on horses, cattle and swine, and for spraying clothes, carpets, cigar wrappers, etc, in fact, wherever a sprayer is needed. These sprayers are light, strong, compact and well made. Each is tested with an automatic spray pump before it leaves the factory. Each, tin, .50; express paid, .70. 

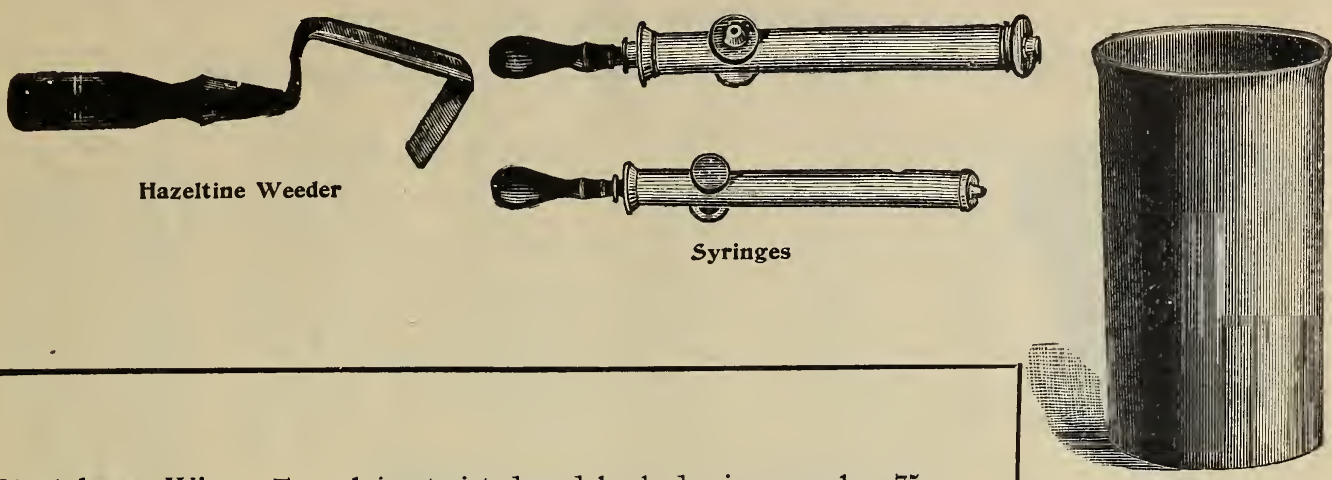

Fibre Vase

Stretchers, Wire. For plain, twisted and barbed wire; each, .75. Thermometers, Japanned Tin Case. 6 in., .30; 8 in., $.40 ; 10$ in., $.50 ; 12$ in., .90 .

Incubator. Cyphers', .60; Prairie State, .50, with stand, .75.

Brooder. Cyphers', 45 and 55 ; Spirit, .35; Wilder, .35.

Dairy, Floating. .25.

Tin Foil. Common, .15 per $1 \mathrm{~b}$.; Violet, .50 per $1 \mathrm{~b}$.

Torch. Asbestos, for caterpillars, .50.

Tomato Supports. Made of heavy galvanized wire, .20 each; $\$ 2.00$ per doz.

Tooth Picks. Per box, .10.

Tree Pruners. Waters', $6 \mathrm{ft} ., .75 ; 8 \mathrm{ft} ., .85 ; 10 \mathrm{ft} ., \$ 1.00 ; 12 \mathrm{ft}$., $\$ 1.15$; Rockdale, $2 \mathrm{ft}$. handles, $.75 ; 3 \mathrm{ft}$. handles, $\$ 1.00$.

Trowels. Cleve's Angle, 5 in., .20; 6 in., .25; 7 in., .30; American steel, .10; Extra Quality, .35 and .40 .

Twine. White Cotton, .25 per 1b. ; Jute, .15 per 1b. ; Hemp, .10 and .20 per ball; Binder, market price; Silkaline, for stringing similax and bouquet work, .25 per spool.

Vases. Fibre, for cut flowers, .20 to .75; Earthen, for cut flowers, .20 to .30 .

Water Pots. Heavy Galvanized.
4 qts......\$\$ .50
6 qts......... .55
8 qts......... .65
Heavy, painted green.
6 qts........ $\quad .75$
10 qts......\$ $\$ .75$
12 qts........ . .85
16 qts....... 1.25
10 qts....... 1.25
$12 \mathrm{qts} . \ldots \ldots \quad 1.50$

Parlor, 1 qt., .35; 2 qts., .45.

Weeders, Garden. Excelsior, .15; Lang's, .25 ; Noyes', .25 ; Haze1tine's, .25.

Wheelbarrows. Garden, No. 2, $\$ 2.90$; No. 4, $\$ 3.25$; No. $6, \$ 4.00$; Canal, steel wheel, $\$ 2.00$; wood wheel, $\$ 1.75$.

Weaners, Rice's Calf. No. 1 , for calves, . 30 ; No. 2,1 to 2 years, .50; No. 3, for full grown, .75 .

Wickets. For Garden Borders, wrought iron, painted green.

No. 1 D. $16 \times 25$ in. takes 100 Borders for $100 \mathrm{ft}$. ; $\$ 1.25$ per doz.; .12 each.

No. 1 C. $13 \times 20$ in. takes 130 Borders for $100 \mathrm{ft}$; .65 per doz. ; .06 each.

No. 1 B. $10 \times 15$ in. takes 180 Borders for $100 \mathrm{ft}$; .40 per doz.; .04 each.

No. 1 A. $8 \times 12$ in. takes 220 Borders for $100 \mathrm{ft}$; .25 per doz.; .03 each.

"Anchor" Flower Bed and Lawn Guard, 16 ins. high, per ft., .10.

Wine Presses. No. $1, \$ 4.50$; No. $2, \$ 5.00 ;$ No. $3, \$ 9.00$.

Wire, Barbed, Plain, Twisted and Ribbon. (Prices on application.) Florists', all sizes. (Prices on Application.)

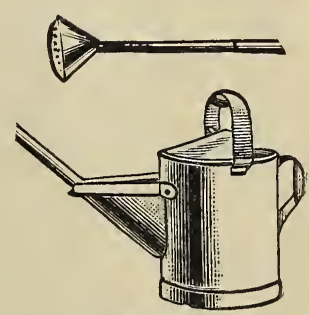

Water Pot

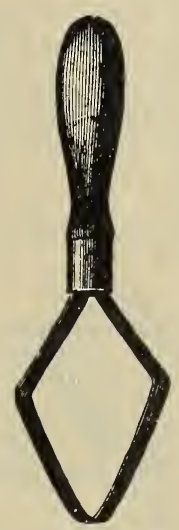

Noyes' Woeder

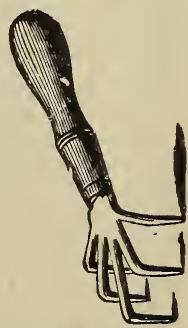

Excelsior Weeder

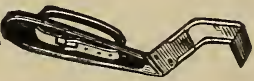

Lang's Weeder 


\section{STANDARD FLOWER POTS.}

Measurements from Inside to Inside. Width and Depth Fqual.

Special price on large quantities.

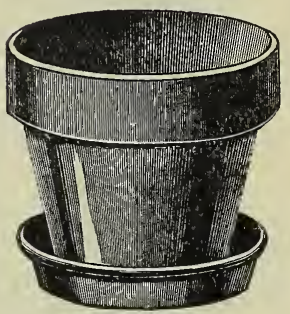

\begin{tabular}{|c|c|c|c|c|c|c|c|}
\hline Inch. & \multicolumn{2}{|c|}{ Each } & Doz. & Inch. $\quad$ Each & Doz. & \multicolumn{2}{|r|}{ Hund. } \\
\hline $21 / 4$ & $\ldots \$$ & $.01 \ldots$ & $\ldots \$ .65$ & $10 \ldots \ldots$ & $\$ 2.40$ & & 15.00 \\
\hline $2^{1}$ & & $.02 \ldots$ &.$\quad .85$ & $11 \ldots \ldots$ & .3 .00 & & 20.00 \\
\hline 3 & & $.02 \ldots \ldots$ & .1 .00 & $12 \ldots \ldots$ & . 4.20 . & & 30.00 \\
\hline $3^{1}$ & & $.03 \ldots$ & . 1.25 & $14 \ldots$ & $\ldots \ldots$ & each & .75 \\
\hline 4 & & .03 & 1.50 & 16. & 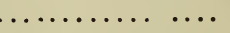 & & 1.35 \\
\hline 5 & & $\cdots$ & 2.50 & 18 & ...... & " & 2.00 \\
\hline 6 & & $\cdots$ & 4.00 & 20 . & . & “ & 3.00 \\
\hline 7 & & .08 & 6.00 & 22 . & & “ & 3.75 \\
\hline 8 & & .12 & $\cdot 8$. & $24 \ldots \ldots$ & - . . . . . . & " & 4.50 \\
\hline & & & & & & & \\
\hline
\end{tabular}

\section{FLOWER POT SAUCERS.}

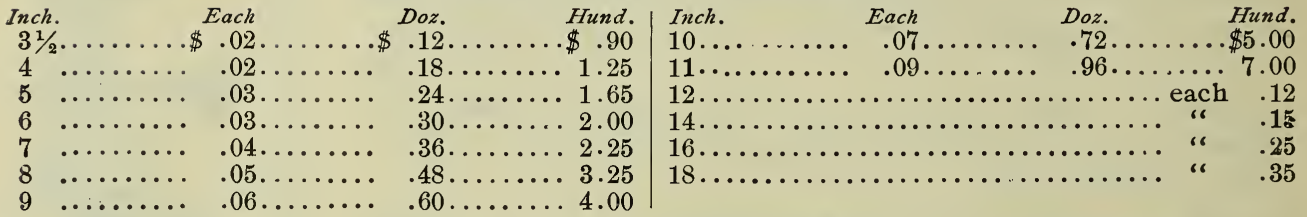

\section{BULB OR SEED PANS.}

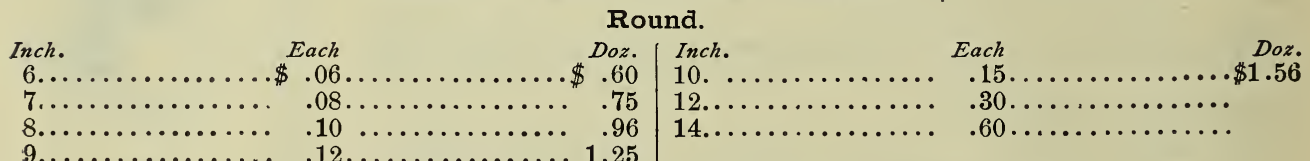

\section{WATER-PROOF FLOWER POT SAUCERS.}

They do not absorb moisture, and are indispensable when decorative plants are placed on the table, carpets, etc., thus preventing all injury by moisture.

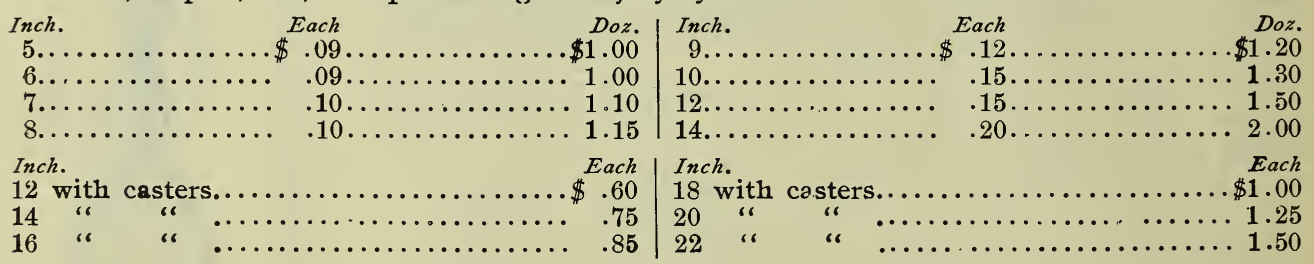

\section{FERN PANS AND SAUCERS.}

The pans are especially adapted for linings to porcelain and silver fern pans.

OUTSIDE MEASUREMENTS.

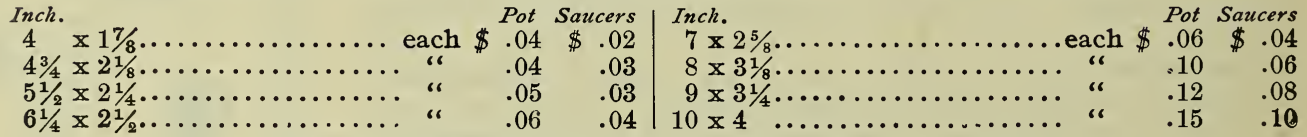

\section{NEPONSET PAPER FLOWER POTS.}

\begin{tabular}{|c|c|c|c|c|c|}
\hline$\cdots \cdots \cdots \cdots \cdots \cdots \cdots \cdots \cdots \cdots \cdots \cdots \cdots \cdots \cdots \cdots \cdots$ & 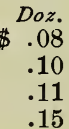 & $\begin{array}{l}\text { Hund. } \\
\$ .25 \\
.30 \\
.45 \\
.60\end{array}$ & 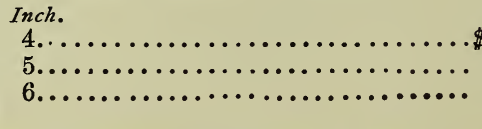 & $\begin{array}{r}\text { Doz. } \\
.20 \\
.30 \\
.40\end{array}$ & $\begin{array}{l}\text { Hund. } \\
\$ .80 \\
1.20 \\
1.65\end{array}$ \\
\hline
\end{tabular}

\section{LABELS, WOOD. For Plants, Trees, Etc.}

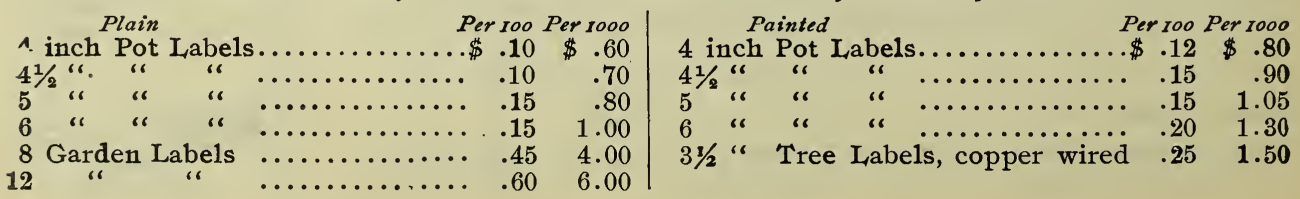




\section{GARDEN TRELLIS.}

Veranda. This is by far the most ornamental and substantial Trellis made, being especially adapted to outdoor use for high climbing shrubs and vines. Made of wood and rattan, and painted green.

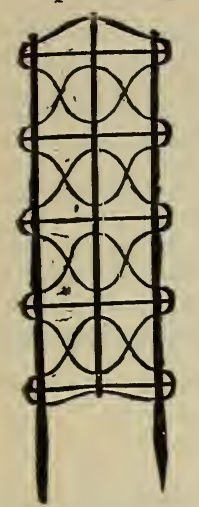

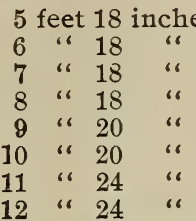

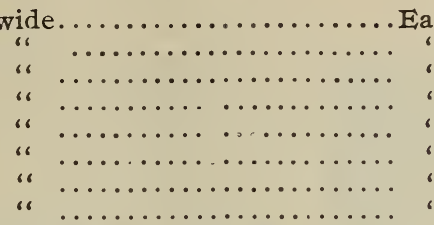

Each
"،
"
"
"

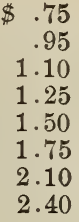

FAN TRELLIS, For Vines.
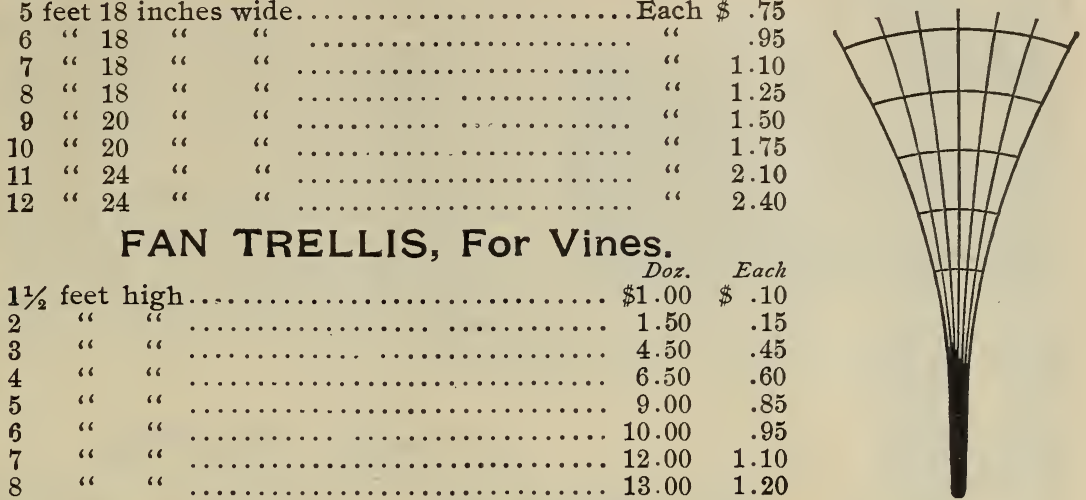

PLANT STAKES. Round, Tapering, Painted Green.

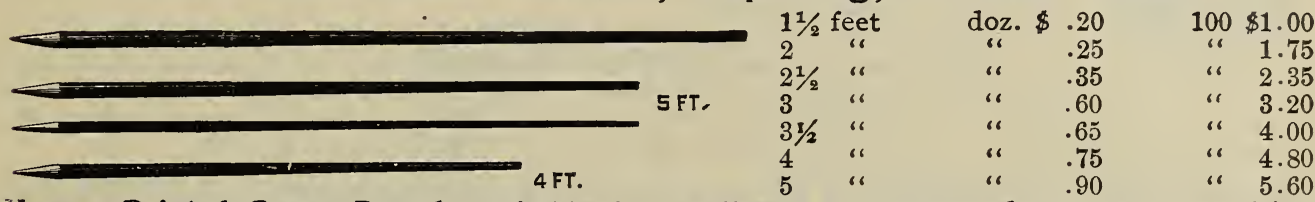

Heavy, Painted Oreen, Round. Suitable for Dahlias, Hollyhocks, and all plants requiring strong support.
3 feet long
doz. \$. . \%
\begin{tabular}{l|l|l}
100 & $\$ 4.85$ & 5 \\
" feet long & 6.50 & 6
\end{tabular}
doz. $\$ 1.25$
$100 \$ 8.15$
$\begin{array}{llll}4 & \text { " } & 1.10 & \\ \text { Square, Green Painted. Strong and durable. }\end{array}$

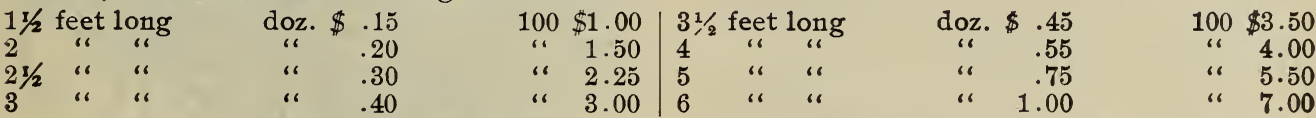

Cane Stakes. These are light, strong and durable. They vary in length from six to ten feet; can be cut to the desired length. 1 doz., $.20 ; 100, \$ 1.00$.

Unpainted Hardwood Stakes. Square, $2 \mathrm{ft} ., 100, .25 ; 3 \mathrm{ft} ., 100, .30$.

Wire Stakes. Made of galvanized wire. 3, 31/2, $4 \mathrm{ft}$. Price on application.

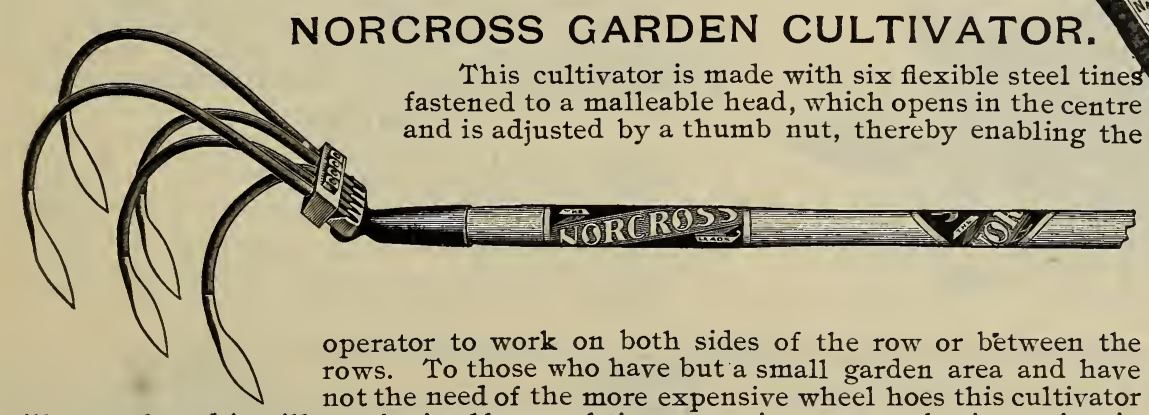
will appeal, and it will pay for itself several times over in a season by its saving in labor. Complete, with 5-ft. handle, $\$ 1.00$.

\section{IRON AGE LABEL AND ROW INDEX.}

By the use of this marker you are enabled to know what you plant, where you plant it and when you plant it. The labels are removable and may be filed for future reference.

It is made of galvanized iron and the label is protected by a sheet of mica. It will be found indispensable for private gardens, trial grounds, experimental plots, in greenhouses, parks, etc. Price, .20 each; per doz., $\$ 2.00$; per $100, \$ 15.00$. 


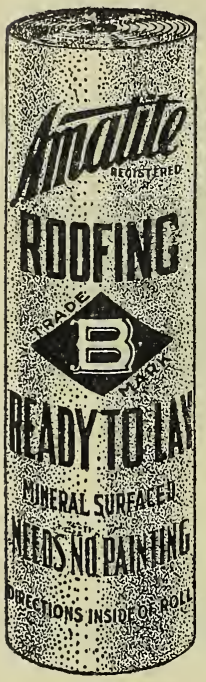

\section{AMATITE ROOFING.}

These are cemented together with straight-runs coal tar pitch. The wearing surface is supplied by covering the side to be exposed to the weather with a specially prepared bituminous compound, into which while hot is embedded a uniform and even layer of "Amatite," the new non-conductive stone surface. It is then passed between heavy rollers, making a smooth and compact sheet of most attractive appearance.

"Amatite" is water, wind and weather proof, and a fire retardent and requires no painting or repairing and is a decided improvement on any other ready roofing on the market. It requires no skilled mechanic to lay it; any man can do the work by following the instructions which come with each roll. It is put up in rolls 32 inches wide, containing 110 square feet, sufficient to cover 100 square feet of surface. Included in the roll are the nails and cement for laps. Price, per roll, $\$ 2.00$.

\section{LYTHOID ROOFING.}

Lythoid roofing does not run in hot weather. It does not pull and break in cold weather. It does not swell and wrinkle all over your roof and crack. It does stay where it is put.

Lythoid does not require painting for five years.

Lythoid can be easily applied by anyone; the only things required are a knife and a hammer. Rolls are 36 inches wide, containing 108 square feet of material, enough to cover one square (a square is 10 by $10 \mathrm{feet}$ ). Included in the roll are the tins, nails and cement. Price, 1-ply Lythoid roofing, per 108 square feet, $\$ 2.25$.

\section{COMBINED BARREL TRUCK, HAND CART AND LEAF RACK.}

When we consider the almost innumerable uses to which our Combined Truck and Hand Cart can be applied, its "handiness" and the immense amount of time and hard labor saved by its use, it is not a matter of surprise that it is steadily growing into popular favor.

The barrel is raised from the ground, carried to the place desired and instantly detached, all without handling. The weight being balanced over the axle, no lifting or down pressure is needed in transportation.
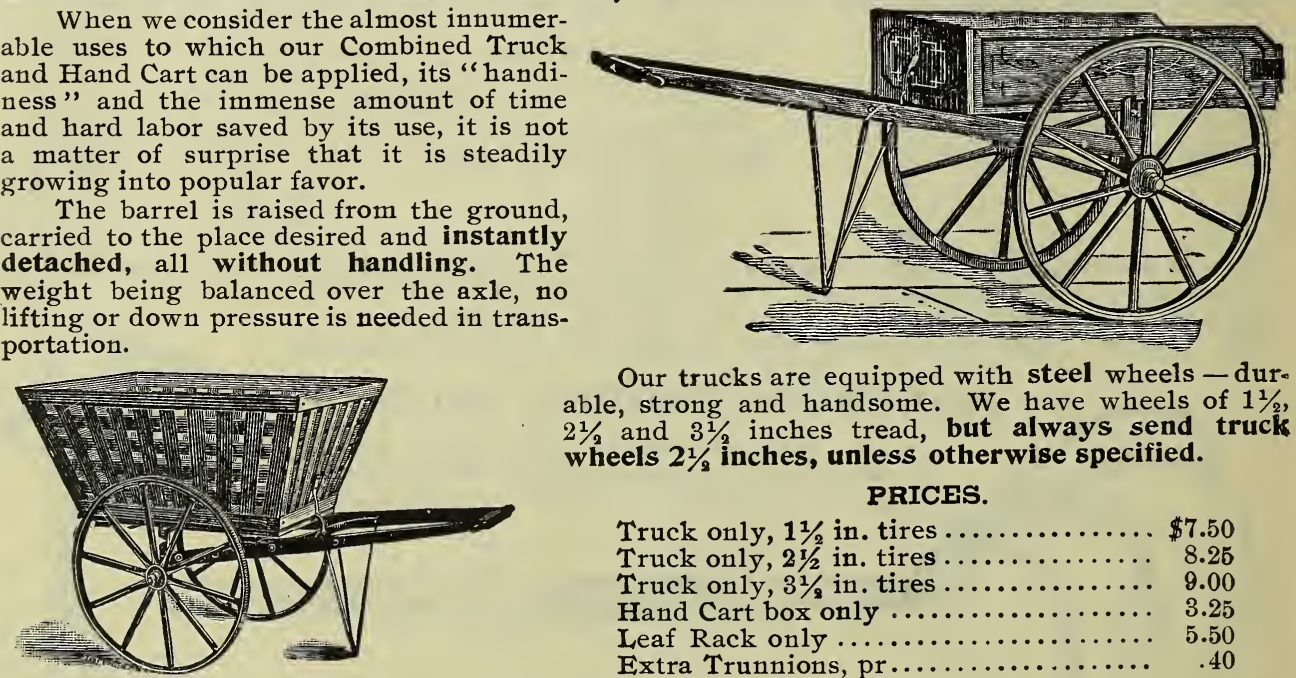

Our trucks are equipped with steel wheels - dur. able, strong and handsome. We have wheels of $1 \frac{1}{2}$, $2 \frac{1}{2}$ and $3 \frac{1}{2}$ inches tread, but always send truck wheels $2 \frac{1}{2}$ inches, unless otherwise specified.

\section{PRICES.}

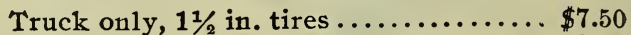

Truck only, $21 \% 2$ in. tires ........... 8.25

Truck only, $3 \frac{1}{2}$ in. tires ............. 9.00

Hand Cart box only .............. 3.25

Leaf Rack only ................. 5.50

Extra Trunnions, pr............... $\quad .40$

\section{"ANCHOR" FLOWER BED AND LAWN GUARDS.}

These guards fill a long-felt want, and are far superior to the makeshifts generally used. They are entirely constructed of Nos. 8 and 9 Galvanized Steel Wire. The Horizontal Wires being absolutely locked to the Upright Wires by our patented Anchor Clamp make the joints " rivet tight." They cannot slip. Anyone can put the Guard in place, and when in place it is a Guard. Price, 16 in. high, .10 per foot.

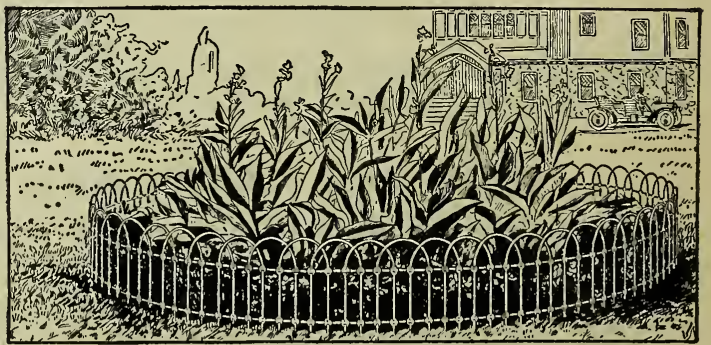




\section{THE NEW QUAKER CITY AND GARDEN CITY LAWN MOWERS.}

These Mowers are of the internal gear construction, the driving gear being encased within the wheel and positively protected from dust and dirt.

The adjustments are serviceable, simple and exact throughout. The ratchet has a self-adjusting pawl, without springs, but is a positire clutch upon pushing the mower forward. The handle braces are adjustable to suit heights of different persons using the mower. They are built for hard wear and are guaranteed in all respects.

The bed-knife is made of the best quality of steel, but flexible and adjusted to conveniently touch the revolv-

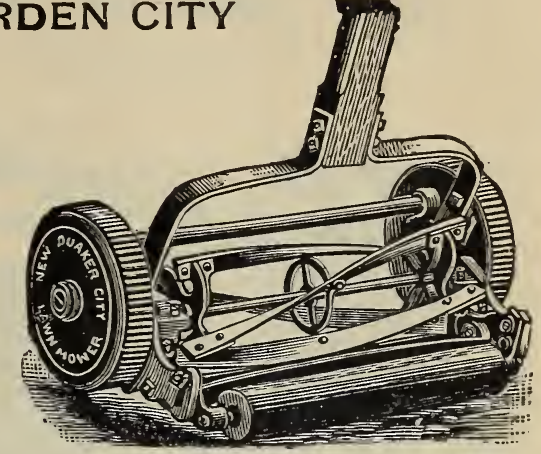
ing cutters, making the mower positively self-sharpening.

Garden City, 12-in. Solid Knife.....\$\$6.00

"

New Quaker City, 12-in. Open Knife...\$6.00

" " " " 14 -in. " " "

" " " "

" 18-in. " "

" " " 18-in.

7.50

\section{COLDWELL'S IMPROVED HORSE LAWN MOWER.}

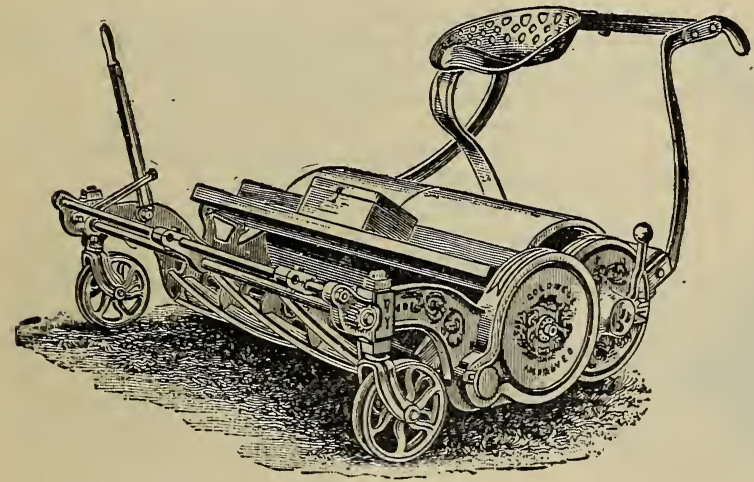

This well-known standard Mower has side-draft attachment, to enable the horse to walk on the cut grass only, and caster rollers, which will not mark the lawn. Evenness of cut is assured by an adjustment which raises or lowers the two sides at the same time by means of a simple lever movement; the same lever serves the purpose of raising the knives from the ground when driving over gravel walks or roads. The Mowers are fitted up with steel shafting and

composition split bushings, and great care is taken to have the workmanship perfect.

\section{PALMER'S HOT BED MATS.}

These are made expressly for winter covering of hot beds and cold frames. They are indestructible, cheap and warm, and will not harbor mice or vermin.

Have now been in practical use for years, costing less than the old-fashioned straw mats and entirely take their place.

Size $76 \times 76$, burlap and duck.........each, $\$ 1.45$

" $76 \times 76$, plain burlap........... " 1.15

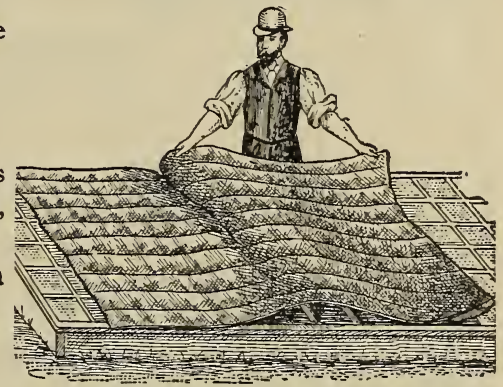

\section{THE STEVENS HAND FERTILIZER SOWER.}

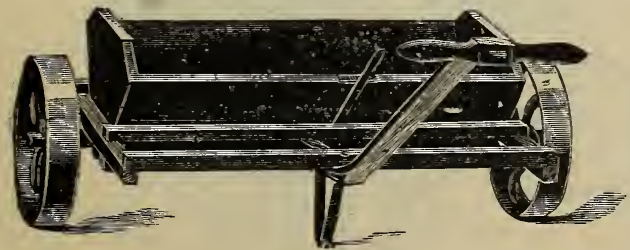

Does the work perfectly, sowing all kinds of lawn dressing and other commercial fertilizers, wood ashes, lime, etc., in larşe or very small quantities. It can also be successfully used for fertilizing strawberry beds, and other garden and field work; is excellent for sifting wood or coal ashes, sawdust or dry sand on icy walks; will also sow damp sand by remoring two blades.

The hopper is 34 inches long and holds one and one-half bushels. Weight of machine, 83 pounds. It is well made and nicely painted. Price, $\$ 12.00$ 


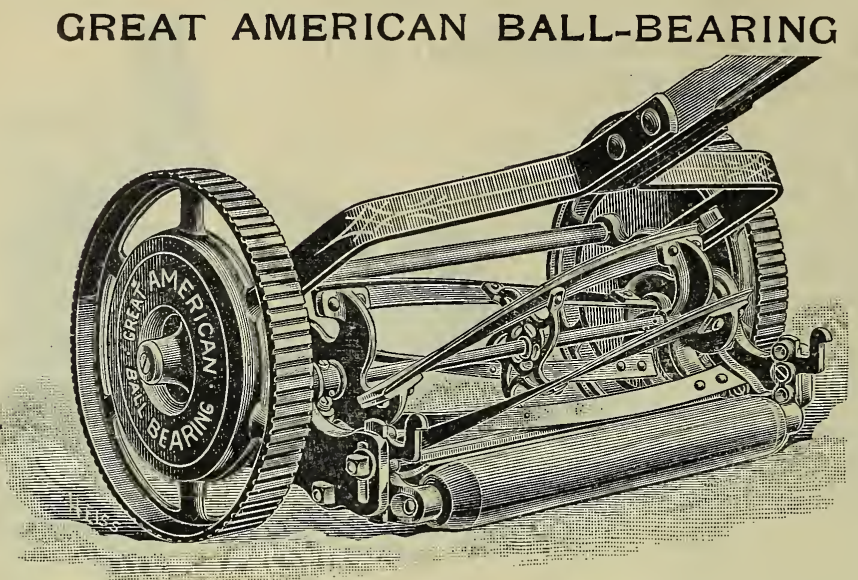

\section{LAWN MOWER.}

No Bicycle was ever built possessed of an adjustment of greater nicety than the ball bearings of this superior Lawn Mower. The highest grade steel balls of unvarying exactness are used in absolutely dust-proof steel covered cups, and the balls rest in an improved ball retainer and separator.

This machine is equipped with a self-sharpening upturned dead knife of solid cast steel, which can be regulated to cut from $3 / 8$ to $13 / 8$ inch from the ground.

It is finished in aluminum and gold, and is a very attractive machine, and we guarantee it to do superior work and to be possessed of great durability. $15 \mathrm{inch}, \$ 9.00 ; 17 \mathrm{inch}, \$ 10.00 ; 19 \mathrm{inch}, \$ 11.00 ; 21 \mathrm{inch}, \$ 12.00$.

\section{THE DUNHAM LAWN ROLLER.}

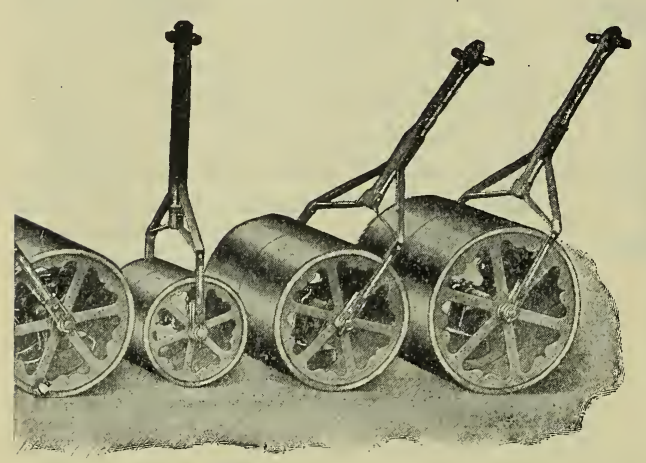

This roller is turned perfectly smooth on the outer surface and the outer edges are bevelled to avoid cutting up the lawn. The áxles are steel and the handles are rigid and durable.

The lawn roller is a tool that has come to the front and its use is now considered the most essential feature of a good lawn.

In the spring, after the freezing and thawing season, the ground becomes uneven and porous, recting from the grass roots. If allowed to settle of its own accord the lawn is left rough and the grass liable to die off in the high spots. If pressed back evenly and firmly with a lawn roller the chances for a new velvety lawn are much more favorable. Again rolling during the summer season after rains will be found very helpful and tend to make a much thicker lawn.

PRICES.

$\begin{array}{lccccc} & \text { Diameter } & \text { Length } & \text { Sections } & \text { Weight } & \text { Price } \\ \text { No. } & 15 \text { in. } & 24 \text { in. } & 3 & 180 \text { 1bs. } & \$ 9.00 \\ \text { No. } 8 & 20 \text { " } & 24 \text { “ } & 2 & 245 \text { “ } & 12.00 \\ \text { No. } 9 & 20 \text { " } & 24 \text { “ } & 3 & 275 \text { " } & 13.50 \\ \text { No. } 17 & 24 \text { " } & 24 \text { “ } & 2 & 290 \text { “ } & 14.50\end{array}$

\section{BRAUN GRASS CATCHER.}

This catcher has a galvanized bottom that will not sag or drag on the ground when filled. The sides are of canvas, and the catcher being supported on truss rods and not attached to handle it has great strength and firmness. It can be attached or detached in a moment and may be emptied by simply dumping it forward without detaching. This catcher will fit any of the hand mowers described in our catalogue and also the well known Pennsylvania and Continental lawn mowers.

\section{PRICES.}

15 and 16 in., each ............. $\$ 1.70$

17 and 18 in., " $\ldots \ldots \ldots \ldots \ldots \ldots \ldots \ldots . .1 .80$

19 in., 18 in.,

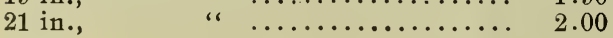

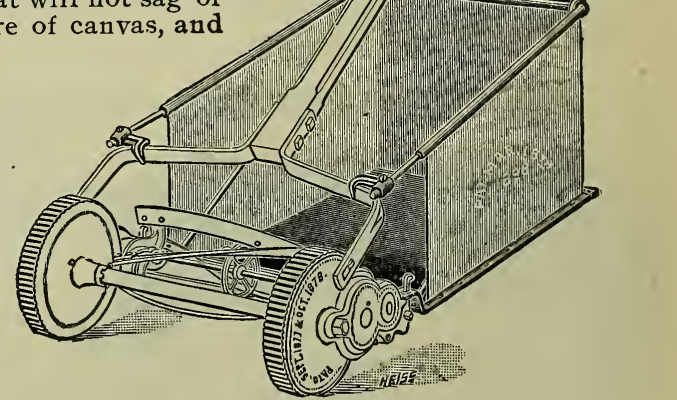




\section{NO. 6 IRON AGE COMBINED DOUBLE WHEEL HOE,}

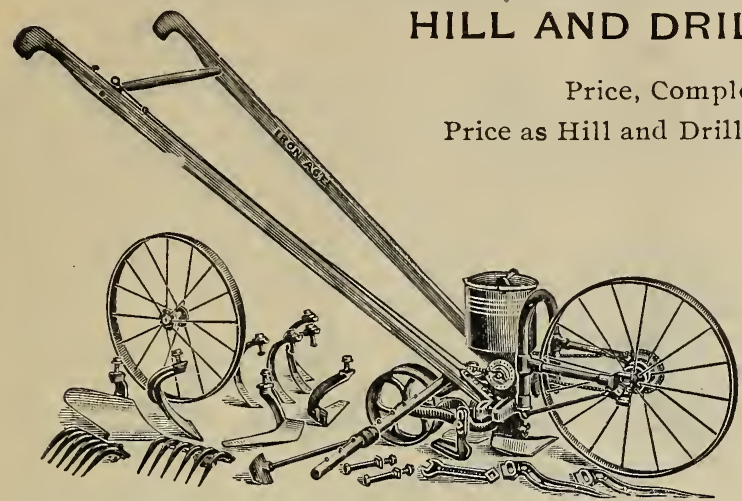

This tool is without question the most practical and complete combined yarden implement ever offered the publicthe ease and simplicity of adjustment, the lightness combined with great strength, the accuracy by which it hills or drills the seed, and the small amount of power required to operate it are the important features. In each form, whether a Seed Drill, a Double Wheel Hoe or a Single Wheel Hoe, it is equal to any tool or tools made especially for the one purpose. The Opening Plow is clog-proof, all trash which may come in contact with it is ridden down. By a thumb screw it can be instantly adjusted in depth. The Marker is pivoted at the rear of the hopper and can be thrown from side to side by the foot, and the adjustment of the drag be made by inches.

\section{NO. 4 IRON AGE COMBINED DOUBLE WHEEL HOE AND SEED DRILL.}

Price, Complete, $\$ 11.00$.

Price as Drill Seeder only, $\$ 8.00$.

Combined in this tool are a Seed Drill, a Double Wheel Hoe and a single Wheel Hoe. In each form, these tools are equal to any tool or tools made especially for the one purpose.

As a Seed Drill this tool sows in drills with perfect accuracy all seeds varying in size from celery to corn. Easily and quickly ađ̛justed in every particular.

The change from a Seed Drill to a Wheel Hoe is made by simply detaching the Seed Hopper with the frame, covers, wheel, etc., loosening two bolts does it, and applying the cultivating tools. The wheel is made of steel, 16 inches high ; the frame of pipe, coupled to malleable castings. The tool is, therefore, very light as well as strong-runs easy.

\section{NO. 8 IRON AGE HILL AND DRILL SEEDER.}

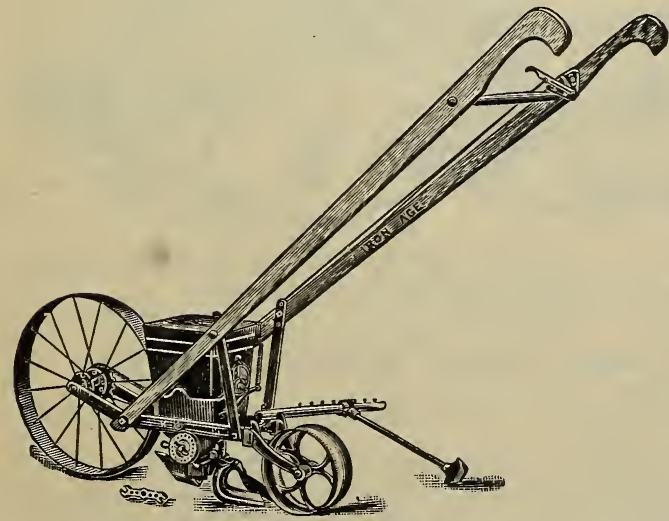

Price, $\$ 11.00$.

This Seeder is simple, light, strong and capacious. The wheel is fifteen inches high and has a two-inch thread. Being made of steel it is very light, the Hopper is low, therefore the delivery of the seed is close to the ground. Its capacity is four quarts.

The agitator is a revolving brush which makes a sure feed, and sows all seed accu. rately and without injury. The Opening Plow is positively clog-proof. Distance of spacing the seed can be instantly changed. It will drop in hills at $4,8,12$ or 24 inches apart, or sow in rows.

From a Hill Dropper to a Row Drill, or vice versa. By simply hooking out a small lever, which operates the seed cut off, you at once have a drill seeder, and by reversing the operation you again have the tool ready for spacing the seed for hills. 


\section{NO. 1 IRON AGE DOUBLE WHEEL HOE.}

Price, Complete, $\$ 7.00$.

Price, No. 3, rlain, with side hoes only, $\$ 4.25$.

One great advantage which this Double Wheel Hoe possesses is that it can be made into a practical Single Wheel Hoe in a moment's time. The wheels are 16 inches high, enabling the wheel hoe to run easy and without yielding to the inequalities of the soil, as a low wheel will do. The Frame being made of pipe coupled to malleable castings, gives great strength, together with lightness. We wish to strongly emphasize the really extraordinary ease with which the "Iron Age" Wheel Hoe is operated, the lightness and construction of the tool being such that every ounce of effort goes direct to the work accomplished.

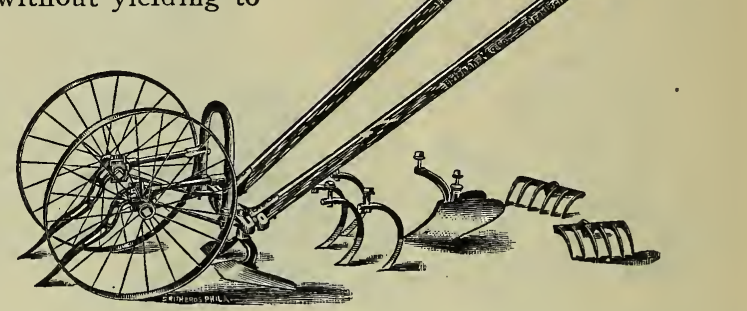

\section{NO. 15 IRON AGE COMBINED SINGLE WHEEL HOE, HILL AND DRILL SEEDER.}

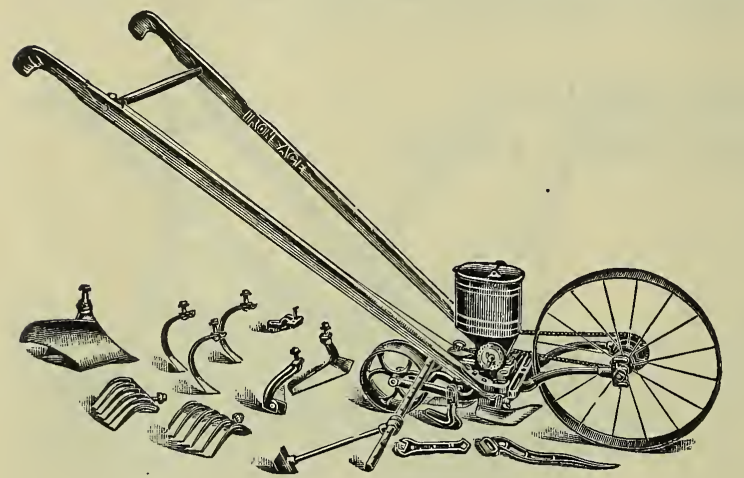

Price, Complete, $\$ 11.00$.

Price, as Seed Drill, $\$ 8.50$.

Combined in this tool are the best Hill and Drill Seeder, and Single Wheel Hoe ever offered the public. In combining these tools, not a single advantage of a separate Single Wheel Hoe or Hill and Drill Seeder is lost. As each they are in themselves, complete. It places the seed in hills or drills, it plows, it rakes, it opens furrows, it covers, it hills, it hoes, it cultivates. The wheel is made of steel, 16 inches high ; the frame of pipe, coupled to malleable castings; therefore light (runs easy), strong and durable.

\section{NO. 17 IRON AGE COMBINED SINGLE WHEEL HOE AND SEED DRILL.}

Price, Complete, $\$ 10.00$.

Price, as Seed Dril1, $\$ 7.50$.

Likewise, in our Single Combined Tools for the accommodation of those who have no preference for a Seed Drill to drop in hills as well as sow in rows, we offer a tool very similar to our No. 15 without the Hill Dropping Device, which we term our No. 17 "Iron Age" Combined Single Wheel Hoe and Drill Seeder, the price of which is one dollar less than No. 15.

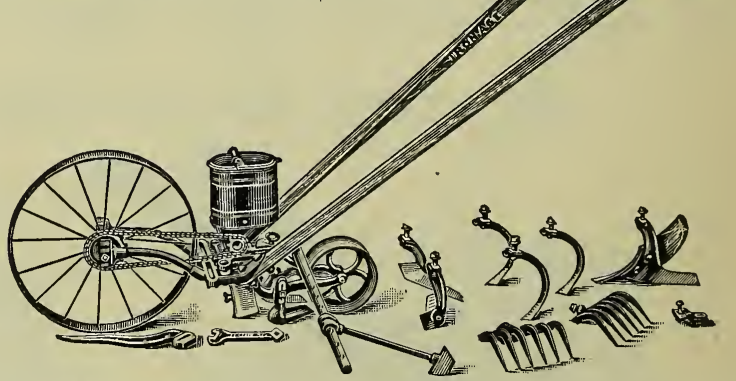

What we have said above relative to the Wheel Hoe form of our No. 15 Combined Tool applies with equal force to our No. 17 Combined Tool, for as Wheel Hoes they are identical.

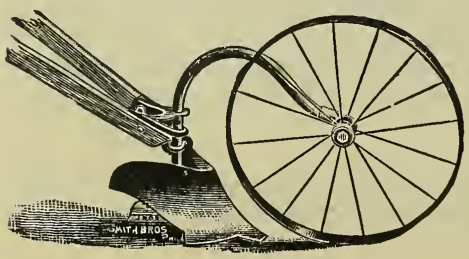

THE IRON AGE WHEEL PLOW.

Price, $\$ 2.50$.

To the owners of small gardens this tool is most useful. It will plow from three to four inches deep and throw a furrow four to six inches wide. Witl it the furrows for manure or seed can be opened or covered. It is very light and can be adjusted in depth, and we think we are right in calling it a "Little Beauty." 


\section{NO. 20 IRON AGE SINGLE WHEEL HOE.} Price, $\$ 6.00$.

The No. 20 "Iron Age " Single Wheel Hoe is the wheel hoe form of both the Nos. 15 and 17 combined Single Wheel Hoes and Seed Drills. Although being designed with a view of being able at any time in the future to add a seed Drill attachment, it is the most complete Single Wheel Hoe ever offered. The wheel is 16 inches high, and has a broad-faced tire, $1 \frac{3 / 4}{4}$ in. wide. The Frame is made of pipe, coupled to a malleable casting to which is attached the working tools and handles. The No. 6 "Iron Age" Hill and Drill Seeder attachment may be applied to this implement and when attached, the tool is identical with the No. 15 combined tool on preceding page. Price of attacliment, $\$ 4.50$. The No. 17 Drill Seeder Attachment may also be applied, which makes the tool the best combined Single Wheel Hoe and Drill Seeder on the Market. Price of attachment, $\$ 3.50$.

\section{THE NO. 12 IRON AGE WHEEL PLOW AND CULTIVATOR.}

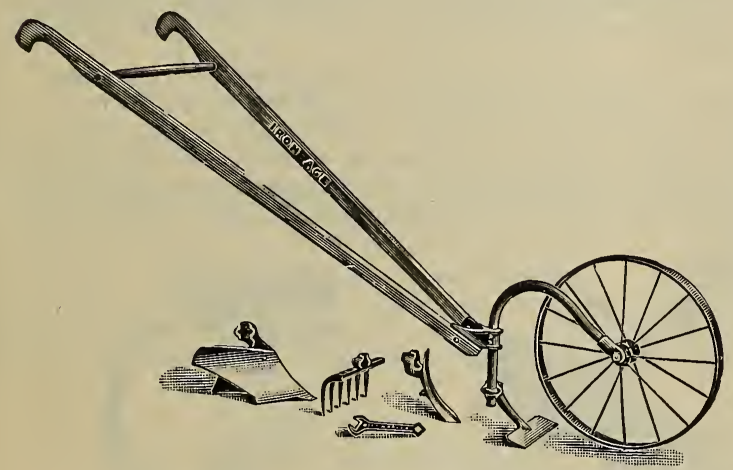

Price, $\$ 3.50$.

The simple means of detaching or applying the tools practically makes the implement ever ready for the purpose intended, therefore this tool is emphatically a friend of the laborer and mechanic who can afford only to invest a small amount of money in a garden tool, but whose few moments in the garden must be devoted to "straightahead" work.

The Wheel Plow and Cultivator is not only useful in cultivating vegetables, but also hoeing weeds out of paths, stirring the earth in the poultry yards, and a large number of other purposes which will suggest themselves to the operator.

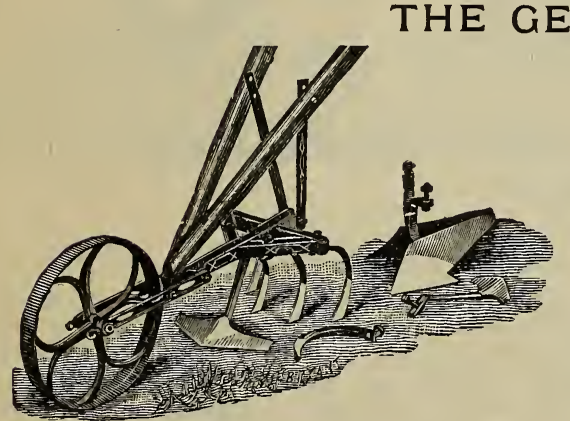

Price, Complete, $\$ 5.00$.

Price, Five Teeth only, \$3.75.

There can be no greater proof of the popularity of a tool than the continued demand for it. Among the many "Gem" Hoes we have sold we are not aware of a single instance in which they have failed to give satisfaction. It has a set of Adjustable Steel Teeth, two Push Hoes, and two small Plows. It is not a toy; neither is it a tool made of light gray castings, calling for constant repair, the "Gem" being largely made up of steel and malleable iron.

\section{THE NEW MODEL SEED DRILL.}

\section{Price, $₫ S .00$.}

In reference to the "New Model" Drill, we do not think it necessary to enter into a discussion about the necessity for and economy in the use of Seed Drills. Suffice it to say that the "New Model" is the result of careful experimenting in the field and factory, in close comparison with leading drills, and, being constructed with the view of avoiding all radical defects of said drills, built in a workmanlike manner, of best material, and in neat style and finish, we venture to assert it will be found to be the best seed drill in use and indeed a snodel in every respect. 


\section{ATTACHMENTS TO IRON AGE WHEEL HOES.}

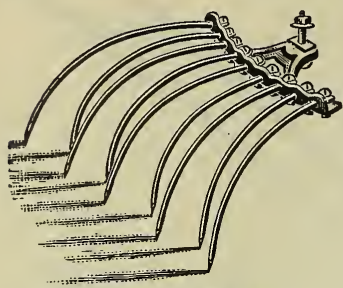

Fig. 84. Price 80c.

Fig. 81. Weeder Attachment. Very often it is found that the crust of soil is so firm the side hoes will not break it sufficiently to destroy the young weeds just germinating. This attachment leaves the ground perfectly level, with a mulch of fine soil on the surface that makes an admirable protection in time of drought. By changing to opposite sides they can be used between rows, while, if necessary, the width of cut can be reduced by removal of one or more teeth.

Fig. 84. Weeder Attachment for Single Wheel Hoes. By the application of this to the rear of the Single Wheel Hoe the same admirable work is accomplished, as by the similar attachment to the Double Wheel Hoe. The Weeder can be reduced in width to pass through narrow rows by removal of a portion of the teeth.

Landside Plow. Fig. 82 plainly shows the Landside Plow following in line with the single wheel, which converts the tool into a perfect Wheel Plow. This attachment can be used with two wheels, but is much more manageable with but one, as shown in cut. It is easily attached, plows deep, throws a strong furrow, and runs remarkably steady.

Double Mouldboard Plow. This may be applied to any and all of our wheel hoes and combined tools. Has adjustable wings to suit opening furrows of various widths. For narrow work the wings can be removed altogether. Price, $\$ 1.40$.

Single Tooth Attachment. When using the "Iron Age"

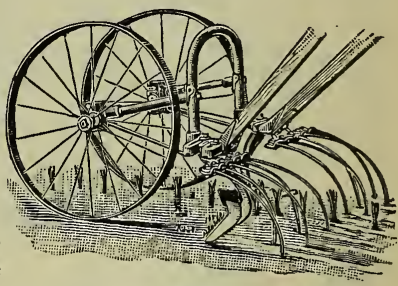

Fig. 81

Double Weeder Attachment Price per pair, $\$ 1.10$ Double Wheel Hoe as a Single Wheel Hoe, as a Cultivator, a wider space is left between the two inside teeth than there is between the other teeth. This is because as a Double Wheel Hoe the crops cultivated must pass between the two inside teeth, therefore, to thoroughly cultivate all the ground, while working the tool as a Single Wheel Hoe, it is necessary to add an extra tooth, as shown in Fig. 112.

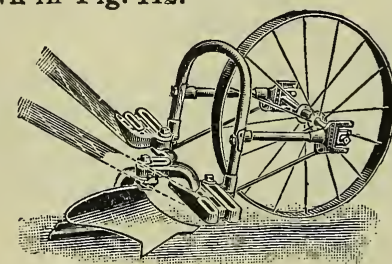

Fig. 82. Price 90c. The Landside Plow Attachment

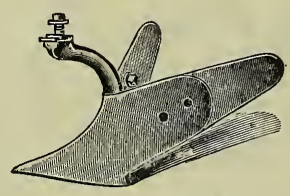

Fig. 170. Price \$1.40. Double Mold=board Plow Attachment.

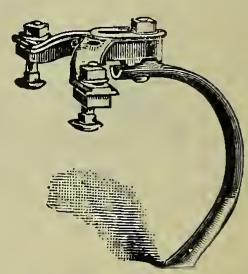

Fig. 112. Price 60c.

\section{NO. 25 IRON AGE FERTILIZER DISTRIBUTOR ATTACHMENT.}

Price, $\$ 4.50$.

Price, as Single Wheel Distributor, $\$ 8.00$.

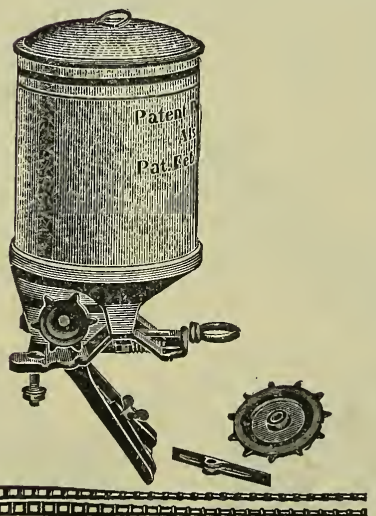

Fig. 184.

With the increasing sale and use of commercial fertilizers there has been a growing demand for an inexpensive garden implement for the application of same, both in furrows and for side dressing. The fact that commercial fertilizers are easier and more pleasant to handle than barnyard manures needs no explanation to those who have used both. They will also be found more effective if fertilizers of proper analysis are used.

With the "IRON AGE" Fertilizer Distributor fertilizer may be sown across the bottom of the furrow or. on either side, so it will not come in contact with the seed and possibly injure it; or the tool may be used for side dressing the growing crops. Side dressing often forces a crop to mature earlier, becoming more tender and salable. The tool is light in weight and strongly built.

The feed consists of a revolving wheel of such design as to force the fertilizer out. The castings inside of the hopper, coming in contact with the fertilizer, are galvanized to prevent rusting.

The cliain which drives the agitator is made of stee1 - very strong and durable. The fertilizer hopper is attached to the frame in the same way as our "IRON AGE" Seed Drills attachments, and its capacity is over 4 quarts.

This attachment may be applied to such "IRON AGE" hand No. 25 "Iron Age" Fertilizer Distrib= tools as may be purchased in the future, and also to Nos. 1,3 ,
utor Attachment, Price $\$ 4.50$. 


\title{
THE NO. 6 IRON AGE HORSE HOE AND CULTIVATOR.
}

Price, as in Cut, $\$ 6.25$.

Add for Lever Whee1, .50.

Add for Hilling Attachment only, \$1.60.

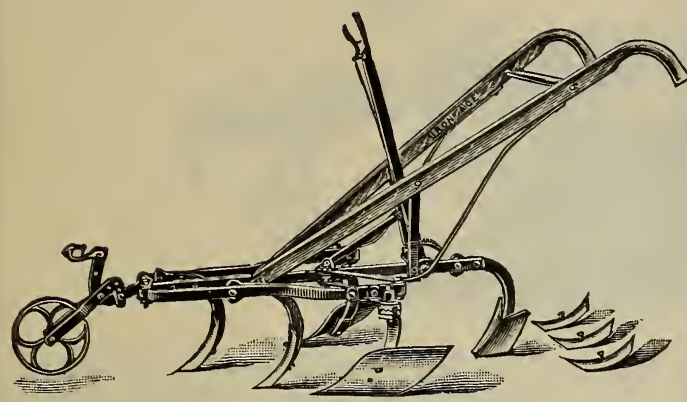

The No. 6 "Iron Age" Horse Hoe and Cultivator is truly a 20 th Century tool.

The Frame of this tool is high and long, therefore it runs steady and with excellent clearance of trash. The Horse Hoe standards carry the cultivator teeth, instead of using an additional pair of cultivator standards.

The Lever Expander has stood the test for several years with but little change, and we consider it, with its pair of double expander bars, the best of its kind for strength, sin1. plicity and rigidity. Is made entirely of steel and malleable castings, of good length, and placed in a convenient position for the operator. By the use of this Lever Expander the tool, as a cultivator, can be instantly changed while in motion from the extreme width of 30 inches to 14 inches as its narrowest. Or, the castings of the Hoe Standards of No. 6 can be placed on the inside of the frame, and it can then be used as a cultivator as narrow as 11 inches.

The Hilling Attachment shown in the cut is applied by removing four standards and placing the standard of the hiller on the middle bar and attaching the short standards of the blades to the side bars. It is used where higher ridging is desired than can be accomplished by the regular Horse Hoe blades.

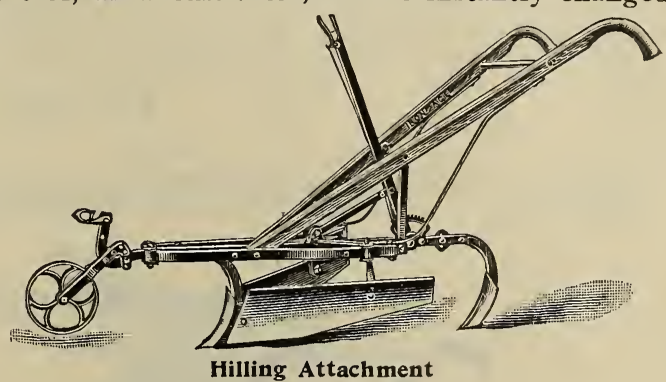

\section{NEW ENGLAND CULTIVATOR AND HORSE HOE.}

This is one of the most durable implements of its class on the market. The frames, shanks and lever are made from best quality spring steel; it has reversible steel points and oil-tempered adjustable steel wings. The machine can be changed instantly from a cultivator to a Horse Hoe by simply removing three thumb nuts, lowering the wings, and turning the end teeth on top of the frame. By this arrangement all risk of mislaid parts is avoided.

\section{IRON AGE COMBINED HARROW AND CULTIVATOR.}

\author{
Steel Diamond Teeth.
}

Price, Complete as in Cut, $\$ 5.80$.

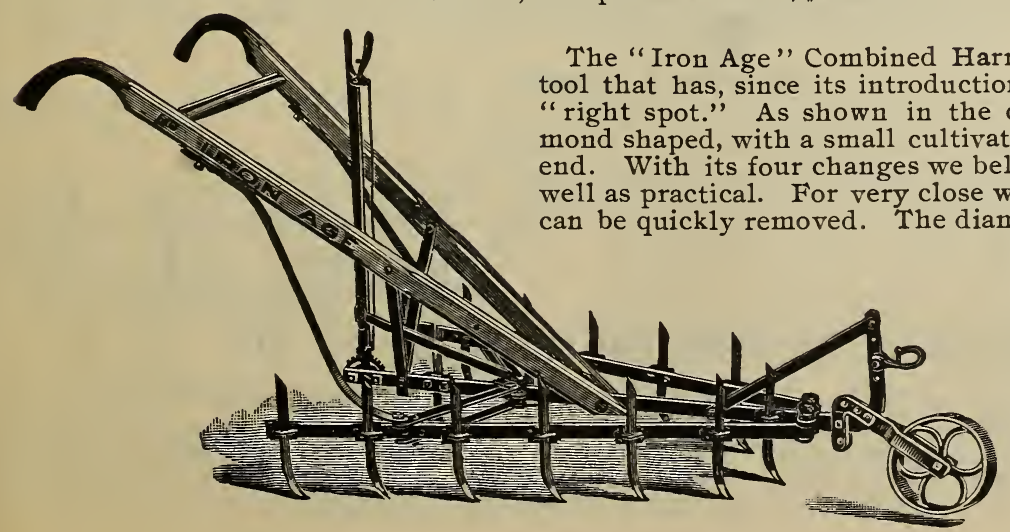

The "Iron Age" Combined Harrow and Cultivator is a tool that has, since its introduction, seemed to go to the As shown in the cut, the teeth are diacultivator tooth forged on one With its four changes we believe it to be unique as well as practical. For very close work, every other tooth ond pointed teeth are reversible and can be a d justed as spike tooth, smoothing or common cultivator. In common with all good things, this tool has numerous inferior imitations, but for solid quality, design or finish, is not approached by them. 


\section{VERMONTER STEEL MOULDBOARD PLOW.}

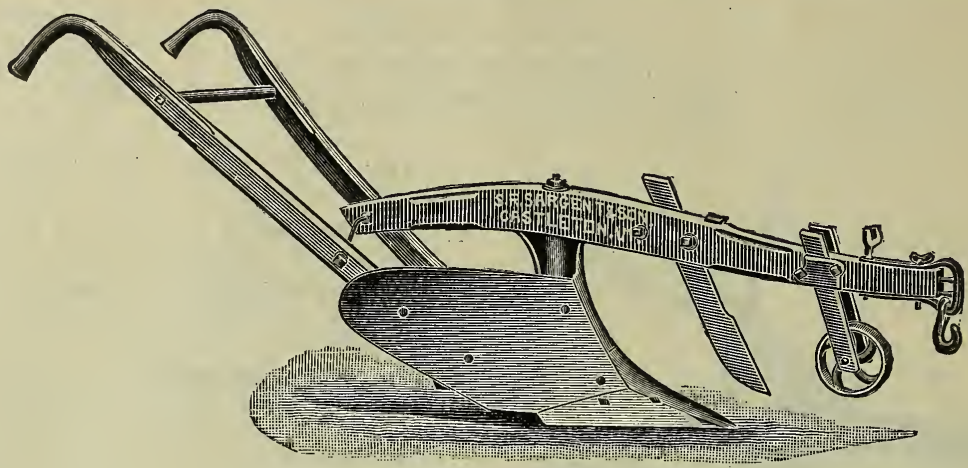

These steel mouldboard plows are made in two sizes, are warranted to scour in any soil and to stand in hard, rocky ground or among roots. They are a capital plow for breaking or plowing bog meadows, old pastures, etc. We can furnish for this plow a steel edged point for use in plowing wild grass, roots, etc. It cuts under as wide as the plow turns. Furnished with jointe: or straight cutter, as desired. Guaranteed to suit or no sale.

Prices and Capacity.

No.

8 Light 2-Horse, 4 to 8 .inches deep, 10 to 12 inches wide............ $\$ 10.00$

Cutter

9 Medium 2 " 5 to 9 " " 12 to 14 " " $\ldots \ldots \ldots \ldots \ldots \ldots \ldots \ldots \ldots$ 11.00

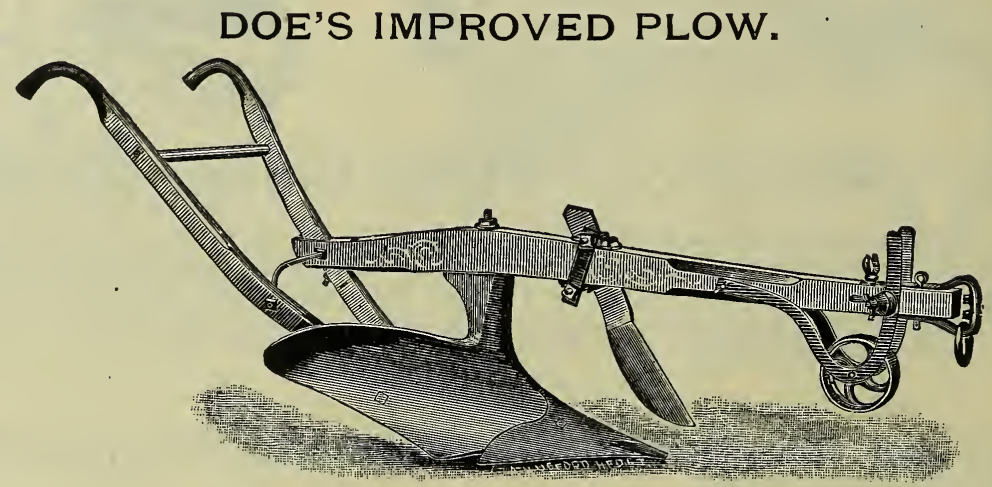

This plow is deservedly popular; owing to the position of the landside with the convex mouldboard, it turns a diamond shaped furrow, laying it very flat, covering up all grass, weeds, etc., without the use of a jointer. It is made of the best plow iron, in five sizes, suitable for one, two or three horses.

Prices and Capacity.

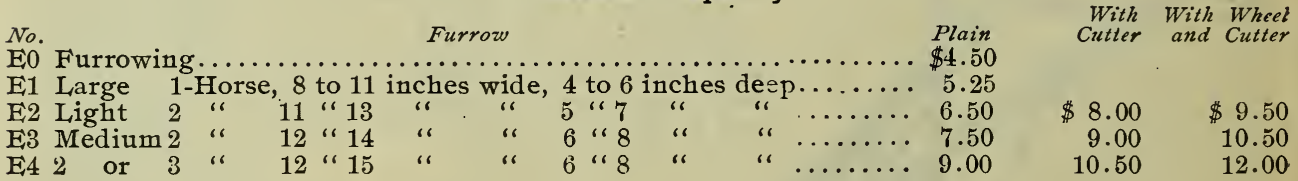

\section{SYRACUSE REVERSIBLE SULKY PLOW.}

This is the lightest draft sulky plow on the market. Will plow on sidehill or level ground and leave no dead furrows. Throwing the plow in and out of the ground is done by the team while the operator has control of the width of the furrow with his feet, leaving both hands free to handle the team. The wheels always stand perpendicular and the plows level. Cuts 3 to 9 inches deep and 11 to 16 inches. wide; weighs $556 \mathrm{lbs}$. Price on application. 


\section{DIAMOND SWIVEL PLOWS.}

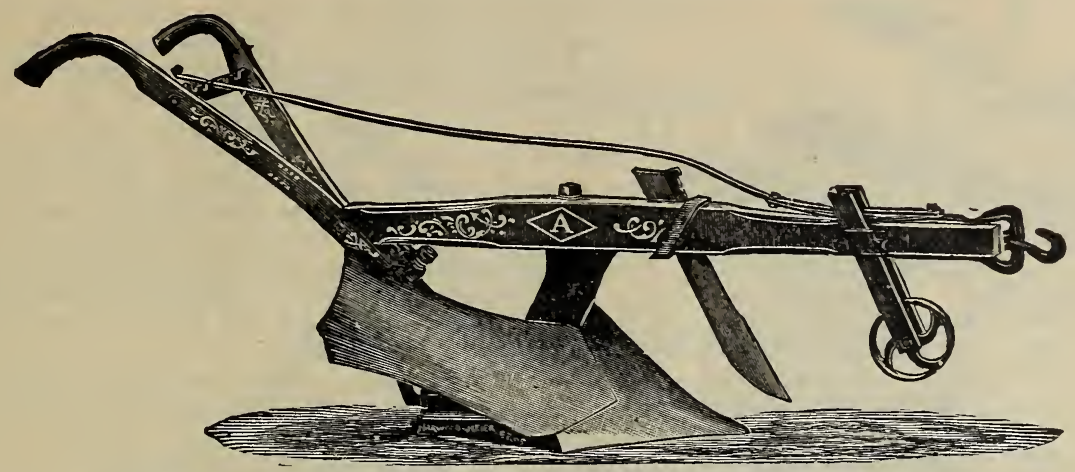

These plows are well and favorably known in New England and are strongly made of the best material obtainable. The mouldboards are steel and points are of chilled iron. The draft is light and they have the simplest and best Automatic foot latch used on any swivel plow. They are made in three sizes as follows:

No.

Furrow.

Weight.

Price.

A. Medium 2-Horse, 5 to 7 inches deep, 11 to 14 inches wide, $1301 \mathrm{bs} . \ldots \ldots \ldots \ldots \ldots \ldots 13.00$

B. Light 2 " 4 " 6 " 6 " 8 " 10 " 10,126 " $\ldots \ldots \ldots \ldots \ldots \ldots \ldots 12.00$

\begin{tabular}{|c|}
\hline Light \\
\hline
\end{tabular}

\section{DOUBLE MOULDBOARD PLOWS.}

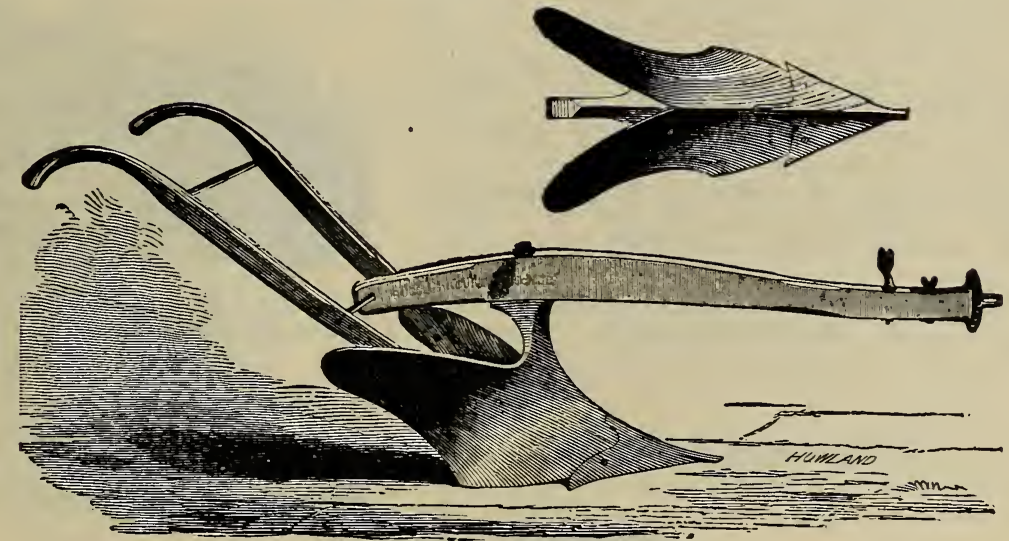

Our Double Mouldboard Plow is a one-horse plow used for making drills to plant potatoes, corn, etc. It is often used for plowing between rows, and throws the earth both ways to the plant, thus doing the work of two plows; many farmers use it for digging potatoes. It is a convenient plow for many kinds of work, ditching, etc., and should be kept on all farms.

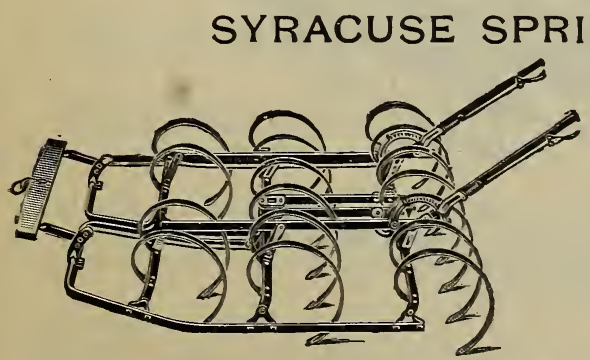

NG TOOTH HARROWS

Frame bars of angle steel thoroughly protected by steel shoes. Frame bars raised at the rear inner ends, as shown in cut, giving free outlet to trash. Frame with small opening at front, absolutely preventing all loading at this point, so common in other makes. Tooth bars of channel steel journaled in malleable brackets above the frame, which give the teeth high support and great range of adjustment for depth of cultivation and clearance. Springs of high carbonized steel without bolt holes, held in place by malleable holders, allowing separate adjustment when worn. Teeth instantly adjusted by levers to meet requirements of different soils. Central and direct draft without side motion, causing the ground to be thoroughly cut up and pulverized. Teeth at front and rear can be regulated to work at the same depth. 


\section{ACME PULVERIZING HARROW}

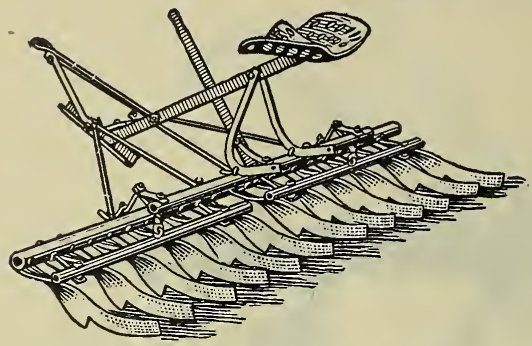

Is not a special tool as some have supposed, but as its name implies, a general purpose harrow that will do the whole business, viz.: it will crush, cut, lift, turn, smooth and level, all in one operation.

While pre-eminently adapted for heavy, stubborn land, it can be adjusted by means of levers and runners to do perfect work on the lightest soil. The peculiar shape and arrangement of the Coulters insure the cutting over of the entire surface of the ground, and owing to the absence of spike, spring, or pointed teeth, there is little, if any, tendency to disturb sod or trash that has been turned under by the plow. It not only prepares a perfect seed bed, but will also cover seed in the best manner.

It will be observed that the Coulters all slope backwards, thus presenting the least possible resistance, and as they are beveled and ground to an edge, the draft is reduced to a minimum.

Being made entirely of cast steel and wrought iron, it is practically indestructible. Nothing but the Coulters can possibly wear, and these are readily replaced at a trifling cost.

The No. 23 illustrated is adapted to both light and heavy soils, having two gang bars and being therefore flexible. By means of braces attached to bars the No. 23 may be made into a rigid harrow. It is $61 / 2$ feet wide. A variety of sizes are made, working 3 feet to $131 / 2$ feet wide, adapted to small as well as large farms and to the orchard and garden.

\section{THE DANDY DISK HARROW}

Is everything that its name implies, in the way of being the neatest, the simplest in construction, the LIGHTEST RUNNING, and at the same time the STRONGEST and MOST DURABLE Harrow made. . . . It has many advantages over the wood frame harrow, and in addition will last longer. This harrow is made of steel angles, extra heavy cross-beam of steel tubing. No wood about it but the tongue and the hitch. While almost any disk harrow will do fair work under the most favorable circumstances, only the BEST will stand the test at all times and under all the various conditions of soil. We guarantee the DANDY to be equal to any work that it is possible for a disk harrow to do and do it WELL.

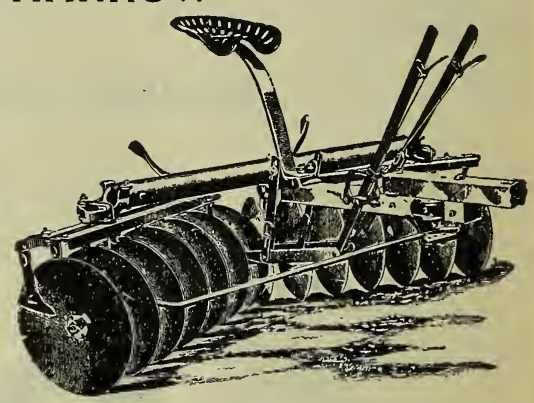

The cut shows the harrow, giving the construction in detail, including the most perfect set of Gang Scrapers made. To give additional strength, all harrows have heavy brace rods drawing from the lower part of the stands instead of the top.

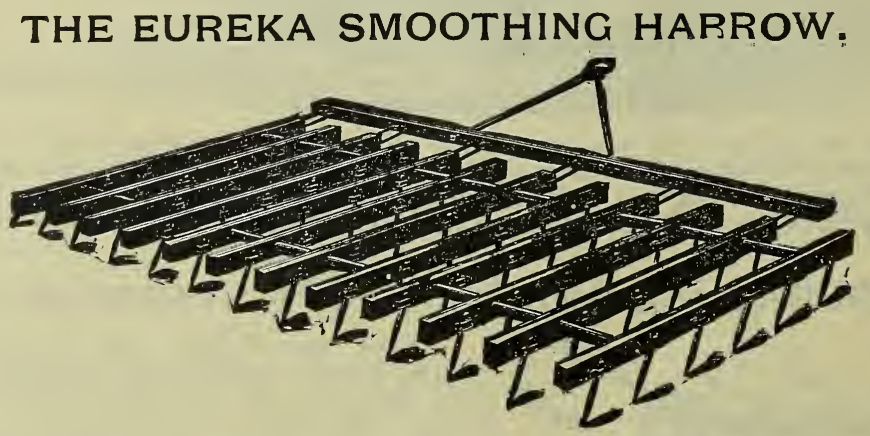

We regard the "Eureka" as the best pattern of Smoothing Harrow in market. The teeth are 9-16 round, and are attached to the side of bars by a malleable clasp, and are so arranged that by hitching to one end of the harrow the teeth pull slanting, as shown in the cut. By hitching to the other end, the teeth pull straight.

The teeth being convertible merely by change of hitch from perpendicular to slanting, it combines all the principles of two harrows in one. The superiority of having teeth in a slanting position is beyond doubt or question, as they cut and pulverize the soil thoroughly without clogging, leaving the trash under the soil.

It is also excellent for cultivating corn, potatoes, and other crops when small. 


\section{ECLIPSE IMPROVED CORN PLANTER AND FERTILIZER DISTRIBUTOR.}

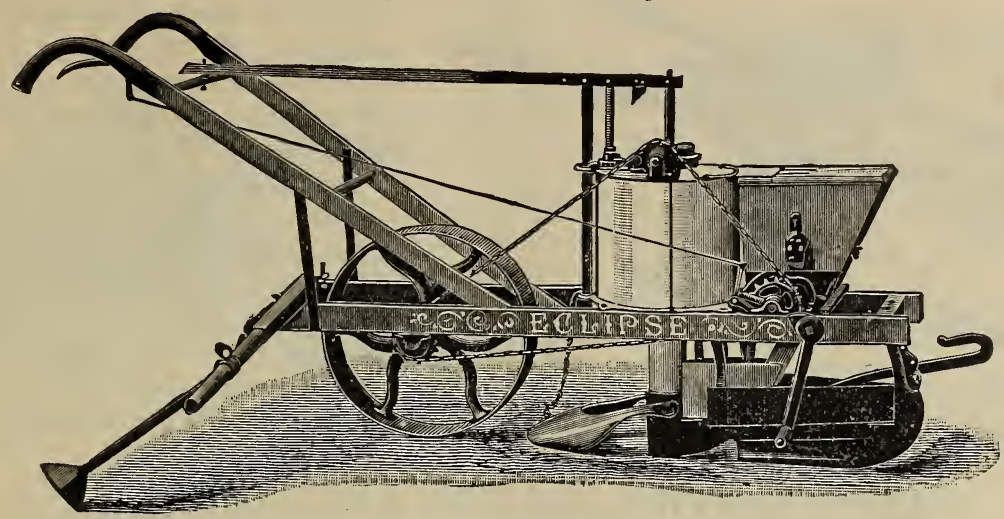

It is the only planter that will accurately distribute all commercial fertilizers wet as well as dry, pulverized hen manure, plaster, ashes, etc., in given amounts per acre in hill, drill or check. The seed is deposited in the centre of the furrow made by the plow, which is constructed with concave places on each side in front of seed gate. These form beads of moist earth which are cut off by knife edge just back of seed gate and fall on the seed. The fertilizer is then dropped on each side of the seed. The planter will drop in hills from 6 to 45 inches in distance. The marker attachment is simple and easily shifted from side to side. The spaces on the arm are marked with figures every two inches from 28 to 48 inches.

\section{STROWBRIDGE BROADCAST SEED SOWER.}

Sows grass seeds, oats, barley, rye, etc., also fertilizers, land plaster, salt, lime and ashes. This machine is readily attached to the tail-board of a wagon. Sows eighty acres of grain a day, better and faster than any other method; perfectly simple.

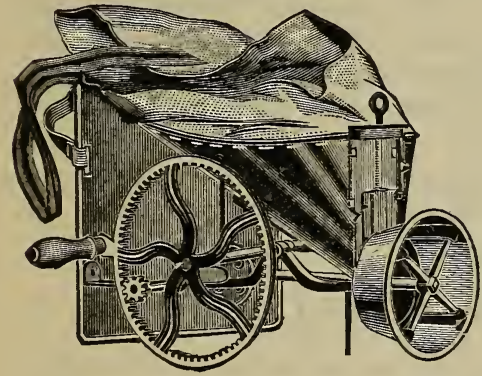

\section{PEARCE'S IMPROVED CAHOON SEED SOWER.}

\author{
For Sowing Wheat, Barley, Oats, Buckwheat, \\ Rye, Grass Seed, Etc.
}

Sows from four to eight acres per hour at a common walking gait, throwing out wheat a distance of forty feet wide. These machines are the acknowledged superior to all others of their class and by their use a saving of four-fifths the labor and one-third the seed can be effected. A person entirely unused to sowing by hand can use this machine with perfect success.

\section{THE CROWN SEED SOWER.}

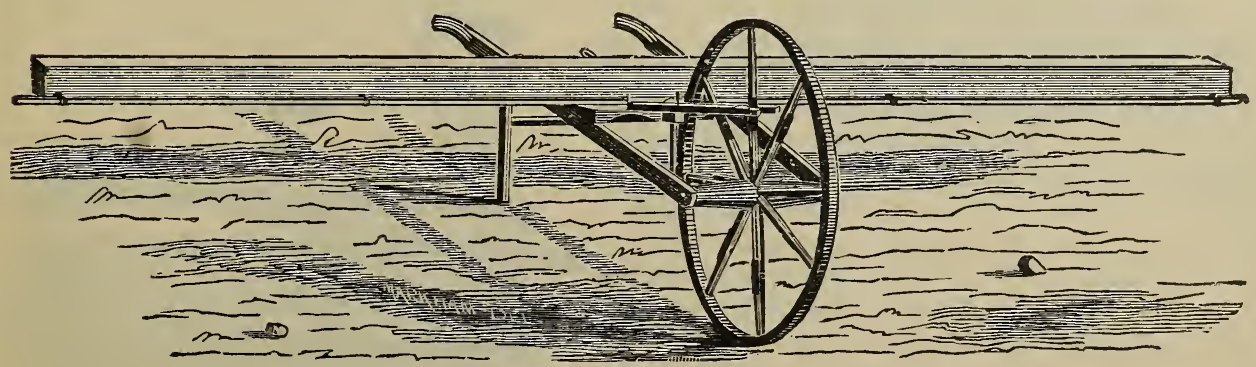

No farmer who sows grass seed can afford to be without this simple and effective machine. Quantity can be gauged from two to tweive quarts per acre. Sows twelve feet wide, and as accurately as a force feed drill. Runs light, weighs $40 \mathrm{lbs}$., will sow from fifteen to twenty acres per day; can be used in wet, dry or windy weather; it is made and finished in a superior manner. 


\section{ADVANCE FERTILIZER DRILL.}

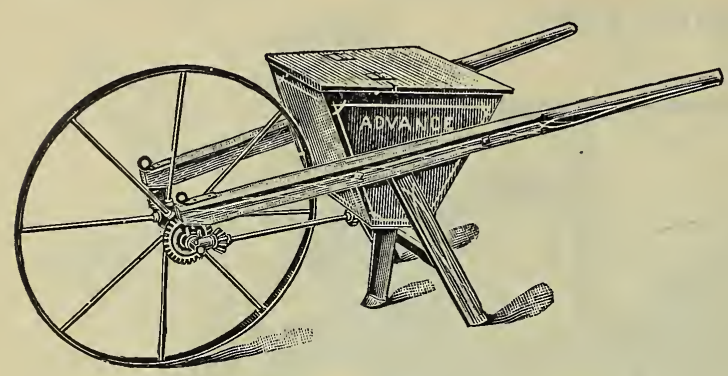

The increased use of commercial fertilizers has fairly compelled the farmer and planter of the present day to provide himself with improved appliances for properly and economically distributing them.

We claim the "Advance" to be the best low priced distributor on the market, and would call attention to its distributing disk of galvanized iron, which can neither break nor rust; also to the wrought-iron wheel, light and strong.

A shut-off, to prevent the escape of fertilizer when wheeling around end of row, is a late improvement; one of those little things which go far, however, in making a tool valuable.

A first-class tool for the drilling of peas and corn.

\section{THE KEYSTONE ADJUSTABLE WEEDER.}

The "Keystone" is the only weeder that is adjustable to any depth and width and having no shafts can be worked close to the fence. It can be used as a shallow cultivator-working close to the plants between the rows until the crops mature-long after other weeders are laid aside. The long curved spring teeth are so placed and shaped that clogging is impossible, and the weeder being $\mathrm{V}$ shaped makes it a stronger tool than the straight framed weeders and adapts itseif to uneven surfaces much better. It does

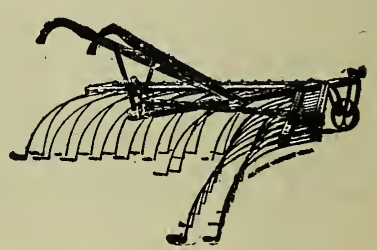
thoroughly and completely these two things - kills the weeds and pulverizes the surface of the ground. Where the soil is of a stiff clay nature we would recommend the flat tooth with the diamond points, as soil of this nature requires a more rigid tooth.

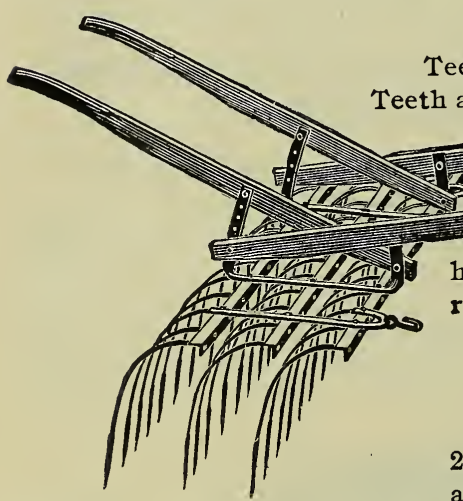

\section{HALLOCK SUCCESS WEEDER.}

Teeth are separately removable. Handles and shafts adjustable. Teeth are made of flat spring steel (round at lower end). The frame is angle steel, giving the Weeder by far the best frame on the market. It weighs no more than wood and is, of course, better in every way. Each tooth is secured to the frame independently of the other, hence you can in about two minutes remove the teeth over the rows if you wish, and in some cases it is very desirable.

\section{DUNHAM LAND ROLLERS.}

The Dunham 2 to 4 -Horse Roller is made in seven lengths, $20,24,26,30$ and 36 inches in diameter and in $2,3,4$ or 5 sections, according to length. The weight boxes are 3 -inch angle steel

with steel brackets having removable hard maple journals, and malleable oil cups. The steel bracket has a cap which goes over the end of the axle same as on a mower. The drums are made of No. 11 United States gauge steel, guaranteed not to dent, and all shafting is $13 / 4$ inches diameter, and lathe-turned. The above features together with the extra long pole braces, clip on rear end of pole and counter balance, place the Dunham ahead. The 1 -Horse size is made in 1, 2 and 3 sections, 20,24 or 26 inches diameter, and is largely used in rolling parks and large private lawns. All these rollers are equipped with doubleleaf seat-springs, making them easy riding and at the same time taking all weight of tongue off horses'
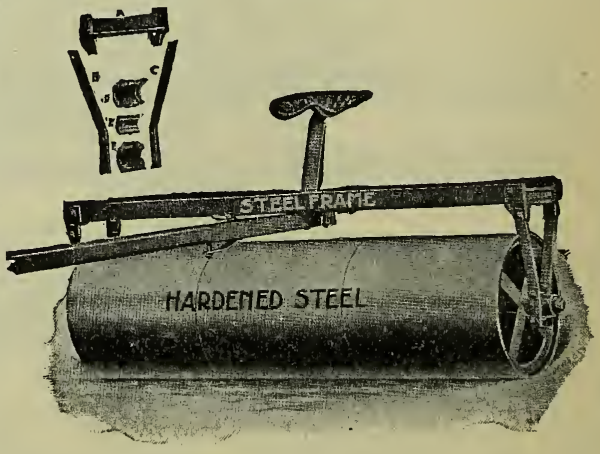
necks. We carry in stock the 7 feet 3 -section, but can supply at short notice any of the other sizes. 


\section{IRON AGE (Improved Robbins) POTATO PLANTER.}

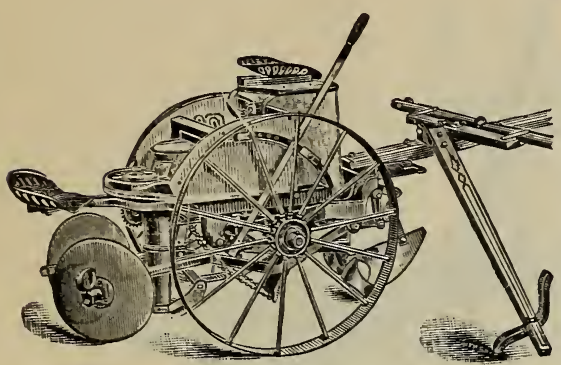

Old-Time Methods. - It is needless to speak of the slow, laborious method of potato planting as practiced by the large majority of growers; of the consequent improvident waste of time at the opening of the busy season, and the interference caused by the uncertain weather of early spring. When the proper season arrives the potato grower should be prepared to do his planting promptly and with as little delay as possible. On the other hand, the potato crop is so costly - costly in high-priced seed, thorough preparation of soil, frequent cultivation and application of insecticides, followed by expensive harvesting of the crop - it behooves the grower to "make haste slowly." He wants machinery to aid him, but that machinery should be of such a character that the quality of work must be unquestioned.

Both Quality and Quantity.- It must be quality as well as quantity. With the "IRON AGE" (Improved Robbins), however, the farmer has the comfortable assurance of attaining both, easily planting with it from four to seven acres per day, and such perfection of potato planting was never before accomplished. It is simply ideal.

The Plow throws out on each side a free furrow of loose soil with no packing or wedging to crowd the future growth of the crop, and has an independent adjustment by which its position can be changed to suit the different depth of furrowing in different soils.

A Perfect Fertilizer Distributor.-The fertilizer is placed in a round hopper of galvanized iron and is fed downward through a central opening formed by a straight agitator shaft. This feeding is accomplished by a winged scraper, which descends by its own gravity as the material is fed away, while the fertilizer falling upon a cone in a light, loose condition, is thrown by this cone outward on to a revolving disk, which in turn carries it to the gate opening at its edge.

Dropping Seed.-Then follows the drill tube through which the seed is dropped, this tube being provided with a small hoe which opens a narrow groove in the bottom of the furrow and into which falls the seed. The small shoe also divides the fertilizer, preventing it from coming in direct contact with the seed and mixes it with the soil in passing. Then immediately following comes a pair of large steel disks, which cover the seed with light, loose soil.

\section{IRON AGE POTATO DIGGER.}

It will be noticed the "IRON AGE" digger is designed upon novel lines and different from potato diggers heretofore offered. We wish to emphasize just at this point an important feature of this machine, aside from its mechanical construction - it being a Combination Low Down and Elevator Digger. This, we believe, is an entirely unique idea and something never before attempted. We feel safe in stating that to satisfactorily dig a large majority of the potatoes grown, taking the country as a whole, an elevator digger is not required with its attendant disadvantages, increased draft, excessive cost of repairs, unnecessary handling of the potatoes, etc. There-

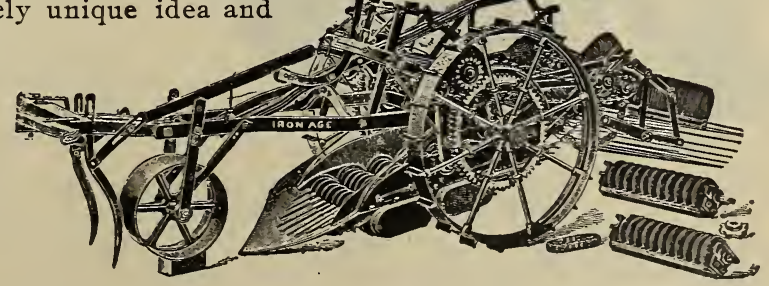
fore, under such circumstances the "IRON AGE" digger is used as a Low Down digger; but when it meets those conditions where an elevator digger is absolutely necessary, in order to get satisfactory separation, the elevator attachment shown may be quickly applied, thus placing in the hands of the operator a perfect elevator digger. As a Low Down digger the "IRON AGE" is emphatically a two-horse machine, because of the easy rotary motion of the separating disk's and the slight increase of elevation. Under any condition, with the elevator attachment applied, our digger may be operated by three horses instead of four as are usually required by other elevator machines. 


\section{THE DEERING IDEAL MOWERS.}

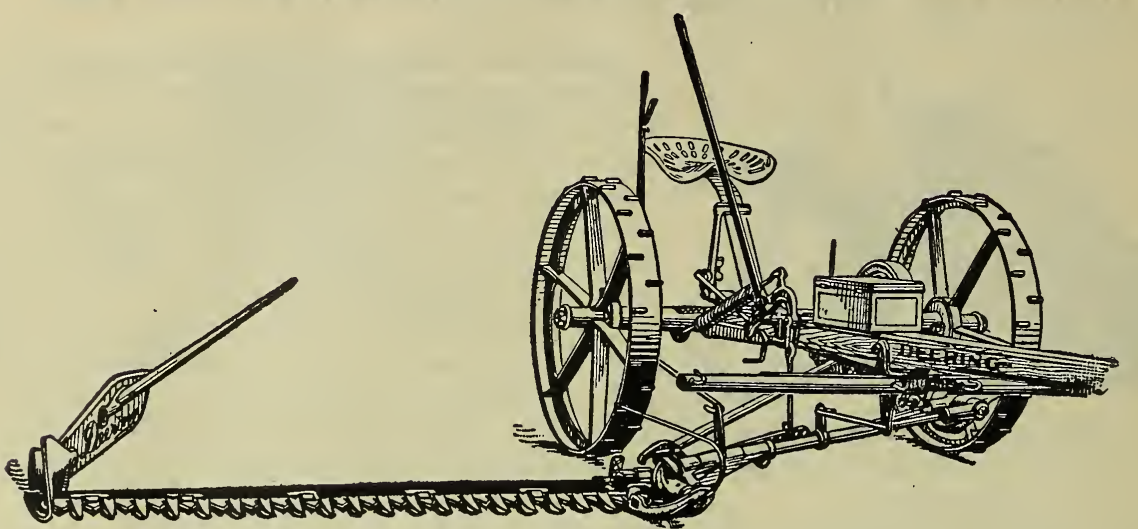

One of the most valuable features of the Ideal Mower is its perfect foot-lift, by means of which the lifting lever is rarely called into use. The Deering foot-lift connects with a coil-spring which carries the weight of the bar and assists in raising it, besides doing away with side-draft which results from heavy pressure on the ground. By the use of the horizontal crank-shaft on the Deering Mower, all rocking or vibrating motion to the pitman is obviated, thus rendering unnecessary the use of the swivel connection which results in frequent breakages of the pitman and knife-head. The Deering pitman operates in a direct line without cramping, no matter how the cutter bar is tilted. It is made from the best second growth hickory, with couplings of forged steel. It is well protected by the drag-bar. A few of the many other good points of the Ideal Mowers are an adjustable drag-bar, spring-steel clips, steel wearing plates, serrated ledger-plates and a floating cutter-bar. These special points of merit refer equally as well to the one-horse mower as to the two-horse, and where the acreage is small the one-horse machines are of great service. They are largely used as a horse lawn mower for golf links, parks and cemeteries. We invite careful inspection of these machines and will be pleased to mail to all who are interested the Deering Catalogue. Prices on application.

\section{DEERING BINDER TWINE.}

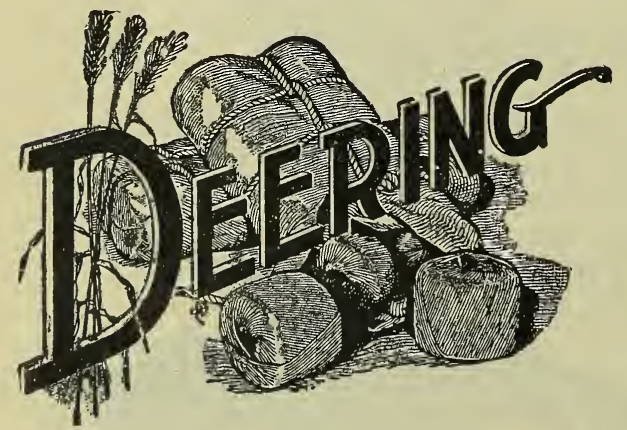

The Deering Twine will be found to be uniform in quality and reliable in every respect. It is noted for its high quality and is cheap in the sense that it goes farther than other makes, is more reliable, and farmers who use it have smaller twine bills than those who use the socalled "cheap" twines. Every ball of Deering Twine is of guaranteed length. In fact, it is just what the tag says it is.

We will mail to all who are interested the Deering Twine Booklet, which contains much valuable information upon the manufacture of binder twine.

\section{RUDDY HARVESTER OIL.}

Ruddy Harvester Oil is made especially for mowing machines, reapers and other kinds of farm machinery and has never failed to give satisfaction. The oil is pure, free from grit, and is warranted not to gum or injure the finest machinery. Beware of the so-called mowing machine oils usually offered by agents. By using them you will damage your machinery.

Ruddy Harvester Oil is put up in convenient cans ready for use, as follows:

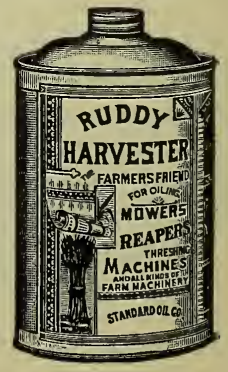




\section{DEERING IDEAL SELF-DUMP RAKE.}

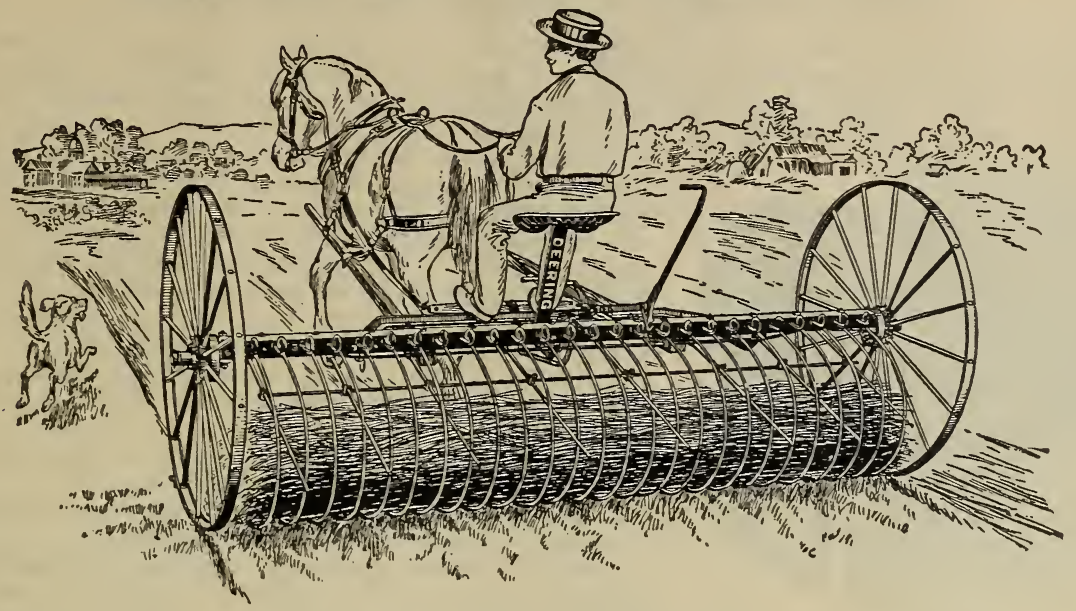

No rake has ever been built that is as simple in construction and operation as the Deering Ideal Rake. It is especially adapted for heavy bunching, as owing to the height at which the teeth are carried a larger windrow can be made than with any other rake. Its adjustments allow it to do clean work on side hills. A superior quality of steel clips each secure a number of rake teeth, leaving but few nuts to watch and tighten as compared with singly secured teeth. The Ideal Rake wheels are interchangeable, can be used on either side of the rake and are provided with renewable sleeves that can be replaced at small expense. The frame is of angle steel and the teeth are oil-tempered. Full descriptive catalogue of these rakes will be mailed on request.

\section{THE "O. R. C." HAY TEDDER.}

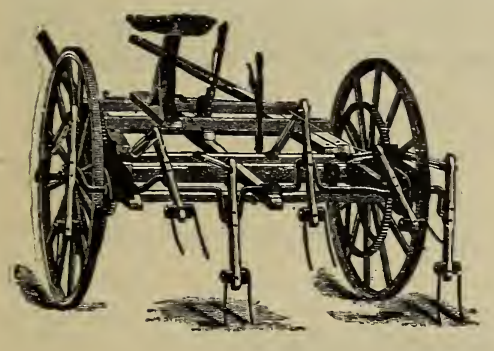

The "O. R. C." Tedder is unexcelled for strength and durability, ease of draft and quality of work done. The Ground Wheels are closer together than on most Tedders, and this makes a stronger, better machine; better for working uneven ground, besides no hay is pressed down to the ground by the wheels - the outside teeth kick it up loose after the wheels pass over it. In a moment this tedder can be changed from shafts for one horse to a pole for two horses. The forks are made of crucible steel, oil tempered.

\section{THE DEERING HAY TEDDER.}

The main frame is made of heary angle steel, solidly riveted together. Rivets are used on

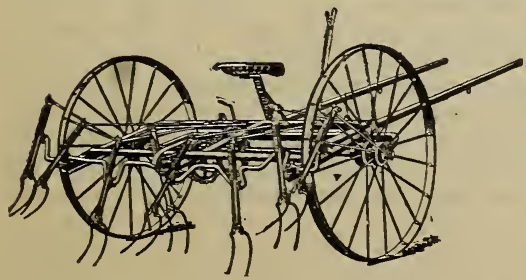
this tedder wherever practical instead of bolts, in order to prevent the possibility of trouble caused by bolts becoming loosened. The wheels are high with a channel tire and the spokes are widely staggered.

The forks are made of the best spring steel procurable, and so attached that, should they strike an obstruction, a coiled spring will prevent them from breaking. The main frame will also tilt up and relieve the forks should the teeth come in contact with the ground. The end forks are outside the wheels. A convenient hand lever permits the forks to be adjusted to any desired height above the ground. Each fork gets for tedding all the power of both wheels, as the drive gears operate all the forks and are centrally located on the axle. 


\section{CYPHERS INSURABLE INCUBATORS.}

Cyphers incubators, since first introduced, have borne an unequalled reputation so far as the fire risk is concerned, as established by the affidavits of agents and salesmen and as confirmed by the records of the insurance companies; therefore, the standard type of incubator manufactured by this company fared well at the hands of the mechanical and consulting engineers. Nevertheless, they

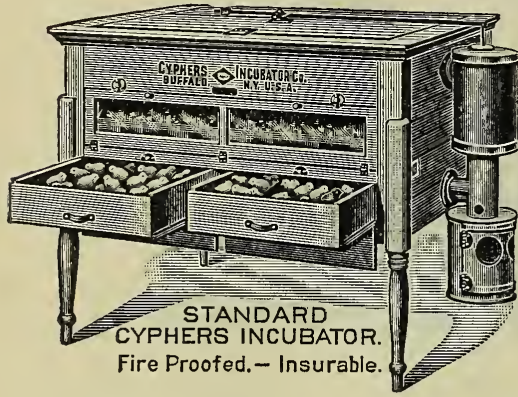

No. 6. So that the lamp can be "readily removed and replaced by the operator without spilling of oil." minor changes in the location and insulation of the heater, and to require the adoption of a method of fire-proofing the heater end of the standard Cyphers in such manner as would accomplish the following important results:

No. 1. So that fire from the oil flame (or lamp) "cannot communicate to the incubator case."

No.2. "So that oil cannot drip from the lamp, nor fire communicate therefrom to the floor of the room in which the incubator is operated."

No. 3. So that the lamp "cannot be filled without removal from the incubator" or lamp support.

No. 4. So that the lamp "cannot be accidentally jarred or dislodged" from the support.

No. 5. So that the lamp "will at all times be held in proper position and alignment" with the heat flue to heater. wished to make doubly sure of safety in the use of even the standard Cyphers, hence saw fit to require several

\section{CYPHERS INCUBATOR COMPANY}

Is the first in the world to build incubators and brooders that meet the requirements of the associated fire insurance interests and is the first company in the history of the poultry business to be granted labels by the fire underwriters, covering inspected and approved incubators and brooders that have satisfactorily stood the test and met the requirements of their expert engineers. Label No. 1 for "Inspected Incubator" and label No. 1 for "Inspected Brooder" have been issued to Cyphers Incubator Company. No two labels issued for incubators and no two labels issued for brooders are to have the same number.

This means that every incubator and every brooder that bears the fire underwriters' official label must be one that has been inspected and approved by representatives of the Underwriters' Laboratories (Inc.).

PRICES.

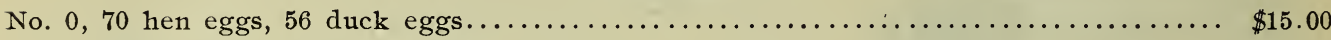

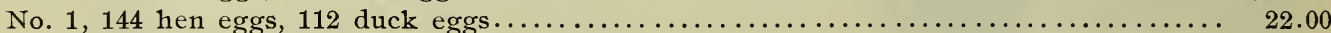

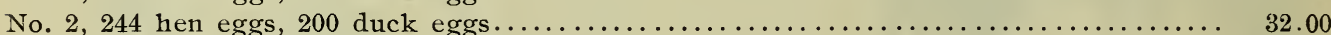

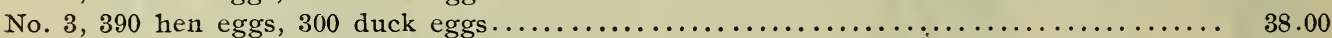

\section{CYPHERS FIRE-PROOFED BROODERS.}

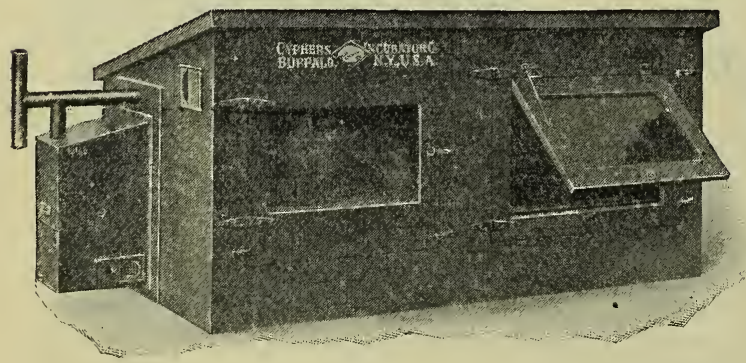

PRICFS.

Cyphers Incubator Company has designed a line of improved brooders that embody the most advanced ideas known to date in brooder construction. They are built to do the work required of them, cost price being treated as of secondary importance. These brooders are based on many years of practical experience and not only are fire-proofed and insurable, but are claimed by the manufacturers to be the best designed, the most durable, the most convenient and the most efficient indoor and outdoor individual brooding devices thus far invented and placed on the market.

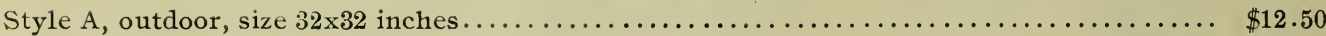

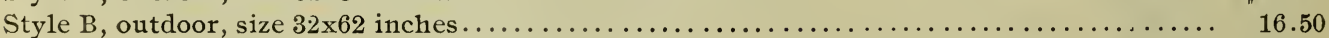

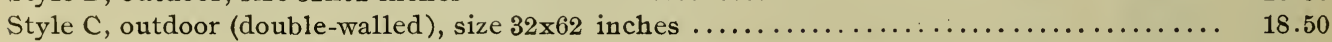

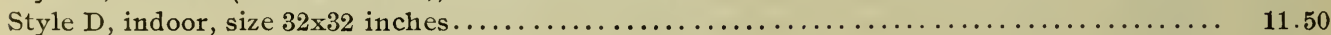

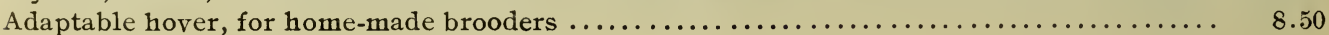




\section{STANDARD AND RELIABLE POULTRY SUPPLIES.}

We have omitted the prices of Foods in large quantities, as prices, especially of grains, fluctuate continually. For a complete list of our extensive line of Poultry Supplies ask for our Poultry Supply Catalog. It's free.

\section{FOODS.}

Animal Meal (Bowkers). 10 lbs., .50; 25 1bs., $\$ 1.00$; 50 1bs., $\$ 1.50$; 100 1bs., \$2.50.

Bone. (Mealed.) The use of Ground Bone tends to keep fowls in good health and materially aids laying hens. 5 1bs., .25; 25 lbs., .63; 50 lbs., $\$ 1.25$.

Buckwheat. For pigeons and young poultry. Per qt., .10; pk.,.30; bu., $\$ 1.10$.

Clover Meal (Alfalfa), Cyphers Quality. 5 1bs., .20; 25 1bs., .75 ; 50 1bs., $\$ 1.30$.

Clover Hay (Alfalfa). Excellent food for winter and early spring. 5 1bs., .20; 25 lbs., .75; 50 lbs., $\$ 1.15$.

Chick Food (Cyphers'). A complete food for young chicks. 5 1bs., $.25 ; 10$ 1bs., .40; 25 lbs., .75; 50 lbs., $\$ 1.50$.

Developing Food (Cyphers'). For hastening the growth of young stock. 5 1bs., .20; 10 lbs., .35; 25 lbs., .75; 50 lbs., $\$ 1.30$.

Scratch Food (IXL). An ideal grain mixture. 5 1bs., .20; $101 \mathrm{bs}$., $.35 ; 25$ 1bs., .75; 50 1bs., $\$ 1.30$.

Laying Food (Cyphers'). A complete balanced ration from which to make the morning mash. 5 1bs., .20; $101 \mathrm{bs} ., .35 ; 251 \mathrm{bs} ., .75$; 50 1bs., $\$ 1.30$.

Forcing Food (Cyphers'). For inducing 'rapid growth as in growing broilers or roasters. 51 bs. $.20 ; 10$ 1bs., $35 ; 25$ 1bs., 75 ; 50 1bs., $\$ 1.30$.

Beef Scraps (Cyphers'). 5 1bs., .25; 10 1bs., .40; 25 1bs., \$1.00; 50 1bs., \$1.75; 1001 bs., \$3.00.

Beef Scraps (IXL). 5 1bs., .20; 10 1bs., .35; 25 1bs., .75; 50 1bs., $\$ 1.40 ; 100$ 1bs., \$2.65.

Hulled Oats. Market price.

Hemp Seed. Largely used for feeding birds and pigeons. Qt., .10; pk., .60; bu., $\$ 2.00$.

Kaffir Corn. Excellent poultry and pigeon food. Qt., .10; pk., .50; bu., \$1.50.

Grit (Mann's Crystal). Package, .10; 25 1bs., .25; 50 1bs., .40; 100 1bs., .65.

Oyster Shell. Package, .10; 25 1bs., .25; 50 1bs., .40; 100 1bs., .75.

Peas (Canada Field). Qt., .10; pk., .50; bu., $\$ 2.00$.

Sunflower Seed. Qt.,.10; pk.,.50; bu., $\$ 1.50$.

Full Nest Egg Food (Cyphers'). Try it and get more eggs. 42 oz. pkg., .25 ; 251 b. pail, $\$ 2.00$.

Egg Maker (IXL). Increases egg productior. 42 oz. pkg., .25.

Egg Maker (Lee's). A standard and reliable preparation. 21/2 1b. pkg., .25; 251 b. pail, $\$ 2.00$.

Charcoal. (Granulated or pulverized.) Pkg., .10; 10 bs., .40; 25 1bs., .75; $501 \mathrm{bs} ., \$ 1.25 ; 10 \mathrm{C}$ 1bs., $\$ 1.75$.

Millet. Excellent for little chicks. Qt., .10; 5 lbs., .25; 101 bs., .40; 251 bs., $\$ 1.00 ; 501$ bs., $\$ 1.75$.

\section{'ROUP CURES, LICE KILLERS AND DISINFECTANTS.}

Roup Cure (Cyphers'). .50 and $\$ 1.00$ per package.

Roup Cure (Conkey's). .50 and $\$ 1.00$ per package.

Roup Cure (IXL). .50 and $\$ 1.00$ per package.

Death to Lice (Lambert's). $.25, .50$ and $\$ 1.00$ per package.

Lice Powder (Cyphers'). $.25, .050$ and $\$ 1.00$ per package.

Lice Powder (IXL). .25, .50 and $\$ 1.00$ per package.

Lice Killer, Liquid (Lee's). Qt., .35; 1/2 gal., .60; 1 gal., \$1.00.

Lice Killer, Liquid (Cyphers'). Qt., .35; $1 / 2$ gal., .60; 1 gal. , $\$ 1.00$.

Lice Killer, Liquid (IXL). Qt., .35; $1 / 2$ gal., .60; 1 gal., $\$ 1.00$.

Napcreol (Cyphers'). A concentrated preventive of disease. Qt., .50; 1/2 gal., .85; 1 gal., $\$ 1.50$.

Taroline (Conkey's). A standard disinfectant. Pt., .35; Qt., .60; 1/2 gal., .90; Gal., \$1.50.

\section{EGG BOXES.}

Imperial. For shipping sittings of eggs. Made of wood. 15 -egg size, each,.25; doz., \$2.25; 30-egg size, each, . 30 ; doz., $\$ 2.75$.

Eyrie. For shipping sittings of eggs. Made of heavy corrugated cardboard. 1 sitting, each, .15; doz., $\$ 1.20$; 2 sittings, each, .20; doz., $\$ 1.90$.

Ideal (Paper). For use in delivering eggs to private families. 1 -doz. size, per doz., $.15 ;$ per $100, \cdot 75$.

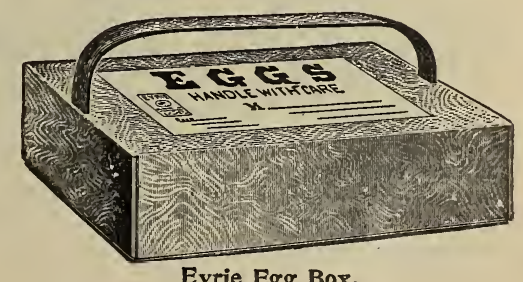

Eyrie Egg Bex.

We carry the Largest and most Varied Assortment of Poultry Supplies to be found in Rhode Island. 


\section{IMPROVED "PITTSBURGH PERFECT" POULTRY AND GARDEN FENCE.}

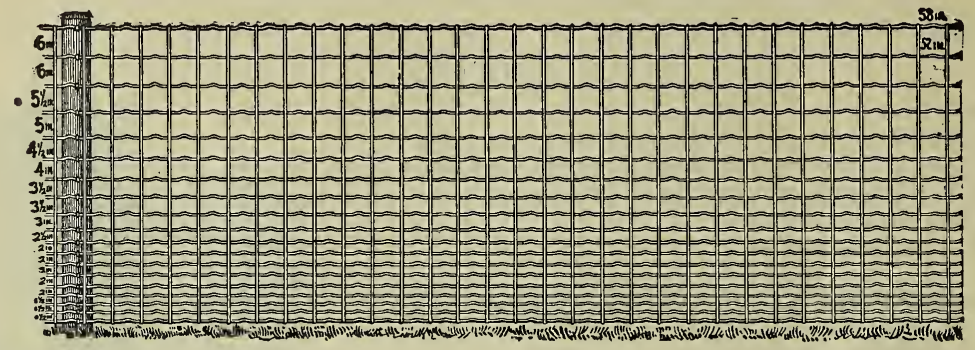

You get in the "Pittsburgh Perfect" Poultry and Garden Fence that "Perfect" galvanizing and the "Perfect" electrically welded joint and "Perfect" workmanship, and above all a certainty of "Perfect" satisfaction if you use it. We know that it is close enough at the bottom to keep in the smallest chicks, and you need no top or bottom boards. Notice the heavy wire on the top and bottom (No. 10 wire); that explains it. Notice the spacing between the horizontal wires; nothing can get through the lower strands; and as the spaces get wider they are too far from the ground for chickens to get through. Surely it is a "Perfect" Fence, the best on the market, and the price extremely reasonable. The best, strongest, neatest, most durable. It is in a class of its own. The only electrically welded poultry and garden fence. Spacings between strands from bottom to top in inches are $1 \frac{1 / 2}{2} 11 / 2,1 \frac{1}{2}, 2,2,2,2,2,21 / 2,3,31 / 2,31 / 2,4,41 / 2,5,51 / 2,6,6$.

It is made in five heights, 24 in., 36 in., 46 in., 52 in., 58 in. With stay wires 6 inches apart only.

Height 36 in.

PRICE PER ROLL OF 10 RODS EACH.

46 in.

$\$ 4.40 \mid$ Height 52 in.

$5.00 \quad$ " 58 in.

$\$ 5.50$

5.75

\section{"PITTSBURGH PERFECT" SPECIAL POULTRY AND GARDEN FENCE.}

Same as above, except wires are one size lighter. The very best value ever offered in the very best grade of fence on the market is in the "Pittsburgh Perfect" Special Poultry and Garden Fence. Just think of it! A good substantial fence, chicken tight, good enough for stock, top and bottom wires No. 11, all other wires No. 14. All galvanized wires and cheaper than poultry netting. It is the neatest, prettiest, strongest, best cheap poultry fence on the market.

PRICE PER ROLL OF 10 RODS EACH.

Height 46 in. . . $\quad$ Height 58 in. $\$ 4.15 \mid$ Height 52 in..$\quad$. $\$ 4.80 \quad . \quad$. $\quad . \quad \$ 4.50$

\section{TRADE STERLINGWORTH NAME FLY DRIVER AND GERM DEATH.} FLY KILLER AT 25 CENTS A GALLON.

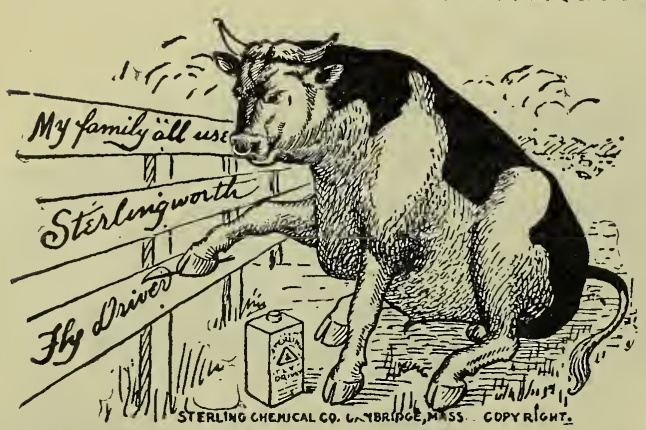

Sterlingworth Fly Driver and Germ Death completely protects cattle and horses from all winged pests. It is non-poisonous, harmless, easily applied and lasts longer than any other fly driver sold for three times its price. It does not burn or gum the animals'coat or contaminate milk, and is equally good for horses as for cattle.

Sterlingworth Fly Driver protects mostly by evaporation. The fumes from it do the work. The flies are driven before coming in contact with the animal. Flies sprayed with the fluid are killed. Its use on milch cows protects them from shrinkage during fly time.

Sterlingworth Fly Driver is put up in one and two quart cans. The contents of the one quart cans, when mixed with water as wanted, make two gallons of fly driver. During the season when flies are especially troublesome a stronger mixture may be prepared by using two quarts to three gallons. While cattle are indoors a weaker solution of two quarts to five gallons will generally be sufficient. No other fly driver possesses these valuable advantages. To prepare, simply add quantity stated on the plainly printed directions to water. It may be mixed by the sprayer full as wanted, or the entire quantity prepared at one time. It may be applied with either a sprayer or with a whitewash brush, sponge or rag. The Acme sprayer described on page 36 is recommended as a good one for the purpose.

Try a can and you will say that it is the best Fly Driver you have ever used.

Prices: One quart can, makes two gallons Fly Driver, 60 cents; two quart can, makes four gallons, $\$ 1.00$. 


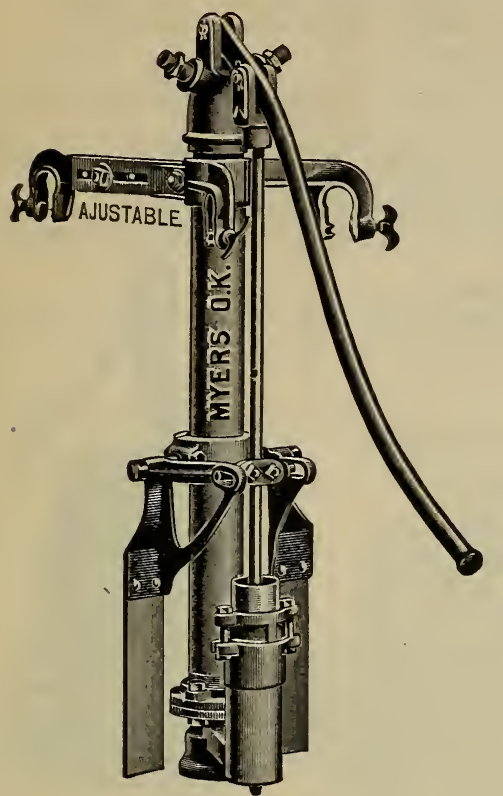

\section{MYERS' O. K. SPRAY PUMP.}

For Hot, Cold or any Kind of Mixture. Has Mechanical Agitator, Solid Brass Ram Plunger, Ground

Bevel Valve and Seat.

This pump is designed for ordinary orchard use, and, as will be seen by the cut, can be readily attached to any size of barrel in a minute's time; for that reason we sell it either with or without the barrel. The cylinder is what is known as a ram plunger, made of solid brass tube with closed end which passes through a circular hemp packing which adapts it either for hot or cold mixtures. It has a brass valve seat. The pump is fitted with leads for hose, but no hose is furnished at price printed.

Another special feature of this pump is that by removing two bolts the valves can be readily taken out and repaired. The air chamber is made of $2 \frac{1}{2}$ in. steel tube. The handle is wrought steel, so as to enable the operator to get up a pressure of 200 pounds or more if necessary.

We can furnish any length of hose desired at market prices.

Price of pump without barrel, $\$ 12.00$.

\section{THE "SUCCESS" WHITEWASH SPRAYER.}

This sprayer has Brass Cylinder, Brass Ball Valves, Malleable Handle, Detachable Brass Pump and an agitator for keeping the liquid stirred. The tank is galvanized and holds five gallons.

It is useful for applying the insecticides which do not affect iron, and is a successful outfit for disinfecting poultry houses, stables, etc.

This pump is furnished with a Bordeaux Nozzle, which is ideal for whitewashing work. Price complete as illustrated, $\$ 7.00$.

\section{THE AUTO-SPRAY.}

Made of either brass or galvanized steel.

This sprayer has nozzles, stop cock and fittings turned from solid brass, with deep cut threads, 3 ply rubber hose. The pump and valve are entirely of brass where they come in contact with the solution. All cast-iron parts are malleable iron. The carrying straps are made of 8-ply halter web. It is fitted with an improved valve and take-out and put-in sleeve, thus preventing damage or accident to the plunger and packing. In the brass machine there is absolutely nothing that can corrode or rust.

\section{What the Auto=Spray will do.}

A few strokes of plunger in air chamber will compress enough air to discharge the entire contents and make a continuous spray for nine minutes. This means that the "AutoSpray" can be charged in fifteen seconds, when it will work uninterruptedly long enough to spray a quarter-acre of potatoes. The spray can be made to flow fast or slow by merely turning the cock of the nozzle, and it will throw either a cloudlike shower or a solid stream.

\section{Prices.}

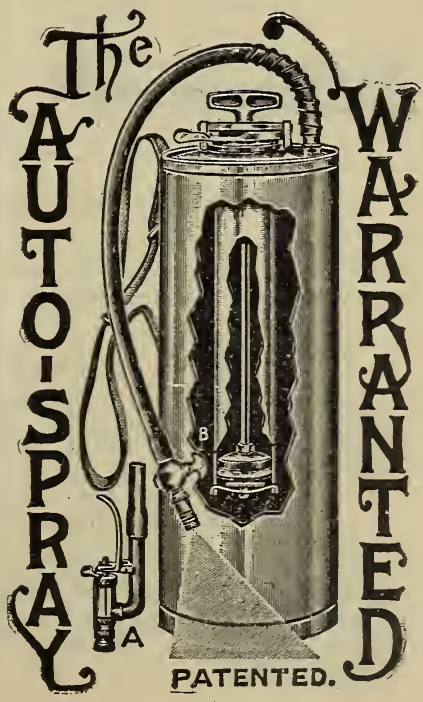

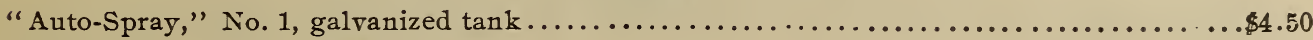

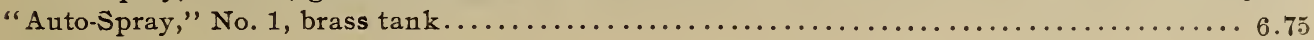

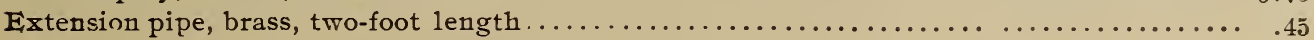




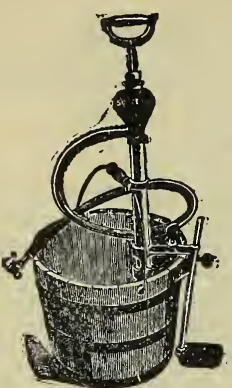

\section{THE PERFECT SUCCESS SPRAY PUMP.}

Price $\$ 4.50$.

This pump is furnished with the improved combination foot rest bucket clamp and bail holder.

The outfit is a most excellent one for ordinary use in the garden, vineyard or orchard and for washing windows, or the application of whitewash.

The combination bucket clamp and foot rest enables the operator to have the pump and bucket clamped together as one outfit with the bail standing upright.

It has a large air chamber and throws a continuous stream either in a spray or solid. It is provided with a Bordeaux Nozzle and four feet discharge hose.

\section{DEMING SIMPLEX BARREL SPRAY PUMP.}

Price with $12 \frac{1}{2} \mathrm{ft}$. Hose, Nozzle and Pole Connection, $\$ 9.75$.

The outfit shown in the accompanying cut makes a first-class orchard sprayer at a low cost. It has an adjustable base to fit the top or side of any barrel, in which the pump rests. The air chamber is large, insuring a constant stream.

The working parts are made of brass and the pump is provided with the best agitator on the market.

The cylinder being brass lined, the piston rod brass cased and the plunger and valve solid brass.

The discharge is provided with a $\mathrm{Y}$ connection, a tight cap being furnished for use in case but one section of hose is used.

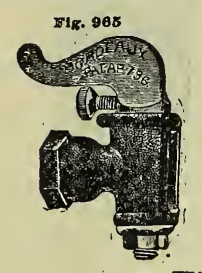

\section{The "Incomparable Bordeaux" Spray Nozzle.}

The "Bordeaux" Nozzle is the simplest and best combination spraying nozzle on the market. It throws a solid stream or a fan-shaped spray, adjustable to any fineness; is readily degorged by turning the cock handle. It will also throw a long distance coarser spray for spraying very large trees; or it may be shut off altogether - features possessed by no other spray nozzle.

Price, for $1 / 4$-in. pipe as per cut .

\section{The "Deming-Vermorel" Spray Nozzle.}

The " Deming-Vermorel " is an improvement on the Vermorel Nozzle. It is very simple in construction and throws a finer spray than any nozzle in use. Price, for $1 / 4$-in. pipe, as per cut

$\$ 0.75$

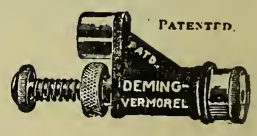

Nozzle Coupling and Hose Stock, Fig. 749.

This cut represents the hose stock for Spray Nozzles. Has 1/4-inch pipe thread, which fits all our nozzles. Opposite end for $1 / 2$-inch or $3 / 8^{-}$ inch hose, as ordered. Price, as per cut . . $\$ 0.25$

Combination Nozzle and Hose Coupling, Fig. 966.

This brass combination Nozzle and Hose Coupling will fit $1 / 2$ and $3 / 4$ inch male hose coupling. Has $1 / 4$-inch pipe thread on small end to fit our spray nozzles. Price, as per cut . . . . . . $\$ 0.25$
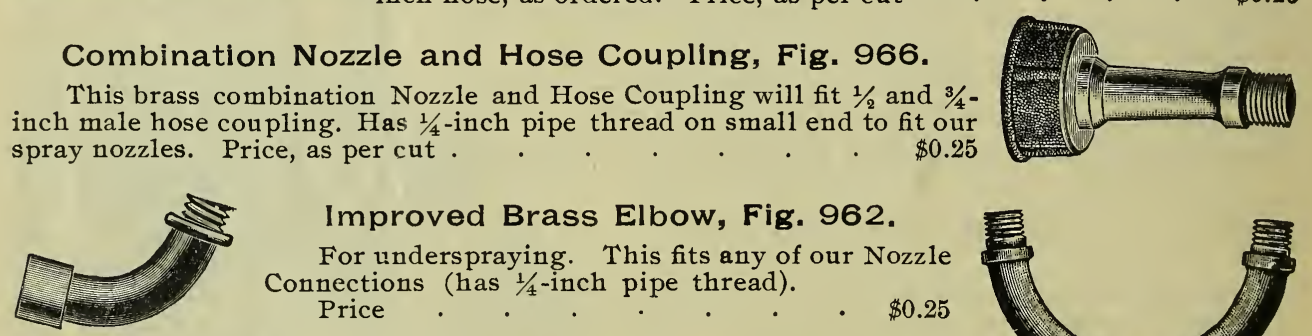

\section{Improved Brass Elbow, Fig. 962.}

For underspraying. This fits any of our Nozzle Connections (has $1 / 4$-inch pipe thread). Price

$\$ 0.25$

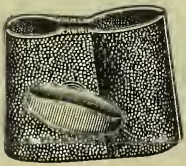

\section{Double Spraying Attachment, Fig. 980.}

The annexed cut represents a spraying attachment, Fig. 980, for two nozzles. Either Bordeaux or Vermorel may be used.

Price, as per cut

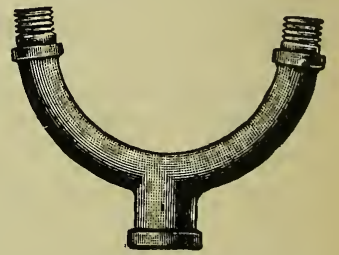

\section{Extension Pole Holder, Fig. 971.}

This improved attachment may be connected to and used with either Figs. 749 or 966 nozzle couplings shown above. For convenience in handling the hose may be tied to the pole.

Price, as per cut 


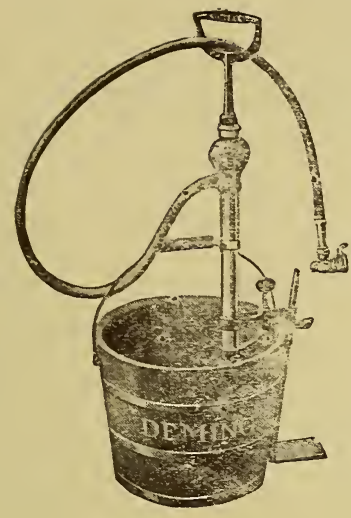

Fig. 689 .

THE “PERFECT SUCCESS" SPRAY PUMP. ADJUSTABLE FOOT REST. BRASS BALL VALVES.

HOPE, INDIANA, September 19, 1907 THE DEMINO COMPANY,

Gentlemen:--

Your letter of the 16 th to hand. I am pleased to report that the two "Success" Whitewashing Outfits I bought from you the past season have given me perfect satisfac. Uon; in fact, thave found these to be the most successful whitewashing machines i have ever seen or tried.

I have used nearly every machine in the market, bu1 have found the Deming "Success" the most satisfactory. I belleve that no poultryman can reaily afford to be without - we of these outfits.

I wish it were possible for me to talk to every poultry nersenally so as to advise him te place his order for a "Success" Outfit. I am

Yours respectfully,

U. R. FISHEL.

\section{Modern}

\section{Whitewashing.}

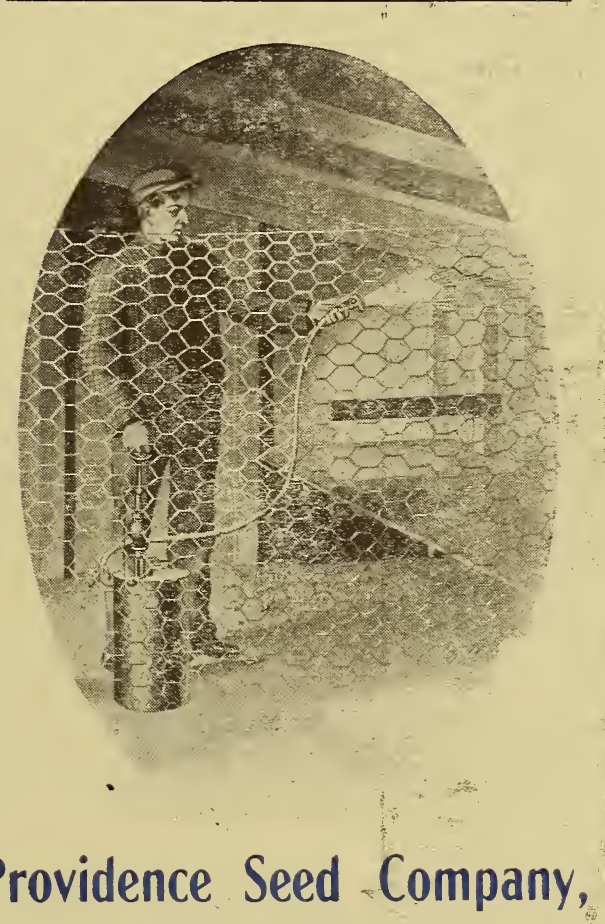

PROVIDENCE, R. I.

COMPLETE CATALOGUE ON APPLCATION 


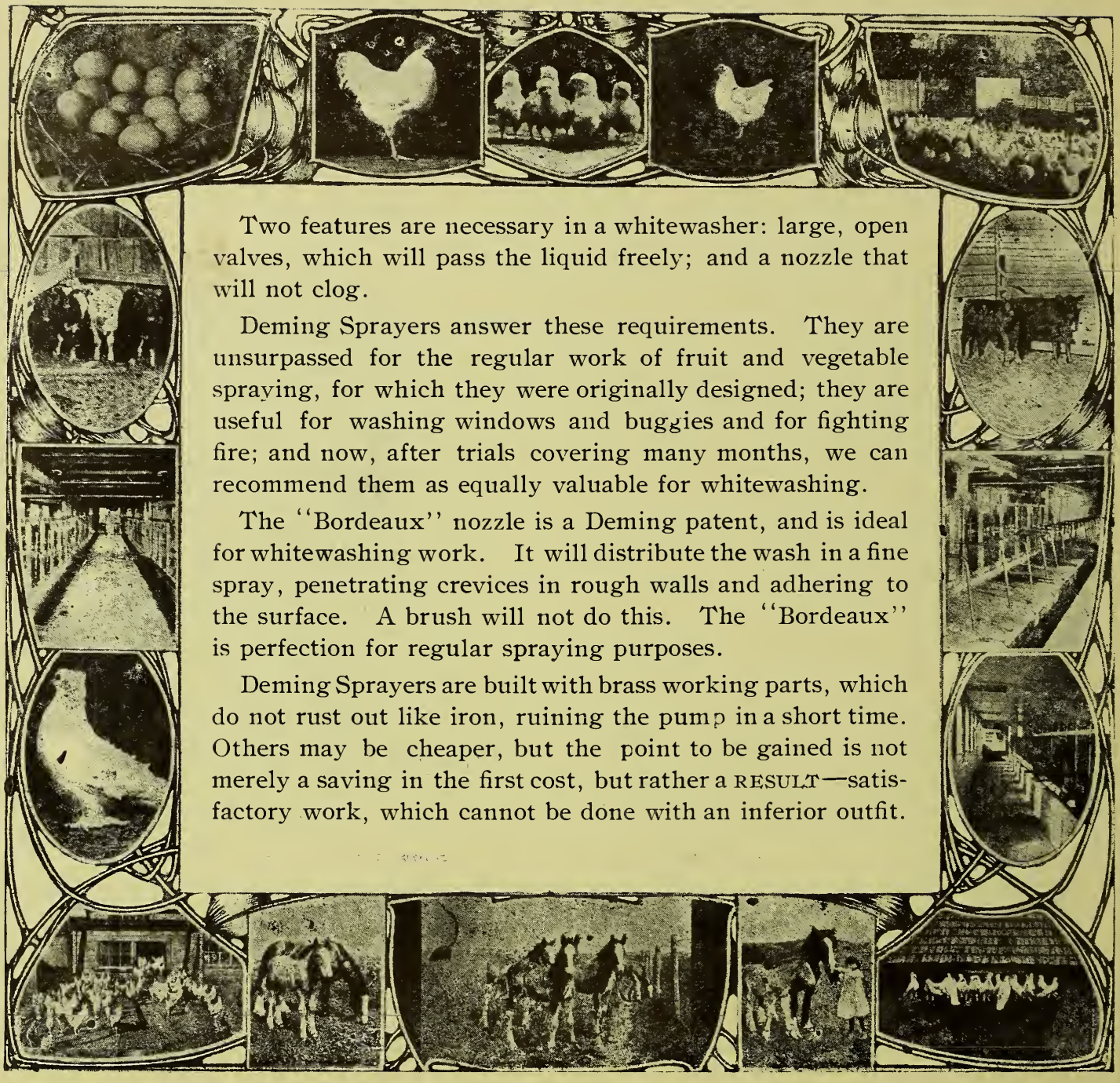




\section{INTERNATIONAL STOCK FOOD.}

This is the most paying condiment or melicated food ever given to calves, fattening cattle, cows, horses and hogs. It is prepared from roots, herbs, barks and seeds, and cures and prevents disease, insuring health and rapid growth for all young stock. It is not a purely fattening food to be like corn, meal, etc., but to be added to the regular feed of grain, because it will stimulate and permanently strengthen the digestive organs, so that each animal will obtain more nourishment from the grain eaten. With every 25 -1b. pail we give free a copy of the International Stock Food Co.'s Stock Book, which gives complete information in regard to many accidents and diseases that your stock are liable to have at any time.

\section{PRICES.}

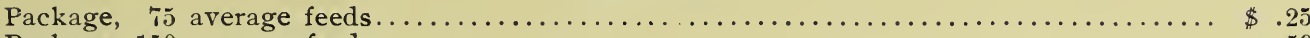

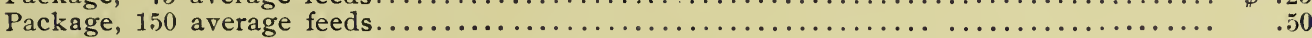

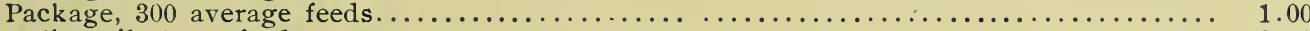

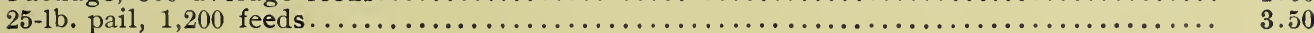

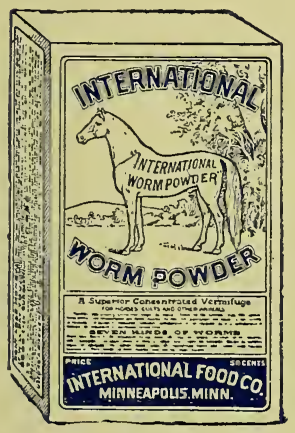

\section{INTERNATIONAL WORM POWDER.}

International Worm Powder is a perfectly harmless tonic and vermifuge and will do your horse good whether he has worms or not. If he does not have worms International Worm Powder will invigorate the digestive organs, purify the blood and tone up the system. Price $50 \mathrm{cts}$. per pkg.

\section{INTERNATIONAL SILVER PINE HEALING OIL.}

Silver Pine Healing Oil is composed of pure vegetable healing oils and if applied at once after an injury it absolutely prevents any serious inflammation and causes the wound to heal with remarkable rapidity. It also cures old sores, bruises, kicks, swellings, burns, scalds and all flesh wounds. Price, per bottle, 50 cts.

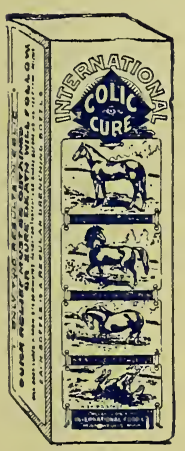

\section{INTERNATIONAL COLIC CURE.}

International Colic Cure is prepared from ten ingredients which are selected with great care in order to have them of strictly highgrade quality. It is anti-spasmodic and almost instantly neutralizes the gases and stops the fermentation of food. The manufacturer

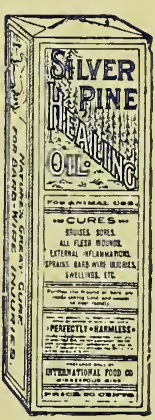
guarantees it not to fail. Price, per bottle, $50 \mathrm{cts}$.

\section{INTERNATIONAL GALL CURE.}

This is an easy and pleasant remedy to use, and a quick and a sure cure for galls, sore shoulders, sore necks, backs and mouths; also for cuts, bruised heels, etc. It cures while your horses are at work or rest. Full directions with each box. Price 25 and $50 \mathrm{cts}$.

\section{INTERNATIONAL HEAVE CURE.}

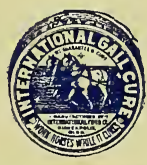

This is a strictly vegetable medicine and gives remarkable results when used as directed. It can be given to horses in perfect safety, and is guaranteed free from mineral and poisonous ingredients. It is not only a sure remedy for heaves but it has tonic effect on the entire system. Price, per pkg., 50 cts.

\section{INTERNATIONAL HONEY-TAR FOOT REMEDY.}

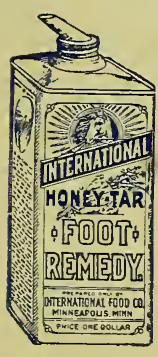

International Honey-Tar Foot Remedy is prepared from strained honey, pine tar and other ingredients and is a perfect horse foot remedy.

It is a remarkable foot grower, softener and toughener, and is recommended for nail wounds, scratches, thrush, coras, quarter cracks and contracted feet. Price, per can, $50 \mathrm{cts}$.

\section{INTERNATIONAL POULTRY FOOD.}

The special purpose of International Poultry Food is in promoting good health. It purifies the blood, stimulates the appetite and insures a strong, active body. It is an invaluable food for moulting fowls. It prevents disease and increases the egg production. The manufacturers guarantee that it cannot be fed to hens at any time during winter or summer without showing a large increase in eggs, if directions are followed.

PRICES.

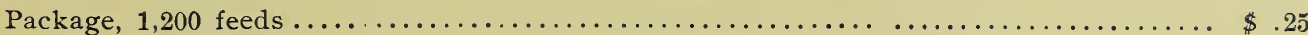

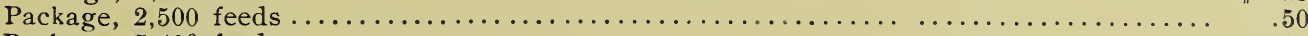

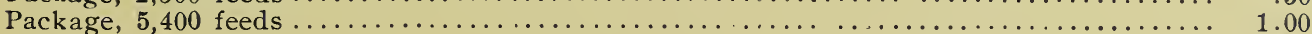

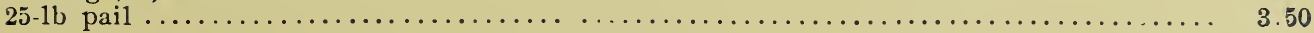




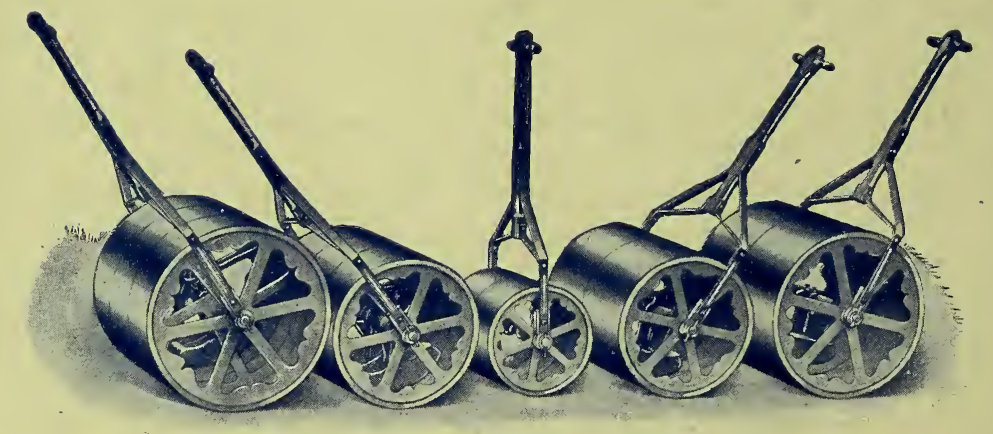

